\title{
"His Garden a Wilderness" - the balance between equality and freedom of religion in Australia and Canada
}

\author{
Eliza Kate Bateman \\ Faculty of Law \\ McGill University, Montreal
}

A thesis submitted to McGill University in partial fulfillment of the requirements for the degree of Master of Laws

15 August 2014

(c) Eliza Bateman, 2014 


\begin{abstract}
This thesis analyzes Australian and Canadian approaches to rights conflict focusing on challenges between freedom of religion and equality in public life. The first section involves an historical and doctrinal analysis of rights frameworks in Australia and Canada and a comparative analysis of cases that test public boundaries of freedom of religion and equality. This section concludes that the Australian framework is an imperfect mechanism for resolving disputes about freedom of religion. A comparison to the Canadian framework demonstrates that principles of reconciliation and limitation of rights provide a more satisfying answer to challenges between religious freedom and equality rights. The argument put in the second section is that both states assert freedom of religion and equality as fundamental rights but in fact their competing scope remains unresolved. The second section applies political theory to the question of freedom of religion, building on the presumption that neither Australia nor Canada (as modern liberal states) has agreed an agreed public 'place' for religion. This thesis proposes a theoretical solution of adopting a more inclusive definition of religion within an egalitarian liberalism framework and prefers the test of 'ethical independence' proposed by Ronald Dworkin for responding to claims of religious expression rather than a 'special rule' or exemption approach.
\end{abstract}

Cette thèse a pour objet la comparaison des approches australienne et canadienne du conflit entre la liberté de religion et l'égalité dans la vie publique. La première section est une mise en perspective historique et doctrinale des cadres juridiques australien et canadien ainsi qu'une analyse des cas qui ont questionné les limites de la liberté de religion et le droit à l'égalité. En conclusion de cette section, je démontrerais l'insuffisance du cadre juridique australien pour la résolution des conflits autour de la liberté de religion. La comparaison avec le droit Canadien démontre que les principes de réconciliation et de limitation des droits permettent de résoudre le conflit entre la liberté de religion et le droit à l'égalité. L'argument avancé dans la seconde section est que les deux États reconnaissent la liberté de religion et le droit à l'égalité comme droits fondamentaux, mais que dans les faits leur étendue demeure incertaine. La seconde section discutera de la liberté de religion dans le prisme de la théorie politique, ceci en se fondant sur l'hypothèse que ni l'Australie ni le Canada (en tant qu'états libéraux modernes) n'ont pas d'espace public pour la religion. Cette thèse propose une solution théorique d'adoption d'une définition qui inclut la religion dans le cadre de référence-cadre égalitaire libérale et utilise le test de 
"l'indépendance éthique" proposé par Ronald Dworkin afin de répondre aux requêtes de liberté d'expression religieuse plutôt qu'une approche par exemption ou "règle dérogatoire particulière". 


\section{TABLE OF CONTENTS}

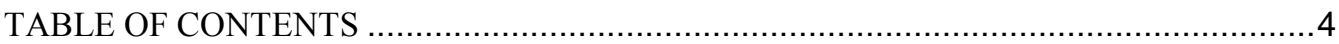

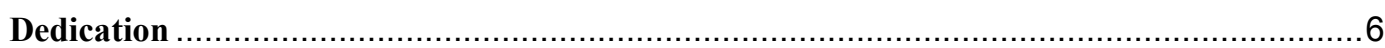

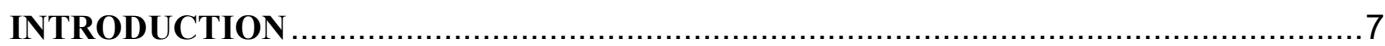

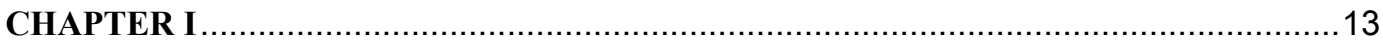

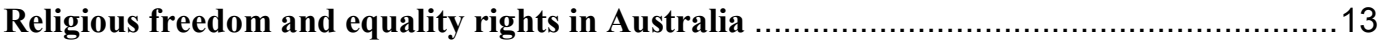

I Situating freedom of religion and equality rights in Australia .......................................14

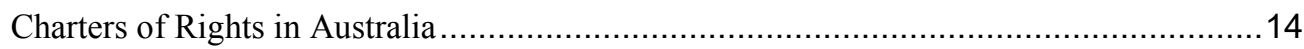

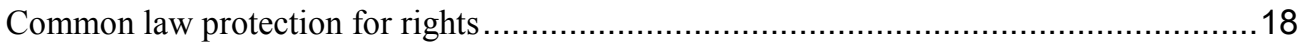

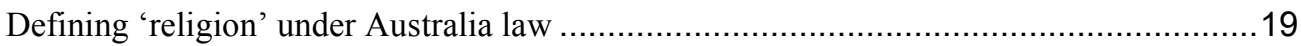

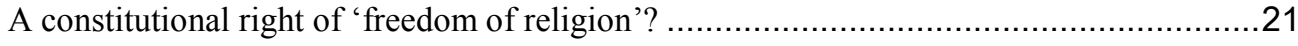

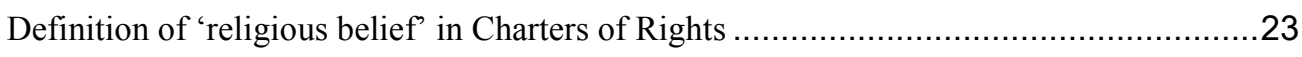

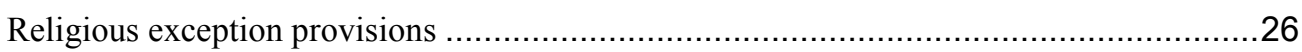

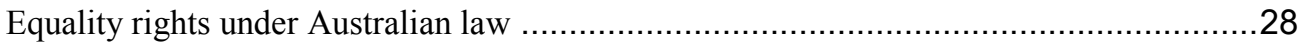

Conflict of rights: discrimination law as a balancing framework …............................2. 29

'Protect religious freedom': a task for equality frameworks? ..........................................30

II An Australian judicial approach to rights reconciliation: Cobaw ....................................33

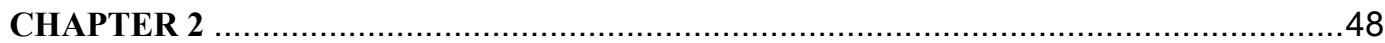

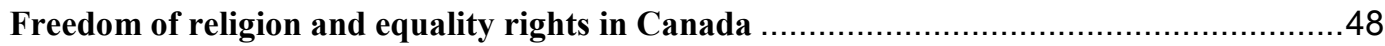

Rights protection frameworks in Canada .......................................................... 48

Scope of rights: Freedom of religion, conscience and belief .....................................53

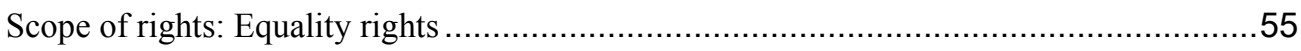

General principles for resolving rights conflict: overview ........................................58

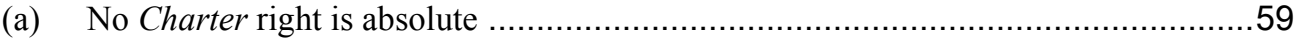

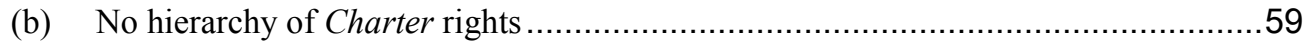

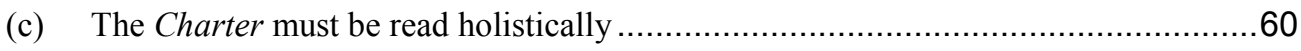

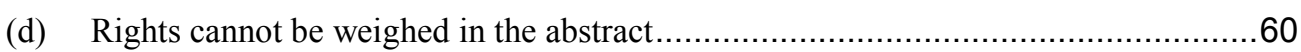

(e) Courts should balance relevant rights with applicable societal values ....................61

(f) 'Core' of a right is more protected than its periphery .........................................62

(g) Respect importance of both sets of rights at play .............................................63

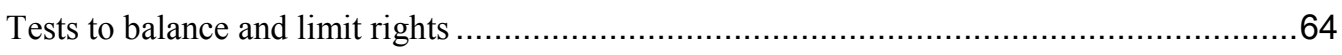

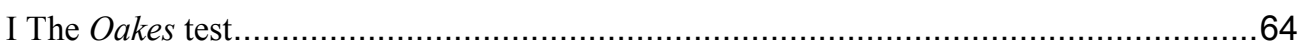

II 'Reconciling' approach to achieving a resolution of rights ........................................66

III Analysis: differences between the Oakes and Dagenais frameworks.........................67

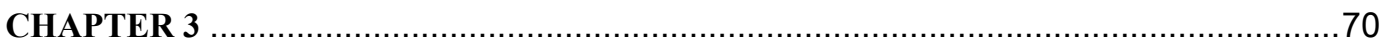

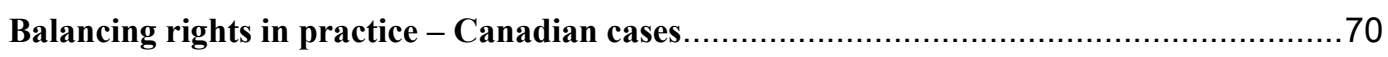




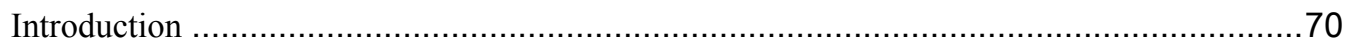

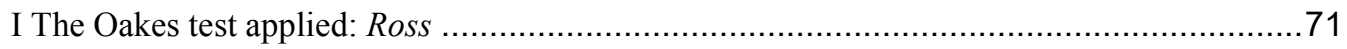

Scoping the rights at play: a breach of freedom of religion .......................................... 73

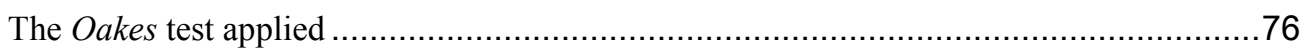

Commentary on the application of the Oakes test in Ross .........................................79

II The Dagenais framework for reconciling individual rights 'conflict': Trinity Western .........82

Conflict of rights issue - the Dagenais framework applied .......................................... 83

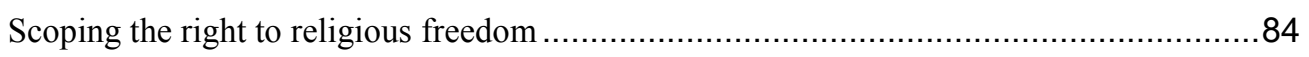

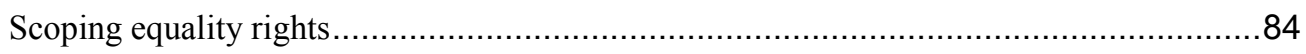

Reconciling rights in context: line between belief and conduct ....................................86

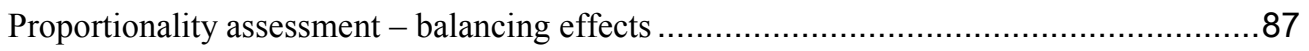

Dissenting judgment: the Dagenais approach critiqued .......................................... 87

Analysis: the approaches in Ross and Trinity Western and the impact on freedom of religion

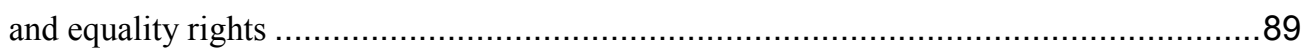

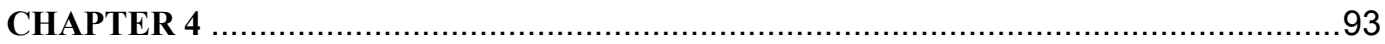

A theoretical perspective of freedom of religion in Australia and Canada ..........................93

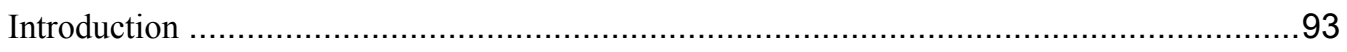

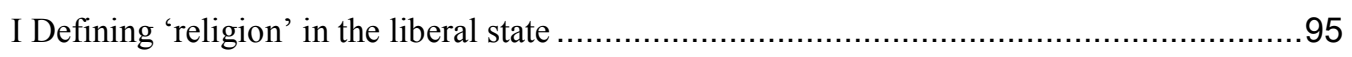

Egalitarian liberalism and freedom of religion .................................................. 102

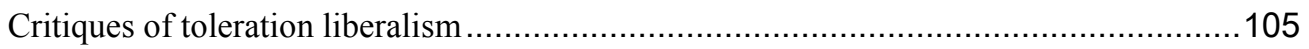

Challenges to egalitarian liberalism and a new definition of religion - a libertarian view of

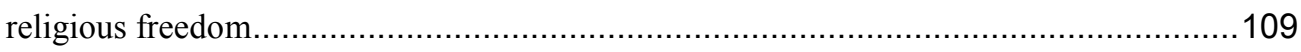

II A test for religious expression in public life - ethical independence..............................112

Dworkin's 'general rule' approach - the best answer to a difficult question ...................116

Public space and religion - specific issues - anti-discrimination and sexual orientation ...120

Applying the ethical independence framework in practice .........................................121

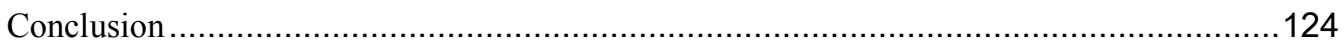

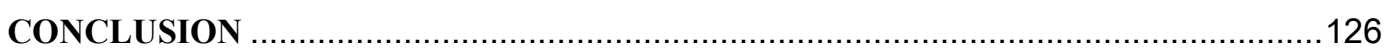

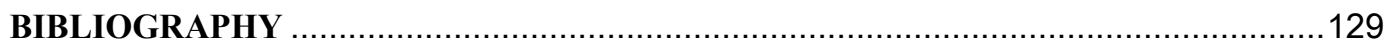




\section{Acknowledgements}

First, I wish to thank my supervisor, Professor Daniel Weinstock for his invaluable advice and support throughout this project; and for introducing me to great thinkers who brought some clarity to a difficult topic. I could not have had a more inspiring supervisor. Thanks also to Professor Angela Campbell for giving me the opportunity to write a thesis back when I started the L.L.M program.

Second, thank you to all the great people who inspired me to write about religion and equality: everyone at the Victorian Equal Opportunity and Human Rights Commission and the Equality Law Program at Victoria Legal Aid. Particular mention must be made of the excellent Emma Turner and the incomparable Skye Rose.

Lastly, to everyone who has supported me in so many ways over the last year. I owe you so many thanks and so much love: Clara Bateman, Peter Hazlehurst, Yuriko Hazlehurst, Guillaume Beal, Anne Iavaronne-Turcotte, Marion Rebière, Maddy Conway, Ghyslain Raza, Fiona Atkin, Eleanor Ashton, Caitlin Bessell, Lucy Hoult and Aaron Schurink.

\section{Dedication}

This is for my dad. 


\section{INTRODUCTION}

I first developed an interest in the relationship between freedom of religion and equality rights while working as a legal adviser at the Victorian Equal Opportunity and Human Rights Commission (Victorian Commission). In 2010 - 2011, we had a growing caseload of discrimination complaints against religious bodies on the basis of sexual orientation, pregnancy and marital status. Part of my role was to offer legal advice to conciliators and mediators about the conflict of rights issues in these cases and the potential scope of the 'right of religious freedom', applying religious exceptions to general equality guarantees in state human rights legislation.

One complaint we received was brought by a community group (Cobaw Community Health) against a commercial entity owned and operated by the Exclusive Brethren Church of Australia (Christian Youth Camps (CYC)). CYC had refused to allow a group of youth volunteers to rent out a campsite on the basis that it disagreed fundamentally with the ethos of the camp: to develop strategies for suicide prevention and awareness raising of mental health issues for gay and lesbian teenagers. This case did not resolve at conciliation and was heard by the Victorian Civil and Administrative Tribunal ${ }^{1}$ and then appealed to the Victorian Court of Appeal. ${ }^{2}$ Cobaw was successful at both instances, however the case is presently on appeal to the High Court of Australia. $^{3}$

The Victorian Commission has intervened in both proceedings to date: providing submissions on the question of resolving a conflict of rights and the prospective scope of religious exception provisions in anti-discrimination legislation, taking into account international human rights principles and the operation of the Victorian Charter of Rights and Responsibilities Act. ${ }^{4}$ While preparing submissions, our team canvassed the shortfalls of the Australian framework for protecting rights and reconciling disputes between equality and freedom of religion. We

\footnotetext{
${ }^{1}$ Cobaw Community Health Services v Christian Youth Camps Ltd \& Anor [2010] VCAT 1613 [Cobaw VCAT].

${ }^{2}$ Christian Youth Camps Ltd $v$ Cobaw Community Health Ltd and Victorian Equal Opportunity and Human Rights Commission and Attorney-General for the State of Victoria [2014] VSCA 75 [Cobaw].

${ }^{33}$ Katherine Towers, "Appeal to clarify religious standing", The Australian 23 May 2014, online: http://www.theaustralian.com.au/business/legal-affairs/appeal-to-clarify-religious-standing/story-e6frg97x$1226927433470 ? \mathrm{nk}=$ fbfeb6feac38bb1971bcf0d33bd01846

${ }^{4}$ Charter of Human Rights and Responsibilities Act 2006 (Vic) [Victorian Charter].
} 
researched international law and tests for rights balancing in comparative jurisdictions, although (in my view) we did not give sufficient consideration to aspects of the Canadian model. This was a pity, as the research for this project has demonstrated that there are many advantages to the Canadian rights framework that could be adopted in Australia, even allowing for the lack of a constitutional Charter of Rights.

My experiences throughout the Cobaw litigation was that disputes about equality and religion are bitterly fought on both sides, with greater philosophical divides between the parties than is usual in discrimination cases. This is because both positions present a fundamentally different conception of what it means to be treated with dignity in public life and to enjoy fundamental freedoms. I also realised that my experience of finding these issues difficult to resolve was not isolated. The Tribunal decision in Cobaw runs to 83 pages and the Court of Appeal judgment runs to 197 pages. The Victorian Court of Appeal reconvened the parties for further oral submissions on the conflict of rights question (among other issues) on 2 August 2013, six months after the initial two day appeal hearing on $20-21$ February 2013. The Court also accepted amicus briefs from the International Commission of Jurists and the Ambrose Centre for Religious Liberty Ltd on the question of the proper scope and interpretation of the right of religious freedom and equality rights. ${ }^{5}$

I do not intend to defend the position that the Victorian Commission took in the Cobaw litigation in terms of reaching 'one agreed position' for resolving a conflict of rights in this work. Rather, I want to test the Australian equality framework (and my previous conclusions about the limitations of that framework) against the Canadian approach to rights conflict and critically compare how similar issues have been resolved. This is the background work that informed this investigation. Hopefully it provides some clarity as to why I chose to limit my case analysis to those that deal precisely with concerns about an 'equality agenda' and with opposing concerns that religious freedom operates as a discriminatory and negative social force in the public sphere. The category of cases that I analyse demonstrate significant anxieties about the role of religion

\footnotetext{
${ }^{5}$ International Commission of Jurists, Amicus Curiae Submissions, 17 August 2012, available at: http://icj.wpengine.netdna-cdn.com/wp-content/uploads/2014/04/221000080 17 Submissions-ICJ-amicus-curiaeapplication-17-August-20....pdf (last accessed 2 August 2014). The Ambrose Centre amicus brief is not publicly available.
} 
and equality in areas of public life such as education and employment. These are cases which constitute formal breaches of equality guarantees: where there is an explicit refusal or discriminatory treatment of a group on the basis of a protected characteristic, by reason of the enjoyment of religious freedom.

In this thesis, I make two discoveries on the basis of two different lines of inquiry. The first is a comparison between the Australian and Canadian approaches to rights limitation/reconciliation. Through a doctrinal analysis of these two rights frameworks, I argue that the Canadian tests for resolving rights conflict are to be preferred to the statutory interpretation model favoured in Australia, although there are of course significant political and constitutional hurdles in the way of the adoption of these tests or principles in Australia.

In Chapter 1, I analyse the Australian history of rights protection and different views about whether or not Australia should adopt a uniform approach to human rights legislation as opposed to the current piecemeal protections provided by anti-discrimination legislation, the common law, and (to some limited extent) international human rights principles. In the second part, I present a close critique of the Victorian Court of Appeal's decision in Cobaw, ${ }^{6}$ and argue that, although the Court made a genuine attempt to bring clarity to the question of balancing equality rights and religion in public life, its decision is overly technical and lacks the cohesion and consistency of comparable Canadian decisions. I conclude however, that this is the inevitable result of a rights protection framework that has no dedicated mechanism to balance and (where necessary) limit rights.

In Chapters 2 and 3, I analyse the Canadian approach to human rights interpretation, with a focus on jurisprudence where courts have been asked to balance equality rights or values with freedom of religion. I outline the different principles and tests that operate to determine a conflict of rights, with a focus on (a) the Oakes test to determine whether section 1 of the Charter of Rights and Freedoms ${ }^{7}$ applies where there is a challenge of Charter rights and (b) the more recent

\footnotetext{
${ }^{6}$ Cobaw, supra note 2.

${ }^{7}$ Canadian Charter of Rights and Freedoms, Part 1 of the Constitution Act, 1982, being Schedule B to the Canada Act 1982, (UK), 1982, c. 11 [Charter].
} 
approach of rights 'reconciliation', where the rights of two parties appear to conflict, developed by the Supreme Court of Canada in Dagenais v Canadian Broadcasting Corporation. ${ }^{8}$

In Chapter 3, I provide detailed analysis of two equality/religion decisions where the Supreme Court of Canada applied the two reconciliation/limitation tests. I draw conclusions about the similarities between the tests for rights limitation and reconciliation and highlight their strengths, in terms of providing a clear framework for assessing rights claims and a nuanced approach to assessing the relevant contexts of rights conflict in particular cases. However, I also express doubt about the success of the 'reconciliation of rights' approach from the perspective of offering a practical outcome to parties. I suggest that, in fact, there are few equality rights/religious freedom challenges where a court's determination that there is no conflict of rights to resolve, as both sets of rights can be appropriately reconciled, will be satisfactory. In many of the cases presented in this thesis, courts should acknowledge that there is in fact a 'rights trump' outcome, however the principles of rights resolution are presented.

In Chapter 4, I draw together the lines of inquiry and critique raised in the preceding analysis and present my second key argument: that there are foundational questions about the legitimate role of religion and religious expression that go beyond legal tests of rights limitation and relate to our fundamental conception of rights in the modern liberal state. In this chapter, I therefore apply a liberal theoretical framework to the conflict of rights debate in Australia and Canada to see whether a new scope for religious expression in public could assist in determining rights conflict between religious freedom and equality.

I analyse two issues that recur with increasing frequency in judicial engagement with the equality-religion issue and that were the focus of the cases analysed in this work: (a) the question of when and how to protect religious expression in the public square where this expression challenges equality rights and (b) the question of how a state should assess freedom of religion claims: are they still a 'special right' or could we approach religious expression claims from the perspective of one aspect of a general right to 'ethical independence'?

\footnotetext{
${ }^{8}$ Dagenais v Canadian Broadcasting Corporation [1994] 3 S.C.R. 835, 120 D.L.R. (4th) 12 [Dagenais].
} 
In responding to these questions, I consider arguments for and against egalitarian liberalism and toleration liberalism, and I analyse Ronald Dworkin's proposal for a broadened definition of religion and a revised role for religion within the egalitarian liberal state as one aspect of ethical choices that people make. Then, I consider a theoretical resolution to the issue of the degree of legitimacy of religious expression in the public square. In conclusion, I advocate for a strong egalitarian liberal state position, with allowances made for mandatory requirements of faith and religious practice that satisfy a reasonably high bar. Where this bar is not met, liberal principles of equality and non-discrimination should inform state legislative choices, provided these operate within an area of public life that is generally subject to regulation.

I have chosen to focus on these issues because I find that the legal analysis in the cases discussed in the preceding chapters does not resolve them. Further, these questions should not be seen necessarily seen as a failure of the rights adjudication systems in Australia and Canada, but rather seen more broadly as issues for political and rights theory to address. I contend that we have not arrived at a social or cultural consensus about the significance of religion in public life, and as new, competing norms evolve within liberal societies (such as the extension of the definition of equality rights to encompass gay, lesbian, transgender and intersex sexual orientation), our rights reconciliation processes are continually tested by religious freedom claims.

There are some limitations to my analysis that I concede from the outset. I have deliberately narrowed my line of inquiry to exclude cases where more private aspects religious observance have implications for equality guarantees; for example, the difficult gender equality issues that arise in some conservative religious communities, or the challenge of providing a meaningful right of exit for gay or lesbian religious adherents. I limited my investigation in this way to enable a more detailed analysis of the place of religion in the public square and how it interacts with equality rights of non-group members.

However, as I acknowledge in my conclusion, there are many other, troubling points of intersection between equality rights and freedom of religion that warrant further investigation, particularly if one argues (as I do) that a strong right to freedom of association must operate in the liberal state to protect minority group rights. My conclusions about the balance between liberal values and freedom of association may therefore change if the focus of this work was on 
internal members of religious communities rather than the engagement with the non-religious 'other' in public space. However, religious belief in the private sphere is not the focus of this study. My focus is the balance of rights in what is agreed (generally) to be the public square and specifically in those areas where the state can legitimately regulate. 


\section{CHAPTER I}

\section{Religious freedom and equality rights in Australia}

In this chapter I analyse conflict between equality rights and the freedom of freedom of religious expression in Australia. The first part involves an introductory discussion of the scope of religious freedom rights and equality rights under Australian law. However, given the unique and complex nature of Australia's rights protection model, I will also present some of the argument for and against the codification of rights protection in Australia, with particular focus on anxieties of religious groups. I also (briefly) discuss the proposed 'human rights based approach' to rights protection in Australia, with emphasis on the consolidation of federal equality laws project and the Victorian Charter,${ }^{9}$ the first state human rights Act in Australia.

The second part of this chapter is a detailed case analysis of the decision of the Victorian Court of Appeal (Court of Appeal) in Christian Youth Camps Ltd v Cobaw Community Health Ltd. ${ }^{10}$ The Court of Appeal's judgement is the most complex decision on freedom of religion and equality protection provided by an Australian superior court to date. It situates the arguments and challenges for rights conflict resolution foreshadowed in the first part. I conclude my analysis of Cobaw with some targeted criticism of the Australian rights protection model and the Court of Appeal's means of resolving rights conflict.

I do not intend to merely provide a comparative analysis between the Australian and Canadian models of rights protection and rights reconciliation. This work takes as its starting point the fundamental differences between the two systems, notably the lack in Australia of a constitutional bill of rights. However, in this first chapter, I criticise the Australian approach to religious freedom as failing to either (a) adopt a jurisdiction specific model rights limitation and reconciliation that goes beyond statutory interpretation principles, as done by Canada or (b) adopt the international human rights approach to scoping rights as recommended by human rights

\footnotetext{
${ }^{9}$ Victorian Charter, supra note 4.

${ }^{10}$ Cobaw, supra note 2 .
} 
commissions in Australia. ${ }^{11}$ The application of the Australian model in Cobaw is then tested, beside two decisions of the Supreme Court of Canada, against a theoretical rights framework in chapter four and a new definition of religious freedom and more fundamental engagement with liberal rights theory is advocated. This later analysis emphasises the relative similarities in limitation and effect between the Australian and Canadian rights balancing models rather than their differences. Therefore, there are different theoretical critiques of the Australian approach applied to the discussion in this Chapter.

\section{Situating freedom of religion and equality rights in Australia}

\section{Charters of Rights in Australia}

The legal human rights environment in Australia is unique, as it is the only western nation to operate without either a constitutional charter of human rights or a federal human rights statute. ${ }^{12}$ The human rights debate in Australia is therefore at a more fundamental stage compared to other Westminster jurisdictions and discussion about conflicts between rights in Australian society are often obscured by positional arguments about whether or not constitutional protection for rights is 'necessary' to maintain the balance between individual liberties and collective rights. Debate about the best mechanism to protect civil and political rights such as freedom of religious expression and equality rights is therefore heavily influenced by the question of whether Australia should entrench rights in a constitutional form or whether existing legislative and common law protections are sufficient to constitute a rights framework.

The rights debate in Australia has intensified in the last decade following campaigns for the federal government to recognise same-sex marriage and prohibit discrimination on the basis of sexual orientation and gender identity, ${ }^{13}$ public inquiries into significant increases in hate speech

\footnotetext{
${ }^{11}$ Australian Council of Human Rights Agencies, Submission to the Consolidation of Commonwealth AntiDiscrimination Acts, 1 February 2012, online: http://www.humanrightscommission.vic.gov.au/index.php/submissions/item/192-achra-submission-todiscrimination-law-consolidation-project-feb-2012

${ }^{12}$ David Erdos 'Elite 'blockages' and the failure of national Bill of Rights initiatives in Australia: A comparative Westminster analysis" 200846 Commonwealth \& Comparative Politics 3 published online: doi:10.1080/14662040802176566 (http://dx.doi.org/10.1080/14662040802176566) (last accessed: 17 July 2014 ).

${ }^{13}$ Recent amendments to the Sex Discrimination Act 1984 (the Sex Discrimination Amendment (sexual orientation) Act 2012 introduced 'sexual orientation and gender identity' as protected attributes under federal law. An attempt to legislate for same-sex marriage in the Australian Capital Territory was struck down by the High Court of Australian in 2013: Commonwealth of Australia v The Australian Capital Territory [2013] HCA 55. The High Court unanimously held that the Marriage Equality (Same Sex) Act 2013 (A.C.T.) was inconsistent with the federal
} 
racism and religious vilification ${ }^{14}$ and a self-titled 'libertarian rights push' by conservative media, ${ }^{15}$ Christian rights advocates and conservative politicians to address an alleged overreach of 'unelected judges and liberal human rights commissions' in the application of antidiscrimination law to religious activity and proposals to extend the application of federal human rights legislation to increase coverage, including introducing sexual orientation and gender identities as protected attributes under federal human rights Acts. ${ }^{16}$

The Australian government called for a review of the federal anti-discrimination statutes in 2010, with a view to consolidating the five Acts into one omnibus 'human rights Act'. The consolidation process involved a wide-ranging public consultation process and the unusual step of the Attorney-General's Department releasing the exposure draft of the Human Rights and AntiDiscrimination Bill 2012 (HRAD Bill) for further public comment in November 2012, prior to hearings before the Legal and Constitutional Committee of the Australian Senate. The Majority Report of the Senate Committee recommended the Bill be passed. ${ }^{17}$ The only legislative amendments that survived this process were amendments to the Sex Discrimination Act 1984 (Cth) to introduce 'sexual orientation' and 'gender identity' as protected attributes under Commonwealth law. However, political pressure from lobby groups, including conservative religious groups, led the government to abandon the Bill. Coalition Senators for the Senate Committee summarised the opposition position to the Bill in their minority report; stating that the

\footnotetext{
Marriage Act 1961 (Cth) [Marriage Act] and as federal Parliament has constitutional power to legislate with respect to same sex marriage, the ACT legislation was wholly invalid.

${ }^{14}$ Victorian Equal Opportunity and Human Rights Commission, Reporting Racism, What you Say Matters, (Report, 2012) online:

http://www.humanrightscommission.vic.gov.au/media/k2/attachments/Reporting_Racism_Web_low_res.pdf (last accessed: 27 June 2014).

Australian Human Rights Commission, Racism, It Stops With Me: and the national anti-racism strategy one year on, (Report and Action Plan, 2012), online: https://www.humanrights.gov.au/sites/default/files/document/publication/WEB_RISWM_one year_on_report $\% 20 \mathrm{fi}$ nal.pdf (last accessed: 27 June 2014).

${ }^{15}$ See: Andrew Bolt, "Marcia Langton's vilification: no law against this kind of abuse”, 11 March 2004, Herald Sun online, available at:

http://blogs.news.com.au/heraldsun/andrewbolt/index.php/heraldsun/comments/marcia_langtons_vilification_no_law against this kind_of abuse/ (last accessed: 20 May 2014).

${ }^{16}$ See: Coalition Senators' for the Senate Legislative and Constitutional Affairs Committee, Minority Report: Human Rights and Anti-Discrimination Bill 2012, (December 2012), at 8 [Minority Report].

${ }^{17}$ Australian Senate Legislative and Constitutional Affairs Committee, Majority Report: Human Rights and AntiDiscrimination Bill 2012 (December 2012) at 3-4.
} 
Bill did not protect libertarian rights such as freedom of expression and freedom of religion and was merely an attempt to strengthen equality rights: ${ }^{18}$

[T]his Bill is not, in truth, an anti-discrimination law at all. It is an attempt to use the guise of anti-discrimination to advance a much more ambitious and intrusive social agenda, in which the role of the state as the arbiter not just of legality, but of the norms of everyday conduct, would be massively expanded... This is a nightmarish dystopia which only Kafka could have imagined. ${ }^{19}$

There has been significant academic attention paid to the question of whether Australia should or could introduce a constitutional bill of rights or even a federal human rights Act granting the judiciary powers to review legislation and government action from the perspective of rights. ${ }^{20}$ The history of attempts to codify human rights' protections in Australia demonstrates that the question of a constitutional protection for human rights is political rather than legal and, for the time being at least, has been firmly answered in the negative. ${ }^{21}$

One Australian state (Victoria) and one Australian territory (the Australian Capital Territory) (A.C.T) have introduced statutory charters of rights. ${ }^{22}$ However, the operation of these statutes is relatively limited. ${ }^{23}$ By their design, they apply only to actions of government and public authorities within specific state and territory jurisdictions (so have no application to federal law), do not constrain parliamentary sovereignty and, in the case of the Victorian Charter, the role of the judiciary in recommending to parliament that legislation is rights-infringing has been limited by the High Court. ${ }^{24}$

\footnotetext{
${ }^{18}$ Minority Report, supra note 18 at 8.

${ }^{19}$ Ibid.

${ }^{20}$ See: Andrew Byrnes, Hilary Charlesworth and Gabrielle McKinnon, Bills of Rights in Australia, history, politics and law, (Sydney, University of New South Wales Press, 2009), at 23 - 43; Tom Campbell, Jeffrey Goldsworthy and Adrienne Stone, Protecting rights without a bill of rights, institutional performance and reform in Australia (Aldershot, Ashgate Publishing Limited, 2006).

${ }^{21}$ The last national investigation into a potential human rights framework was concluded in 2010, when Father Frank Brennan was tasked with reporting on the current appetite for human rights reform at the national level and proposed legislative changes to anti-discrimination statutes. The Terms of Reference for the Brennan Inquiry were limited by executive direction by the Prime Minister that a constitutional charter of rights was not to be included in the Terms of Reference for the Inquiry and was not to be a proposal included in the Brennan Report.

22 Victorian Charter, supra note 4; Human Rights Act 2004 (A.C.T.).

${ }^{23}$ Caroline Evans, Australian Bills of Rights: The Law of the Victorian Charter and ACT Human Rights Act (Melbourne, LexisNexis, 2008); George Williams, "The Victorian Charter of Human Rights and Responsibilities: Origins and Scope" 2006, 30, Melb. U.L.Rev. pp. $880-905$.

${ }^{24}$ Momcilovic v The Queen (2011) 280 ALR 221 (Momcilovic).
} 
Both the A.C.T and Victorian Charters include a general limitations provision to manage conflict of rights and conflicts between rights and other values. Section 7(2) of the Victorian Charter was consciously modelled on section 1 of the Canadian Charter:

A human right may be subject under law only to such reasonable limits as can be demonstrably justified in a free and democratic society based on human dignity, equality and freedom, and taking into account all relevant factors including:

(a) the nature of the right; and

(b) the importance of the purpose of the limitation; and

(c) the nature and extent of the limitation; and

(d) the relationship between the limitation and its purpose; and

(e) any less restrictive means reasonably available to achieve the purpose that the limitation seeks to achieve.

Australian courts have expressed considerable hesitation about the applicability of general limitation provisions in cases where a conflict has arisen between a right and a legislative purpose or conflicting right, and the future of general limitations provisions in terms of resolving a conflict of rights is, at best, uncertain. In $R v$ Momcilovic, ${ }^{25}$ the first High Court decision on the constitutionality of the Victorian Charter, each member of the Court provided a separate judgement to address the constitutionality questions, including the question of where and when a rights limitation analysis should interact with the requirement to interpret legislation consistently with human rights (in that case, the right to the presumption of innocence). ${ }^{26}$

In Momcilovic, a plurality of the High Court ${ }^{27}$ accepted that section 32(1) of the Victorian Charter was constitutionally valid, but on the basis that it was to operate as merely one of the 'normal rules of statutory construction' that assists courts to find the 'plain meaning' of a provision and, except where there is express legislative intent to the contrary, to read this provision consistently with human rights obligations. ${ }^{28}$ In terms of the scope of religious freedom provisions in state statutes, both human rights commissions and religious organisations have contended that this finding should enable a court to have reference to international legal

\footnotetext{
25 Ibid.

${ }^{26}$ Victorian Charter, supra note 4, section 32(1) provides: "so far as it is possible to do so consistently with their purpose, all statutory provisions must be interpreted in a way that is compatible with human rights."

${ }^{27}$ French CJ, Gummow, Hayne, Crennan, Kiefel and Bell JJ.

${ }^{28}$ Victorian Attorney-General's Solicitors Office, "Official Case Note, Momcilovic v The Queen [2011] HCA 34" (8 September 2011) at 4.
} 
principles when interpreting terms such as 'religious freedom' and 'religious expression'. However, in later judgments following the High Court's decision in Momcilovic, the Victorian Court of Appeal was forced to conclude that the High Court judgments were so badly split on the question of when and how the general limitations clause should be applied (in terms of providing meaningful guidance to a section 32 analysis when two competing rights or values were engaged), that there was, in fact, no ratio for courts to apply. ${ }^{29}$

Such judicial uncertainty about the application of human rights limitation provisions demonstrates a greater reluctance in Australian parliaments and the judiciary to embrace human rights principles when interpreting legislative provisions or accepting a human rights framework as guiding principles in relation to rights limitation. As will be demonstrated in the second part of this chapter, Australian courts are more comfortable applying traditional principles of statutory interpretation to balance rights in conflict rather than human rights principles such as those adopted by the Canadian courts.

\section{Common law protection for rights}

In this uncertain legal environment, much is made of existing 'common law' rights protections that exist by virtue of common law presumptions and interpretative principles. Common law rights commonly cited as providing 'base legal protections' for rights include the right to habeas corpus, the right to the presumption of innocence, the principle of legality in statutory interpretation and private property rights. ${ }^{30}$ However, common law rights are of limited effect, as they may be excluded or read down by the operation of legislation. For example, in 2005, the federal government introduced the Anti-Terrorism Act 2005 (Cth) that removed the right of habeas corpus to people charged with 'terrorism offences' 31 and introduced control and detention orders which enabled the Australian Federal Police to detain suspects for up to 10 days in a

\footnotetext{
${ }^{29}$ Slaveski v Smith \& Anor [2012] VSCA 25 at 20; Noone v Director of Consumer Affairs Victoria v Operation Smile (Australia) Inc. \& Ors [2012] VSCA 91 at 29.

${ }^{30}$ See: His Honour Chief Justice French, "The Common Law and the Protection of Human Rights", Speech to the Anglo Australasian Lawyers Society, 4 September 2009.

${ }^{31}$ Anti-Terrorism Act 2005 (Cth), section 3.
} 
federal prison without charge (thereby explicitly excluding habeas corpus or the right to presumption of innocence). ${ }^{32}$

Significantly, Australia has not systematically incorporated international treaty obligations directly into domestic law by operation of a Charter of rights. Rather, it is a central principle of Australian constitutional law that the obligations of an international treaty do not form part of Australian domestic law until they have been incorporated in valid domestic legislation. ${ }^{33}$ International treaties therefore have an awkward 'supplementary' position in Australian law in the absence of a statutory bill of rights. ${ }^{34}$ The High Court has held that the text of international treaties may assist in the interpretation of ambiguous domestic law or in the exercise of statutory discretion, but this is as far as the treaties may assist in the absence of explicit legislative incorporation. ${ }^{35}$ The incorporation of international human rights principles under Australian law can therefore be described, at best, as piecemeal and limited.

\section{Defining 'religion' under Australia law}

One difficulty with resolving questions about the scope of religious freedom under Australian law is that there is no constitutional statement of what constitutes a 'religion' in Australian law, and therefore responsibility for determining the scope of the term has been left to the common law. The High Court of Australia first considered the question of what constitutes a religion and a religious body for the purposes of state taxation legislation in Church of the New Faith v Payroll Commissioner of Payroll Tax (Church of the New Faith). ${ }^{36}$

\footnotetext{
${ }^{32}$ Australian Human Rights Commission, A Human Rights Guide to Australia's Counter-Terrorism Laws, (2008), available online: https://www.humanrights.gov.au/human-rights-guide-australias-counter-terrorism-laws\#2 1 ${ }^{33}$ Walker v Baird [1982] AC 491; Victoria v Commonwealth (1996) 187 CLR 416.

${ }^{34}$ The Australian Human Rights Commission Act 1986 (Cth) [AHRC Act] Schedule A, includes a list of human rights conventions and treaties that inform its definition of 'human rights'. It has reporting functions that require it to investigate human rights abuses and issues within Australia and report to Parliament on these topics. However, the Commission does not have powers to enforce any of its recommendations and Parliament is not bound to respond to any report provided by the Commission.

${ }^{35}$ In Teoh v Minister for Immigration and Ethnic Affairs (1995) CLR 273, the High Court reviewed Australia's obligations as a signatory to Convention on the Rights of the Child (1989) United Nations Treaty Series, vol. 1577, p. $3[\mathrm{CROC}]$ and held that, even though Treaty articles had not been incorporated into Australian immigration law, where federal immigration law was ambiguous, a legitimate expectation might be created that administrative action by the federal government would be consistent with the CROC.

${ }^{36}$ Church of the New Faith $v$ Commissioner of Payroll Tax (Victoria) (1986) 154 CLR 120 [Church of the New Faith].
} 
In Church of the New Faith, the Court divided on the question of how to define a religion, although it unanimously held that Scientology was a religion under Australian law. The leading joint judgement is that of Acting Chief Justice Mason and Justice Brennan. Their Honours were not satisfied that the definition of religion required satisfying a purely subjective test of personal religious beliefs, nonetheless, they held that a narrow or technical definition would also not be acceptable. Their Honours reasoned that an objective criterion for religion was needed: one that could be universally applied across the acknowledged religions. ${ }^{37}$ Mason A-CJ and Brennan J concluded that a religion requires a belief in a supernatural being, thing or principle, and should not be limited to theistic concepts. ${ }^{38}$ Secondly, their Honours held that this belief must compel the "acceptance of conduct to give effect to that belief." 39

Bruce Kaye argues that the definition preferred by Mason A-CJ and Brennan J clearly goes beyond a theistic definition of religion, in that the core of the requirements is that the belief is something "that goes beyond the senses, its object is supernatural." ${ }^{40}$ Kaye is hesitant about the application of this broader definition of religion that appears to embrace fundamental personal beliefs beyond theism. What is clear, as Kaye observes, is that Mason A-CJ and Brennan J were of the view that there was a "need for such an apodictic Australian exposition" of religion and that their judgement intended to go beyond the context of the case and provide such a definition. ${ }^{41}$

In the second indicia, their Honours note the significance of religious practice in a definition of religion, as religion comprises not just religious beliefs but must include practices and conventions. Mason A-CJ and Brennan J held that "religious belief is not by itself a religion. Religion is also concerned at least to some extent with the relationship between man and a supernatural order... what man feels constrained to do or abstain from doing because of his faith in the supernatural is prima facie within the area of legal immunity, for his restriction would be

\footnotetext{
${ }^{37} \mathrm{Ibid}$, per Mason A-CJ and Brennan J at 132.

${ }^{38}$ Bruce Kaye, “An Australian Definition of Religion”, 1991, 14 U.NSW. L.J., pp. 331 - 351 at 335.

${ }^{39}$ Church of the New Faith supra note 36, per Mason A-CJ and Brennan J at 136.

${ }^{40}$ Kaye, supra note 38 at 335.

${ }^{41}$ Kaye, supra note 38 at 342 .
} 
impaired by restriction upon conduct in which he engages in giving effect to that belief."42 Kaye argues that the inclusion of religious conduct with religious belief demonstrates the majority's view that religion has its own personal and social life and must therefore have a 'recognised status within the framework of the law' as opposed to being merely a private right. ${ }^{43}$

The High Court's position on 'religion' under Australian law has remained largely unchanged and unchallenged since Court of the New Faith. Later decisions, notably the High Court's decision in Commissioner of Taxation of the Commonwealth of Australia $v$ Word Investments Ltd (Word Investments) ${ }^{44}$ determined the necessary relationship between religious purposes of an institution and its commercial activities in order to qualify for charitable (tax exempt) status under state law. Word Investments is relevant to this discussion to the extent that it informed the Court of Appeal's decision in Cobaw that a corporation owned by the Exclusive Brethren Church of Australia was not a 'body established for religious purposes'.

\section{A constitutional right of 'freedom of religion'?}

Religious freedom is protected in a limited sense by section 116 of the Australian constitution. ${ }^{45}$ However, section 116 has never been relied upon to justify or challenge the validity of antidiscrimination legislation that touches on the subject of religious freedom and religious expression. This is partly because section 116 has no application to Australian states or state law (and the majority of anti-discrimination statutes are state or territory statutes) ${ }^{46}$ and partly because the text of section 116 has been interpreted as limiting it to an establishment clause, ${ }^{47}$ or applying to laws that impose religious observance or prohibit the free exercise of religion. Anti-discrimination statutes, by comparison, are generally framed in rights-protective language that seeks to promote equality rather than limiting rights.

\footnotetext{
${ }^{42}$ Church of the New Faith, supra note 36 at 135.

${ }^{43}$ Kaye, supra note 38 at 350.

44 (2008) 236 CLR 204 [Word Investments].

${ }^{45}$ Commonwealth of Australia Constitution Act 1900 [Australian Constitution], section 116: The Commonwealth shall not make any law for establishing any religion, or for imposing any religious observance, or for prohibiting the free exercise of any religion, and no religious test shall be required as a qualification for any office or public trust under the Commonwealth.

${ }^{46}$ Attorney-General for Victoria; Ex rel Blackv The Commonwealth [the Defence of Government Schools case] (1981) 146 CLR 559 per Barwick CJ at 577 per Gibbs J at 594 and Wilson J at 652.

${ }^{47}$ Australian Constitution, supra note 45, section 116(2).
} 
Constitutional challenges to the High Court under section 116 have shaped the approach of the judiciary and parliaments to questions of state intervention in religion and religious freedom, ${ }^{48}$ although the Court did not grapple with the definition of religion question until Church of the New Faith in 1985, some 85 years after the commencement of the Australian Constitution. I discuss some key constitutional cases below, noting that the general approach has been for the High Court to interpret section 116 relatively narrowly, and to place limits on religious expression where it is seen to interfere with public order and other social interests. However, the High Court has also interpreted section 116 to enable the federal government to grant rights to certain religious groups (in early constitutional jurisprudence, the Christian churches within Australia) to act on behalf of the state in key areas of public regulation including healthcare and education.

The Commonwealth government relied on the High Court's relatively narrow approach to the establishment clause to argue for federal funding of religious schools (the Defence of Government Schools case) and the authorisation of some churches to carry out state functions. For example, the Marriage Power in the Australian Constitution has been used to support federal legislation establishing a Register of Ministers of Religion authorised to solemnise marriages and giving the sitting Governor General the power to declare 'recognised' religious denominations for this purpose. ${ }^{49}$ In consideration of the constitutional validity of this aspect of the Marriage Act, ${ }^{50}$ Justice French (as he then was) held that the recognition of certain types of religious marriages as valid under federal law does not constitute the 'establishment' of these religions and also did not constitute an interference with the free exercise of other religions. ${ }^{51}$

The High Court has also taken a conservative approach to the protection of free exercise of religious belief, particularly where those beliefs conflict with other public responsibilities. In the

\footnotetext{
${ }^{48}$ Section 76(i) of the Australian Constitution (supra note 45) provides that Parliament may confer original jurisdiction on the High Court in relation to matters that arise under the constitution or involving its interpretation. Constitutional matters are formally conferred as within the Court's original jurisdiction by operation of section 30 of the Judiciary Act 1903 (Cth).

${ }^{49}$ Patrick Keyzer, Principles of Australian Constitutional Law ( $3^{\text {rd }}$ Edition), (Sydney, Lexis Nexis Butterworths, $2010)$ at 275.

${ }^{50}$ Marriage Act, supra note 13 .

${ }^{51}$ Nelson v Fish (1990) 92 ALR 187, per French J at $191-192$.
} 
case of Adelaide Company of Jehovah's Witnesses Inc. v The Commonwealth, ${ }^{52}$ the Court considered pamphlets distributed by Jehovah's Witnesses that urged members to pacifism, and stated that members must 'have no part in the political affairs of the world and must not interfere with the drafting of men of nations that go to war, accordingly they refuse to take an oath of allegiance to the King'. ${ }^{53}$ The Court held that federal regulations declaring Jehovah's Witnesses to be a 'subversive organisation' did not fetter the guarantee of free exercise of religion in section 116, despite the fact that these regulations authorised the arrest and detention of Jehovah's Witnesses when they gathered in public space for religious meetings. Justice Starke, in holding that there was no breach of freedom of religion, stated that freedom of religion was necessarily "subject to limitations...such are necessary for the protection of the community and in the interests of the social order." 54

\section{Definition of 'religious belief' in Charters of Rights}

Section 14 of the Victorian Charter protects freedom of thought, conscience, religion and belief in terms similar to Article 18 of the ICCPR: ${ }^{55}$

14. Freedom of thought, conscience, religion and belief

(1) Every person has the right to freedom of thought, conscience, religion and belief, including-

(a) the freedom to have or to adopt a religion or belief of his or her choice; and

(b) the freedom to demonstrate his or her religion or belief in worship, observance, practice and teaching, either individually or as part of a community, in public or in private.

The expressions 'thought', 'conscience', 'religion' and 'belief' are not defined in the Victorian Charter, but reference can be made to Article 18 of the $\mathrm{ICCPR}^{56}$ to scope these terms, as section

\footnotetext{
${ }^{52}$ Adelaide Company of Jehovah's Witnesses Inc. v The Commonwealth (1943) 67 CLR 116 [Jehovah's Witnesses].

${ }^{53} \mathrm{Ibid}$, at $117-118$.

${ }^{54}$ Jehovah's Witnesses, supra note 52, per Starke J at 155.

55 International Covenant on Civil and Political Rights (1966) UN General Assembly, International Covenant on Civil and Political Rights, 16 December 1966, United Nations, Treaty Series, vol. 999, p. 171 [ICCPR].

${ }^{56} \mathrm{Ibid}$, article 18: 1. Everyone shall have the right to freedom of thought, conscience and religion. This right shall include freedom to have or to adopt a religion or belief of his choice, and freedom, either individually or in community with others and in public or private, to manifest his religion or belief in worship, observance, practice and teaching.

2. No one shall be subject to coercion which would impair his freedom to have or to adopt a religion or belief of his choice.

3. Freedom to manifest one's religion or beliefs may be subject only to such limitations as are prescribed by law and are necessary to protect public safety, order, health, or morals or the fundamental rights and freedoms of others. 4. The States Parties to the present Covenant undertake to have respect for the liberty of parents and, when applicable, legal guardians to ensure the religious and moral education of their children in conformity with their own
} 
32(2) of the Victorian Charter invites reference to international human rights instruments. The Court of Appeal was referred to these authorities and to the relevant text in Article 18, by the Victorian Commission in Cobaw. ${ }^{57}$

\section{Definition of 'religion' and 'religious freedom' in anti-discrimination law}

Religious freedom is also protected through the operation of anti-discrimination legislation, although the coverage is far less comprehensive than Canadian human rights legislation and section 2(a) of the Canadian Charter. All states and territories except NSW have legislation that explicitly prohibits discrimination on the basis of religion and religious expression. The term 'religion' is given little, if any, definition in these statutes, and is usually simply phrased as 'religious belief' or 'religious activity'. ${ }^{58}$ Notably, the South Australian EO Act only protects "religious appearance in dress in work or education" 59 and New South Wales has no protection against religious discrimination in its Anti-Discrimination Act. ${ }^{60}$ Rather, the definition of 'race' includes ethno-religious or national origin' and complainants must frame religious discrimination claims in a racial context. ${ }^{61}$

In a submission calling for an explicit federal law to protect religious freedom, the South Australian Equal Opportunity commented that the 'religious appearance' provision created unacceptable anomalies in legal protections against religious vilification and discrimination, particularly in the absence of federal legislative protection for religious freedom:

The new provisions...create another oddity in South Australian law. For example an employer will not be able to refuse to hire a man because he is wearing a yarmulke, but can still refuse to hire Jews. A person recently contacted the Commission because, during

convictions; Human Rights Committee, General Comment 22, Article 18 (Forty-eighth session, 1993). U.N. Doc. HRI $\backslash G E N \backslash 1 \backslash$ Rev.1 at 35 (1994) online: http://www1.umn.edu/humanrts/gencomm/hrcom22.htm [General Comment].

${ }^{57}$ Victorian Human Rights and Equal Opportunity Commission, Submissions for the Second Respondent in the matter of Christian Youth Camps ltd $v$ Cobaw Community Health Ltd and the Victorian Equal Opportunity and Human Rights Commission (SAPC I 2010 0143) (12 June 2012) 10 at 50 - 52 [Victorian Commission Submissions].

${ }^{58}$ For example: the schedule to the Anti-Discrimination Act 1991 (Q1d) provides that "religious activity" means engaging in or not engaging in or refusing to engage in a lawful religious activity, and "religious belief" means holding or not holding a religious belief.

${ }^{59}$ Equal Opportunity Act 1984 (SA) [South Australian EO Act]; S.A. Equal Opportunity Commission, Submission to the Australian Human Rights Commission's Submission to the Australian Human Rights Commission Inquiry Freedom of Religion and Belief in the 21st Century (27 February 2009), at 2.

${ }^{60}$ Anti-Discrimination Act 1977 (NSW).

${ }^{61}$ Ibid, section 4. 
an interview with a recruitment agent, he had been told, "I hope you're not a Jehovah's Witness". Comments such as these are not covered under the Act. ${ }^{62}$

Federal anti-discrimination Acts do not explicitly extend to protection of religious belief, although the federal Racial Discrimination Act $(\mathrm{Cth})(R D A c t)^{63}$ provides some limited protection against discrimination on the basis of religion. If a religious group can also be classified as an "ethnic" group, the RD Act may cover direct and indirect discrimination and vilification under the racial hatred provisions of the Act. ${ }^{64}$ Part III of the Australian Human Rights Commission Act 1986 (Cth) (AHRC Act) which governs the jurisdiction of the Australian Human Rights Commission) gives the Commission jurisdiction to hear human rights complaints in employment that relate to religious discrimination, ${ }^{65}$ however these complaints are not justiciable as the international covenants which define human rights are not enforceable under Australian law. 'Religion' under the AHRC Act is defined with reference to Article 18 of the International Covenant on Civil and Political Rights and 'religious discrimination' is defined with reference to Article 3 of the Declaration on the Elimination of All Forms of Intolerance and of Discrimination Based on Religion or Belief. ${ }^{66}$

In 2009, the federal industrial protection legislation, the Fair Work Act 2009 (Cth) extended protection against 'discrimination' in employment on the basis of 'religion', prohibiting an employer from taking 'adverse action' against an employee on religious grounds, including termination of employment. ${ }^{67}$ However, to date there are no recorded cases of employment discrimination on the basis of religious belief.

\footnotetext{
${ }^{62}$ SA EO Act, supra note 59; S.A. Equal Opportunity Commission, supra note 59 at 3.

${ }^{63}$ Racial Discrimination Act 1975 (Cth) [RD Act $]$.

${ }^{64}$ Australian Human Rights Commission, Information Paper: The Human Rights and Equal Opportunity Commission Act 1986 (Cth) it's application to religious freedom and the right to non-discrimination in employment, 8 March 2006, online: https://www.humanrights.gov.au/publications/hreoca-religious-freedom (last accessed 20 July 2014).

${ }^{65}$ AHRC Act, Part II Division 3 (supra note 34): A complaint may be made alleging that an act or practice is inconsistent or contrary to any human right: section 20(1)(b). 'Human Rights' are defined in section 3 of the Act to mean the rights and freedoms recognised in the international instruments which are declared or scheduled to the Act. ${ }^{66}$ ICCPR, supra note 56; Ibid, section 3: "Any distinction, exclusion, restriction or preference based on religion or belief and having as its purpose or as its effect nullification or impairment of the recognition, enjoyment or exercise of human rights and fundamental freedoms on an equal basis."

${ }^{67}$ Fair Work Act 2009 (Cth), section 351.
} 


\section{Religious exception provisions}

Each anti-discrimination statute in Australia, with the exception of the Racial Discrimination Act 1975 and the Disability Discrimination Act, have exception provisions to cover acts of religious bodies. ${ }^{68}$ The Disability Discrimination Act has no religious exceptions on the basis that there was no clearly identified religious doctrine, convention or belief system that would need to discriminate against people with a disability in order to comply with those religious beliefs. ${ }^{69}$ The religious exceptions in state and territory statutes vary in form and substance, however, as Carolyn Evans states:

[A]1l States and Territories provide exceptions for religions from the scope of ordinary discrimination law. Generally such exceptions are for 'any act or practice of a body established for religious purposes' that either 'conforms with the doctrines of the religion or is 'reasonably necessary to avoid injury to the religious sensitivities of adherents of the religion. ${ }^{70}$

Victoria has the broadest exceptions for religious conduct. The Equal Opportunity Act 2010 (Vic) (Equal Opportunity Act) includes specific exceptions for employment and service provision by religious schools, ${ }^{71}$ individuals who have particular religious sensitivities, ${ }^{72}$ and a section extending the definition of 'religious body' to include 'an entity that establishes, or directs, controls or administers, an educational or other charitable entity that is intended to be, and is, conducted in accordance with religious doctrines, beliefs or principles. ${ }^{73}$ Recent investigations into the operation of the religious exception provisions in the former Victorian Equal Opportunity

\footnotetext{
${ }^{68}$ The RD Act only has two exception provisions (sections 9(d) and (e) that deal with the enactment of special measures (affirmative actions), supra note 63.

${ }^{69}$ Australian Human Rights Commission, Submission to the Consolidation Project (Submission, 1 February 2012), at 34 [AHRC Submission].

${ }^{70}$ Carolyn Evans, Legal Protection of Religious Freedom in Australia (Sydney, the Federation Press, 2012) at 149.

${ }^{71}$ Equal Opportunity Act 2010 (Vic) [Equal Opportunity Act] Section 83(2): 'Nothing in Part 4 applies to anything done on the basis of a person's religious belief or activity, sex, sexual orientation, lawful sexual activity, marital status, parental status or gender identity by a person or body to which this section applies in the course of establishing, directing, controlling or administering the educational institution that-

(a) conforms with the doctrines, beliefs or principles of the religion; or

(b) is reasonably necessary to avoid injury to the religious sensitivities of adherents of the religion.'

${ }^{72} \mathrm{Ibid}$, Section 84: 'Nothing in Part 4 applies to discrimination by a person against another person on the basis of that person's religious belief or activity, sex, sexual orientation, lawful sexual activity, marital status, parental status or gender identity if the discrimination is reasonably necessary for the first person to comply with the doctrines, beliefs or principles of their religion.'

${ }^{73} \mathrm{Ibid}$, Section 81(1)(b).
} 
Act met with significant resistance from Christian lobby groups and church employers, ${ }^{74}$ and led to the Bracks' government committing publicly not to repeal or weaken the religious exceptions, regardless of the findings and recommendations of the Parliamentary Committee responsible for the review. ${ }^{75}$

\section{Religious freedom in Australia law: conclusions}

This overview demonstrates that there is no substantive definition of religious activity or religion for the purposes of Australian anti-discrimination law. The High Court's definition in Church of the New Faith is therefore relied on in cases where religious belief is asserted and there is a dispute as to the nature of the religious belief or the requirement of adherence to religious doctrine, even in different legislative contexts. ${ }^{76}$ There is very little consistency in legislative approaches to religious freedom and religious discrimination. This has led to a general view that religious freedom is important in Australian public life, but its status as a right, value or interest is not clear and there is very little hard guidance on when and how religious freedom should be limited in public life.

This lack of clarity is made more problematic by the fact that religious bodies provide a range of different services and roles in Australian public life that go beyond the normal bounds of 'religious services'. For example, the Anglican and Catholic churches have a longer history of providing educational establishments in Australia than the state, as they managed and funded educational institutions up to 150 years before Federation in 1901. Government schooling is largely seen as a recent addition to a Christian-based education system that has operated continuously since European settlement in Australia. ${ }^{77}$ Further, the privatisation of the delivery of government services in the late 1990s enabled churches and charity groups, for example Anglicare, Mission Australia, the Salvation Army, the Brotherhood of St Lawrence and Uniting Care to successfully tender to participate in the delivery of government programs in several

\footnotetext{
${ }^{74}$ Scrutiny of Acts and Regulations Committee, Victorian Parliament, Final Report concerning Exceptions and Exemptions in the Equal Opportunity Act 1995 (26 October 2009) 14 - 15.

${ }^{75}$ Melissa Fyfe, "Government bows to religious right", The Age, 27 September 2009, online: http://www.theage.cor.au/national/government-bows-to-religious-right-20090926-g76u.html (last accessed 2 August 2014).

${ }^{76}$ See: Cobaw, supra note 2, per Maxwell P at paras 223, $233-236$.

${ }^{77}$ Kaye, supra note 38 at $43-45$.
} 
fields, including relationship counselling, health, family planning and welfare services. ${ }^{78}$ The privatisation of the Commonwealth Employment Service in 2001 enabled church agencies such as Mission Australia (run by the Wesley Mission Church) and the Salvation Army's 'Employment Plus' program to replace state run agencies as the largest employment services for long-term unemployed people in Australia.

\section{Equality rights under Australian law}

There is no fundamental recognition of equality as a defining social value in Australia that mirrors section 15 of the Canadian Charter or section 26 of the ICCPR. ${ }^{79}$ The Australian Constitution gives no recognition to equality or anti-discrimination rights, and until 1975 (with the introduction of the RD Act), there was no legislative recognition of equality guarantees at a federal, state or territory level. However, over the last 30 years, there has been increased recognition of equality as a significant value and right in Australian public life. This recognition takes the form of complex and comprehensive anti-discrimination coverage (summarised above), and in the form of equality guarantees in the Victorian and A.C.T. Charters.

In the first case to consider the relationship between the Equal Opportunity Act and the Victorian Charter, ${ }^{80}$ Justice Bell explicitly linked the Victorian Charter definition of equality rights with the objects of state anti-discrimination laws and found that both legal guarantees constituted domestic recognition of Australia's obligations to recognise equality rights under Article 26 of the ICCPR. ${ }^{81}$ Justice Bell considered that the legal guarantees of equality rights within these statutes reflected the natural position of equality rights as the prime and fundamental democratic rights:

Equality and non-discrimination are the foundation of the rule of law and democratic society in which everybody knows they are recognised in law as human beings of equal

\footnotetext{
${ }^{78}$ John Warhurst, "Religion and politics in the Howard decade" 200742 Australian Journal of Political Science, 19 32 , at 26 .

${ }^{79}$ ICCPR, supra note, 57, article 26: "All persons are equal before the law and are entitled without any discrimination to the equal protection of the law. In this respect, the law shall prohibit any discrimination and guarantee to all persons equal and effective protection against discrimination on any ground such as race, colour, sex, language, religion, political or other opinion, national or social origin, property, birth or other status."

${ }^{80}$ Lifestyle Communities Ltd (No 3) (Anti-Discrimination) [2009] VCAT 1869 (22 September 2009) [Lifestyle Communities].

${ }^{81} \mathrm{Ibid}$, at $115-118$.
} 
worth and potential, and equally deserving of concern, respect and consideration. The equality rights in $\mathrm{s} 8$ are the keystone in the protective arch of the Charter. ${ }^{82}$

Victoria is a unique jurisdiction in Australia as it includes a human rights guarantee of equality that references international legal principles about the scope of equality rights and links those guarantees to anti-discrimination law. ${ }^{83}$ However, Justice Bell's assertion that equality laws reflect equality rights as a universal 'social value' is less persuasive when applied to the majority of Australian jurisdictions that operate without a human rights framework. Unlike Canada, Australian anti-discrimination legislation is not 'quasi-constitutional' and there are no special rules of interpretation that apply to human rights principles. ${ }^{84}$ Rather, the High Court has provided the comparatively bland mandate that anti-discrimination Acts are 'beneficial legislation' that are designed to be rights protective. As such, courts and tribunals have a responsibility to 'give effect to the purposes and objects of the legislation and to construe those provisions broadly. ${ }^{85}$ Some anti-discrimination Acts reference international principles in their objects and purposes clause, such as the Australian Human Rights Commission Act, ${ }^{86}$ but most do not, and it is therefore very difficult for courts to 'read in' international principles about the scope of equality rights without this legislative direction.

\section{Conflict of rights: discrimination law as a balancing framework}

Tension between free exercise of religion and equality rights in Australia is most clearly demonstrated in discrimination complaints, as anti-discrimination legislation operates, in the absence of a constitutional bill of rights or human rights Act, as a de facto human rights framework. Because of the piecemeal approach to human rights protection under law that I have described above, anti-discrimination Acts have taken on increased significance for determining limitations of rights and reconciling conflicts between equality rights and other human rights.

\footnotetext{
82 Ibid, at 277.

${ }^{83}$ Victorian Charter, supra note 4, section 8(1), 8(4), section 32(2).

${ }^{84}$ Momcilovic, supra note 24, per Gummow J and Haydon JJ.

${ }^{85}$ Waters v Public Transport Corporation (1991) 173 CLR 349 at 359 per Mason CJ and Gaudron J; IWv City of Perth (1997) 191 CLR 1 at 14 per Brennan CJ and McHugh J at 22-23, per Gaudron J, at 27 per Toohey J, at 39 and 41- 42 per Gummow J and 58 per Kirby J; Xv Commonwealth (1999) 200 CLR 177 at 223 Kirby J; and Qantas Airways Limited $v$ Christie (1998) 193 CLR 280 at 332 per Kirby J.

${ }^{86}$ AHRC Act, supra note 34, section 3.
} 
Some of the most contentious aspects of the rights debate involves the rights of freedom of religion and equality rights.

It is difficult to strike a balance between rights in this legislative context because antidiscrimination statutes have as their primary goal the protection of equality rights and ensuring freedom from discrimination in areas of public life and are not designed to provide a limitations analysis for a competition between conflicting rights. To date, there has been limited academic attention paid to the operation of the 'religious expression' protective clauses in state and federal anti-discrimination law or the consequence of these clauses in relation to competing conceptions of human rights. Analysis of religious discrimination in Australian laws and protection against religious discrimination have tended to be of greater academic interest than the impact of religious exception provisions on discrimination law. ${ }^{87}$ This is partly a result of the limited protection offered by federal anti-discrimination statutes to religious identity and religious expression, and partly a result of the broader human rights debate about whether Australia should adopt a charter of rights.

\section{'Protect religious freedom': a task for equality frameworks?}

The view taken by most religious bodies in Australia is that religious exceptions in equality law demonstrate Parliament's intention to offer substantial protection to religious freedom as a right under Australian law. Attempts to strengthen or unify existing anti-discrimination law or to introduce further human rights protections are opposed on the basis that these changes would increase novel, liberal concepts of equality rights such as group rights and special measures at the expense of personal freedoms and autonomy.

An report into religious freedom carried out by the Australian Human Rights Commission (Commission) in 2011 found that the majority of Christian groups in Australia favour less, rather than more, legislative protection of the freedom of religion, less 'state interference' in terms of

\footnotetext{
${ }^{87}$ See: Evans, supra note 72; Ernst Willheim “Australian legal procedures and the protection of secret Aboriginal spiritual beliefs: a fundamental conflict", in Peter Cane, Carolyn Evans and Zoe Robinson eds, Law and Religion in Theoretical and Historical Context, (Sydney, University of New South Wales Press, 2008) pp. 214 - 242; cf: John Tobin "Should discrimination in Victoria's public schools be protected: using the Victorian Charter of Human Rights and Responsibilities to achieve the right balance" (2010) 16 MonashULawRw 36(2) online: http://www.austlii.edu.au/au/journals/MonashULawRw/2010/16.html (last accessed 25 March 2014).
} 
dialogue between religious groups and the preservation of 'special exemptions' for religious groups as the means of protecting religious interests against the "discrimination law left wing agenda." 88 The Presbyterian Church commented in their formal submission:

[T] he ability to discriminate on the basis of an organisation's core commitments and values is central to the democratic freedoms of our country. The tendency in some (political) quarters to portray religious bodies as somehow different from other social institutions is unfortunate. ${ }^{89}$

Some Christian faiths reported to the Commission that they view Australia as a Christian nation, with Christian values forming the bedrock of our legal system, public institutions and social and political structures and that the Australian government must respect the Christian religion as its first responsibility. ${ }^{90}$ The Commission report chronicled widespread anxiety among Christian groups about religious plurality and its relationship to discrimination laws. A member of the New South Wales Christian Lobby commented:

I'm concerned with the dumbing down of law to accommodate diversity - soon it'll be a great big melting pot of world views to a coffee coloured mix that does nothing to inspire and then you'll have victims everywhere. Can we accommodate Shari'a law or tribal Hindu law? We don't want to end up with two lots of conflicting law in Australia. ${ }^{91}$

The anxieties expressed by Christian groups in relation to the protection of 'religious freedom' in Australian law demonstrate a related concern about pluralism in Australian legal attitudes to religion and the belief that 'pluralism' equates to secularism. The Commission found that minority religions (where public membership of religious groups was much lower than Christian churches) tend to strongly support interfaith initiatives and are supportive of views of Australia as a multifaith country. However, conversations about multifaith initiatives tended to focus on the rights of different religious groups and individuals to profess their faith in different ways. The

\footnotetext{
${ }^{88}$ Bouma, Gary Desomd Cahill, Hass Dellal et al for the Australian Human Rights Commission, Freedom of religion and belief in 21st Century Australia (Final Report) (2011) at 16.

${ }^{89} \mathrm{Ibid}$ at 37.

${ }^{90}$ Ibid at 23.

${ }^{91}$ Ibid 24; footnote 39 .
} 
Commission therefore concluded that "conversations tended to focus on religious diversity and interrelations rather than on multifaith as a component of plurality in civil society." 92

Christian organisations indicated a reluctance to recognise Australia as 'multifaith' and resisted interfaith activities, particularly those activities that involved interaction with humanist societies. The Victoria Australian Christian Lobby commented that there was no value in interfaith activities because these activities are 'too liberal' and involvement requires a Christian to concede elements of their faith: "there can be no compromise to one's religious beliefs - we don't all just view religion differently...that attitude is ok for liberalists, but not for ordinary Christians." ${ }^{93}$ This critique of multifaith and multicultural engagement between people of faith reflects the strong view of Australian Christian churches that the Christian faith is the Australian religion and that the recognition of religious diversity is a hallmark of liberalism and cultural relativism, two aspects of political liberalism that Christian churches find supremely difficult to resolve with their faith.

On the other side of the debate: there has been unified opposition from the Australian human rights sector (including human rights commission, expert academic centres on discrimination, New South Wales and Victoria Legal Aid Commissions and NGO groups) about the continued inclusion of religious exceptions in federal anti-discrimination law. During the federal discrimination law Consolidation Project consultation in 2012, the Australian Council of Human Rights Agencies (ACHRA) voiced strong opposition to the continued recognition of religious freedom in these exception provisions:

While ACHRA acknowledges that actions taken to conform with religious doctrines are important and respect the right to freedom of religion, these considerations must be balanced against competing rights in the context of the authorising legislation. ACHRA considers that, without amendment, the religious exemptions currently included...constitute an unreasonable limitation on competing human rights (notably the equality right protected by anti-discrimination legislation, but also rights of privacy, freedom of expression and association).$^{94}$

\footnotetext{
92 Ibid at 28.

${ }^{93}$ Bouma, Cahill, Dellal and Zwartz, supra note 88 at 29.

${ }^{94}$ Australian Council of Human Rights Agencies (ACHRA), Submission to the Consolidation Project (Report, 1 February 2012), at $49-50$.
} 
ACHRA recommended that a consolidated federal human rights Act should distinguish between those religious activities that are 'core' to a religious belief system and celebration of faith (for example, rules about the ordination of priests or ministers and clothing that must be worn at religious ceremonies) and activities that are 'non-core' or external to such a belief system, including decisions about hiring people in non-faith based roles in a religious school or offering goods and services on a non-discriminatory basis in all commercial endeavours, including statefunded recreational services, social work or health care. ${ }^{95}$

The position of ACHRA is that the purpose of equality statutes is to prohibit, as far as possible, discrimination in areas of public life. The role of religious 'exceptions' or 'exemptions' is, on this view, to provide a limitation on this prohibition and create a permanent exemption to its operation rather than provide for a complementary or alternative right to be protected. Human Rights Commissions therefore argue that the exceptions must be interpreted narrowly, in contrast to the broad and beneficial reading that courts generally agree should be accorded to antidiscrimination statutes.

\section{An Australian judicial approach to rights reconciliation: Cobaw}

This section considers the recent decision of the Victorian Court of Appeal (the Court) in the Cobaw decision. This decision provides the most recent of the conflict of rights issue between freedom of religion and equality rights. The decision was handed down on 14 April 2014, 14 months after oral submissions. As prefaced in the Introduction, Cobaw is one of the first cases in which a superior Court explicitly recognised the centrality of the issue of rights conflict and the interplay between different conceptions of human rights protection under anti-discrimination law. ${ }^{96}$ His Honour President Maxwell stated in the introduction to his judgment:

Central to the resolution of the questions raised by the appeal is the correct interpretation of the provisions of the EO Act. What has to be discerned is how the Victorian Parliament intended that the 'balance' be struck between the right to freedom from

\footnotetext{
95 Ibid.

${ }^{96}$ While similar issues related to the application of religious exception provisions to state funded adoption centres were considered by the New South Wales Court of Appeal in the case of $O V \& O W v$ Members of The Board of The Wesley Mission Council [2010] NSWCA 155. However, the Court in that case did not approach these issues from a human rights perspective nor did it engage in a 'rights balancing' exercise in its determination of the legal question (the application of the exception provision in the NSW Act).
} 
discrimination and the right to religious freedom, where the two came into conflict. ${ }^{97}$

The Court directed its approach to rights reconciliation through the lens of two religious exception provisions set out in the Equal Opportunity Act 1995 (Vic) (Equal Opportunity Act). ${ }^{98}$ At issue was how the Court should construe the exception provisions that enable a religious body and persons with religious sensitivities to discriminate on the basis of sexual orientation.

A case analysis of the decision by the Australian Human Rights Law Centre (HRLC) argues that it is of limited impact, as the Court merely upheld the central findings of the Tribunal, and that decision was "based on factual findings on the evidence before it, not on an abstract consideration of the scope of the right to equality, the right to religious freedom, or how the two intersect." $" 99$ The HRLC notes that the religious exception provisions are altered in the amended Equal Opportunity Act 2010 (Vic). This critique raises valid points about the limited relevance of the decision to later claims of discrimination brought under the 2010 Equal Opportunity Act. However, there are strong points of similarity between the religious exception provisions in both Acts. Further, each state and territory jurisdiction contains similar provisions to the Equal Opportunity Act. It is therefore simplistic to assert that there are no circumstances in which a Court would be guided by the Cobaw decision in relation to claims of religious exceptions under alternate state anti-discrimination laws.

Further, this critique does not address those aspects of the Court's decision that grapple with the broader 'conflict of rights' issue. The Court deals this question as it arises in the factual context of the complaint and applies a statutory interpretation approach to the question of rights balancing, discarding other suggested approaches that include the application of the limitations provision in the Victorian Charter to determine the internal limits of the rights, the application of international human rights principles or a broad reading of exception provisions on the basis of

\footnotetext{
${ }^{97}$ Cobaw, supra note 2 per Maxwell $\mathrm{P}$ at para 9 (emphasis added).

${ }^{98}$ Equal Opportunity Act 1995 (Vic) [Equal Opportunity Act]. The Act has now been replaced with the Equal Opportunity Act 2010, supra note 71. However, the religious exception provisions at issue in Cobaw are substantially re-enacted in sections 84, 85 and 87 of the 2010 Equal Opportunity Act, see: supra note 71.

${ }^{99}$ Emrys Nekvapil and Anna Brown for the Human Rights Law Centre "Case Note: Christian Youth Camp's refusal of booking request to same-sex attracted youths was unlawful discrimination", 16 April 2014, online:

http://hrlc.org.au/christian-youth-camps-refusal-of-booking-request-to-same-sex-attracted-youths-was-unlawfuldiscrimination (last accessed: 17 July 2014).
} 
complementary rights protection. This is significant in terms of crystallising an Australian 'approach' to rights conflict as it arises in human rights legislation. Each of the three judgments contain a careful discussion of the scope and application of religious exception provisions and apply case law in relation to the relevance of international conventions in a consideration of Australian legal provisions, the issue of whether a religious entity can discriminate in its commercial activities and the broader question of when and how a religious corporation is protected by religious exceptions. The significance of the Court's reasoning on this point should not be limited to the facts in the dispute.

There are two issues in the Cobaw case that are relevant to this work. The first is the approach to 'rights reconciliation/conflict' that the Court took, and the explicit recognition of the limited relevance of international law and human rights frameworks to its analysis. The second is the Court's treatment of the 'religious body' issue: in terms of how it applied the exception provisions to the actions of a commercial entity claiming a religious exception.

I will also make some targeted criticisms about the Court of Appeal's approach to the rights conflict in this case, in comparison to the relative clarity of debate in Canada around similar issues of rights conflict between equality and freedom of religion. While the Australian 'statutory interpretation' approach might be the best available in the absence of a guiding rights document, it creates an overly complex and technical matrix for determining reasonable limitations of religious freedom in modern society and does not give sufficient guidance to future claimants about the obligations of religious bodies in areas of public life subject to anti-discrimination law. Recourse to a limitations test similar to section 7(2) of the Victorian Charter would have crystallised the rights issues before the Court and enabled it to explicitly map a balancing exercise for rights that would (a) have provided stronger rights claims to justify the outcome reached and (b) provided a 'values compass' for later courts considering similar issues and facts. My analysis of the approaches preferred by Canadian courts applying either the section 1 Canadian Charter test or the 'reconciliation of rights' approach corresponds directly to these points. I discuss these tests in detail in Chapter 3. 


\section{Facts and background}

The facts of Cobaw arise out of a representative discrimination complaint by Cobaw Community Health Services Ltd (Cobaw) against Christian Youth Camps (CYC). Cobaw runs a suicide prevention program (the WayOut Project) focusing on 'same sex attracted young people'. ${ }^{100}$ The aims of the WayOut project are 'to raise awareness about their needs and the effects of homophobia and discrimination on young people and rural communities generally' ${ }^{101} \mathrm{CYC}$ was established by the trustees of the Christian Brethren Trust, a legal entity established for purposes connected with the Exclusive Brethren Church of Australia. The alleged discriminatory conduct occurred when Mr. Rowe, the onsite manager of CYC and a member of the Exclusive Brethren Church, refused to accept a booking from Cobaw for a campsite on the basis of its homophobiaprevention manifesto. Ms. Hackney, an employee of Cobaw, told Mr. Rowe about the WayOut project and goals, including the belief that homosexuality was a normal part of the range of human sexualities and that the camp at CYC would involve workshops to plan awareness-raising efforts for WayOut. ${ }^{102}$

Mr. Rowe told Ms. Hackney that CYC would not accept this booking on the basis of Christian belief. Both CYC and Mr. Rowe maintain their opposition to homosexual activity and the promotion of homosexuality on the basis of religious doctrine set out in the Bible. Specifically, CYC pointed to the doctrine of plenary inspiration, which requires religious adherents of the EBC to interpret the Bible literally and to find the spirit of God in its passages.

The Tribunal held that the refusal of the booking amounted to unlawful discrimination on the basis of the sexual orientation of the young people who would be attending the camp. This finding was upheld by all members of the Court of Appeal, although each member of the Court reached different findings as to who was the primary discriminator and whether the vicarious liability provisions operated to attach secondary liability to CYC.

\footnotetext{
${ }^{100}$ Cobaw, supra note 2 per Maxwell $\mathrm{P}$ at para 3.

${ }^{101} \mathrm{Ibid}$, per Maxwell $\mathrm{P}$ at para 4.

102 Nekvapil and Brown, supra note 99.
} 
CYC submitted that two of the religious exception provisions in the Equal Opportunity Act applied to Mr. Rowe's conduct and that of CYC. These exceptions apply to conduct "by a body established for religious purposes" 103 where that conduct is necessary to uphold genuine religious beliefs and to discrimination by a person which is necessary for that person to comply with their "genuine religious beliefs or principles." 104 The Tribunal held that neither exception was applicable in the circumstances. ${ }^{105}$ Central to the Tribunal's decision were two findings: (a) that CYC was not a body constituted for religious purposes and (b) that it was not 'necessary' for either Mr. Rowe or Cobaw to discriminate against homosexual people in the way they did in order to comply with their religious sensitivities.

\section{Issue 1: no protection for a corporate entity: no religious purpose}

The Court's one point of agreement was on the question of CYC's religious purposes: all members of the Court accepted that CYC was not a body constituted for religious purposes, on the basis that CYC's conduct of a commercial camp business "is not, in any relevant sense, a 'religious' activity." ${ }^{106}$ Maxwell P concluded and the rest of the Court agreed, that at best, CYC was a commercial activity intended to raise money to enable its trustees to advance purposes consistent with the doctrines of the EBCA (although noting that many of these purposes were charitable rather than strictly religious). ${ }^{107}$

The Court reasoned that the Tribunal was correct to take into account the fact that CYC allowed many secular groups to attend its campsite (including football clubs and university associations) and did not make inquiries of its clients about their religious beliefs or sexual orientation. The Court therefore rejected the view that a corporate entity owned and controlled by a religious body (but with no purposive link to religious activity itself) can necessarily act in a religious manner, such as to exclude it from obligations under anti-discrimination law. However, the Court left

${ }^{103}$ Equal Opportunity Act, section 75(2), supra note 98.

${ }^{104} \mathrm{Ibid}$, section 77.

${ }^{105}$ Cobaw VCAT, supra note 1 at para 324.

${ }^{106}$ Cobaw, supra note 2 per Maxwell $\mathrm{P}$ at para 266.

${ }^{107} \mathrm{Ibid}$, per Maxwell P at paras $240-243$. 
open the question of whether such a body would constitute a 'religious body' for the purposes of the amended definition in the 2010 Equal Opportunity Act.

\section{Issue 2: The Court's approach to the question of rights conflict}

Each member of the Court agreed that the task for the Court was not to necessarily apply 'human rights principles' to the task of statutory interpretation, but was rather to construe the language of the exception provisions "in its statutory context" (a broad protection of equality rights), while having regard to the stated purpose of those provisions to protect the right of religious freedom. ${ }^{108}$ While to an observer, such a task necessarily involves resolving a question of rights conflict, the Court did not address this issue directly or describe the competing interests of the parties in this way. In his leading judgement, Maxwell $\mathrm{P}$ summarised the proposed approaches to rights reconciliation put by the Victorian Equal Opportunity and Human Rights Commission (Victorian Commission) and the Attorney-General for the State of Victoria (Attorney-General):

1. Whether the Victorian Charter applied to the dispute (the Victorian Commission argued that it did and that the application of section 7(2) could resolve the rights conflict issue). ${ }^{109}$

2. Whether the "special character of the religious freedom exemptions, being themselves protective of a human rights, required the adoption of a broad approach to their interpretation. (The Attorney-General preferred this approach, arguing that equality rights must be therefore be on an equal footing with freedom of religion rights in a rights balancing exercise).

3. Whether and to what extent the interpretation of the exemptions might be informed by jurisprudence relating to the religious freedom guarantees in international human rights instruments. ${ }^{110}$ (Both intervenors and Cobaw proposed that international human rights principles should be applied to the rights engaged to properly determine their scope).

Maxwell $\mathrm{P}$ addressed these three proposed means of rights resolution and rejected them all in favour of common rules of statutory interpretation, although acknowledging that international

\footnotetext{
108 Ibid, per Maxwell $\mathrm{P}$ at para 197.

${ }^{109}$ Victorian Commission, submissions, supra note 57 at paras $62-63$.

${ }^{110}$ Cobaw, supra note 2 per Maxwell P at para 167.
} 
human rights principles could provide some assistance in 'scoping the rights engaged'. However, the role of international human rights principles was then diminished by the Court's insistence that the exception provisions themselves 'reflect the careful balance struck by Parliament with respect to competing rights'. ${ }^{111}$ The Court insisted, somewhat artificially, that there was a plain meaning of sections 75 and 77 available and therefore human rights principles were of limited use to the statutory interpretation assessment.

The Court did not apply the Victorian Charter on a threshold determination that the operative provisions in the Charter were not in force until after the discriminatory action had already occurred. ${ }^{112}$ Maxwell P and Neave JA agreed, however, that the balance of rights struck by the Tribunal in the initial decision was correct, despite the fact that Judge Hamper applied Charter principles and section 7(2) in finding that sections 75 and 77 of the Equal Opportunity Act could be interpreted consistently with both the right to equality and the right to religious freedom. This is a puzzling concession in a decision where all members of the Court resisted attempts to frame their analysis of rights in a human rights based approach and suggests that the majority saw the 'balance struck' in the exception provisions as substantially reflecting the balancing test in section 7(2) of the Charter.

While the human rights principles that the interveners took the Court to are too numerous to include in total here, some key principles must be set out, as these principles correspond (in general terms) to the rights limitation principles adopted by the Supreme Court of Canada in Dagenais and in other Canadian cases where freedom of religion has been considered. ${ }^{113}$ The Victorian Commission argued that discrimination law may often involve a conflict between different civil and political rights, however, applying international human rights jurisprudence and comments by the United Nations Human Rights Commission, the following principles must apply to the interpretation of religious exceptions:

\footnotetext{
111 Ibid, per Maxwell $\mathrm{P}$ at para 197.

112 Ibid, per Maxwell P at paras $168-179$.

${ }^{113}$ See: Chamberlain v. Surrey School District No. 36, 2002 SCC 86, [2002] 4 S.C.R. 710; Marriage Commissioners Appointed Under The Marriage Act (Re), 2011 SKCA 3.
} 
1. none of the human rights in issue are absolute and all may be limited; ${ }^{114}$ and

2. if there are apparently conflicting human rights at play, the role of a decision-maker is to strike a balance that recognises that all relevant rights may be reasonably limited; ${ }^{115}$ and

3. Specifically, the right to manifest (express) a religious belief is a narrower right than the right to freely hold a religious belief, ${ }^{116}$ and this is particularly the case when the religious expression occurs in an area of life not connected to religion. ${ }^{117}$

The majority held that the Tribunal was right to assert that the protection of equality rights in the EO Act was a broad right and that the exception provisions must be read in light of the breadth of that protection. However, it did not accept the Commission's submission that exception provisions in anti-discrimination legislation must be given a careful and confined reading, particularly in light of international guidance on point. ${ }^{118}$ All justices eschewed a human rights approach to either scoping the rights in question or providing a justification for their findings as to whether or not there was a conflict of rights on the facts and whether this conflict could be satisfactorily resolved.

Rather, the majority engaged in a technical analysis of the exception provisions, and focused its findings on the non-religious nature of CYC and the question of whether it was 'necessary' for Mr. Rowe to respond to Cuba's request in the way that he did, applying the religious doctrines of his belief. It was not disputed by any of the parties that Mr. Rowe genuinely and sincerely held a religious belief that homosexuality was sinful. However, the majority held that the Tribunal was right to interpret the term 'necessary to comply with' religious principles in section $75(2)$ as requiring there to be 'no alternative to engaging in the conduct' in order to protect religious sensitivities ${ }^{119}$ and that the Tribunal was able to hold, as it did, that there was no 'requirement' in a plain reading sense that $\mathrm{Mr}$. Rowe discriminate against homosexual people in renting out camp

\footnotetext{
114 Victorian Commission, submissions, supra note 57 at paras 4, 12 .

115 Ibid, at para 39.

${ }^{116}$ C v United Kingdom App. No. 10358/83, 37 ECHR Dec \& Rep 142 at 147; McFarlane v Relate Avon Ltd [2010] EWCA Civ B1 at $22-25$.

${ }_{117}$ Pichon Sajous v France App. No. $49853 / 99$ (9 October 2001); Ahmad v United Kingdom (1981) 4 EHRR 126 at 11.

118 Victorian Commission, submissions, supra note. 57 at paras $14-16$; $\underline{\text { see also: }}$ Xv Commonwealth supra note 85 Per Kirby J at 223 and Qantas Airways Limited $v$ Christie supra note 85 at 333.

119 Cobaw, supra note. 2, per Maxwell at para 291.
} 
premises. Maxwell P and Neave JA both relied on their finding that CYC was not a religious body or 'place of religious observance' to reach this conclusion. ${ }^{120}$

Both Maxwell J and Neave JA held that 'a' right to religious freedom was engaged by the actions of CYC and Mr. Rowe. Maxwell P accepted the submission that courts should, as a matter of principle, favour a construction of legislation that accords to Australia's international obligations. ${ }^{121}$ However, he then resisted applying consequent principles in international human rights law that would guide the Court's balancing of competing human rights in the exception provisions, noting that "all that could be said is that the provisions of the EO Act are in conformity with, not in conflict, with those [international human rights] obligations. ${ }^{122}$ His Honour President then analyses the internal meaning of both exception provisions with close reference to the Tribunal's initial findings as to whether it was 'necessary' for CYC to discriminate against Cuba's members. His Honour President held that the findings of the Tribunal were reasonably available on the evidence and should not be disturbed. ${ }^{123}$

In relation to the more difficult questions of religious doctrine and connection between religious views and the discriminatory conduct, his Honour held that he did not have to decide these questions (in relation to section 75(2)) as CYC was not entitled to rely on the exception. However, he went on and made findings in the alternative on these grounds, holding that it was open to the Tribunal to find that it was not necessary for CYC to discriminate against gay people in order to confirm with their beliefs. ${ }^{124}$

Neave JA, because of her finding that Mr. Rowe was personally liable for the discrimination in addition to CYC, went on to find that it was not necessary for him to discriminate against gay people in the way that he did, in order to conform to his religious beliefs. In so finding, Neave JA preferred an objective approach to the question of what was 'necessary' for a religious belief. ${ }^{125}$ In evaluating what was required for a person to meet their religious obligations, her Honour

${ }^{120}$ Ibid, per Maxwell P at paras $305-307$.

${ }^{121}$ Ibid, per Maxwell P at para 192.

122 Ibid, per Maxwell P at para 194.

${ }^{123} \mathrm{Ibid}$, per Maxwell P at paras $260-262$.

${ }^{124} \mathrm{Ibid}$, per Maxwell P at paras $287-288$.

${ }^{125} \mathrm{Ibid}$, per Maxwell P at para 426. 
accepted the Commission's submission that there was a difference between the breadth afforded to holding a belief versus manifestation of that belief:

When read together with the exceptions ss 75 and 76, an objective approach enables a balance to be struck between protecting the right of individuals to hold religious beliefs and express them in worship and other related activities and protecting the rights of other members of a pluralism society to be free from discrimination. ${ }^{126}$

Neave JA held that it was relevant, under the objective approach, that Mr. Rowe voluntarily undertook responsibilities that he knew could have affected his ability to manifest his religious belief (his employment), and that this voluntary assumption of 'risk' to religious freedom must be taken into account when determining the balance between religious freedom and freedom from discrimination. ${ }^{127}$ This argument about the voluntary nature of Mr. Rowe's engagement with Cobaw and the commercial context, led her Honour to conclude that the discriminatory conduct was not 'necessary' for him to comply with his Christian beliefs.

In addition, Neave JA took into account the nature of Mr. Rowe's religious beliefs and concluded that they did not, of themselves, require him to discriminate against gay people in the way that he did. In so finding, her Honour held that it was necessary for Mr. Rowe "to abstain from homosexual relationships in order to comply with his belief that homosexuality is a sin. However, peripheral behaviour in relation to this belief... was not necessary to comply with that belief." 128 Her Honour had reference to international human rights cases supporting her findings on the breadth of religious freedom, although she did not clearly indicate what persuasive status she gave these decisions in light of her acceptance of the standard statutory interpretation model of rights balancing.

Redlich J, by comparison, considered that the Tribunal had not struck the right balance when it considered the exception provisions, because section 77 applied to CYC's discriminatory action and authorised it. Redlich J was adamant that the task of the Court was merely to apply the exception provisions as written, and reasoned that Parliament had already struck the balance

${ }^{126}$ Ibid, Neave JA, at para 430.

127 Ibid, Neave JA, at para 140.

${ }^{128}$ Ibid, Neave JA, at paras 142, at 436. 
between equality and freedom of religion rights when the Minister introducing the amending Act stated that the exception aimed to "strike a balance between two very important and sometimes conflicting rights- the right to freedom of religion and the right to be free from discrimination." 129 His Honour then applied the general rule that a statute is only to be applied consistently with international law where the terms of the text are not clear:

Where the terms of the text are clear...international human rights norms, and comparative judicial decisions interpreting and applying them... have no role in interpreting the provision or in its application to the facts. ${ }^{130}$

His Honour concluded, applying principles of statutory interpretation, that the only 'limitation' on religious freedom is that it relate to a discriminatory act. Redlich $\mathrm{J}$ thus divested himself of the obligation to review any international human rights principles or any from comparative jurisdictions. However, in holding that the Tribunal erred in its conclusion that the right to religious freedom was limited by the commercial nature of CYC's conduct, his Honour applies a broad view of religious freedom, without relying on any precedent or a close reading of the statutory text:

Religious faith is a fundamental rights because our society tolerates pluralism and diversity and because of the value of religion to a person whose faith is a central tenet of their identity. The person must, within the limits prescribed by the exemptions, be free to give effect to that faith. ${ }^{131}$

Redlich $\mathrm{J}$ considers that this broad reading of religious freedom justifies a balancing of rights to prefer religious freedom to equality values, even where the conflict occurs in the commercial sphere. His Honour cites Brockie v Brillinger ${ }^{132}$ as relevant to the facts in Cobaw and as supporting the proposition of a broad reading of the religious freedom in commercial contexts. This reliance on Brockie is curious, as the Ontario Divisional Court held that Mr. Brockie's exercise of his freedom of religion right in the commercial marketplace "is, at best, at the fringes of that right" and limits on his freedom of religion right are justified where the exercise of that

\footnotetext{
${ }^{129}$ Ibid, per Redlich J at para 548; Victoria, Parliamentary Debates, Legislative Assembly, 4 May 1995 (Jan Wade, Attorney-General) at 1254.

${ }^{130} \mathrm{Ibid}$, per Redlich J at para 554.

${ }^{131}$ Ibid, per Redlich J at para 561.

${ }^{132}$ Brockie v Brillinger (No. 2) (2002) 43 C.H.R.R. D/90 (Ont. Sup. Ct) [Brockie].
} 
right causes harm to others." 133 However, Redlich J relies on the Court's second holding that equality values should not be so broadly construed to require Mr. Brockie to provide "services which could strike at the core elements of his religious beliefs and conscience."134

While the application of the facts of Brockie to the facts in Cobaw is apposite, the judgment can just as simply be applied in support of the majority's reasoning: namely that the commercial purpose of CYC put its actions at the 'periphery' of the right of religious freedom rather than towards the protected core. Further, his Honour's comments about Brockie reference the Canadian Charter $^{135}$ and relevant religious freedom jurisprudence, ${ }^{136}$ but do not discuss the rights framework (and limitation principles) that operates in Canada and that guide judicial consideration of rights in decisions such as Brockie.

His Honour concluded that the Court, in Brockie, had 'struck the right balance' between rights in the absence of a legislative provision that sought to do so (such as an exemption provision) and should be persuasive on this basis. ${ }^{137}$ However, in Brockie, the Court considered the defence of bona fide and reasonable justification on the basis of religious belief in employment (set out in section 35 of the Ontario Human Rights Code), ${ }^{138}$ but considered the defence did not apply to Mr. Brockie's conduct. ${ }^{139}$ Further, the Court also found that the limits on Mr. Brockie's religious freedom were warranted under section 1 of the Charter. ${ }^{140}$ The case of Brockie is an excellent example of the Canadian rights framework in action in a discrimination claim, and the way that framework seeks to resolve a conflict of rights. Had his Honour sought to apply the rights balancing principles set out in Brockie to his reasoning (rather than its factual matrix), he might have arrived at a different result in terms of valid religious expression in the public square, certainly in the context of CYC's actions. However, his rejection of international approaches to the question of rights conflict precluded him from applying the Canadian principles or tests to either of the religious exception provisions.

\footnotetext{
${ }^{133}$ Ibid, at $54-55$.

${ }^{134} \mathrm{Ibid}$, at 56 - 57, Cobaw, supra note 2 per Redlich J at paras $543-545$.

${ }^{135}$ Charter, supra note 7.

${ }^{136}$ R. v. Big M Drug Mart [1985] 1 S.C.R. 295, (1985) 18 D.L.R. (4 $\left.{ }^{\text {th }}\right) 321$; [Big M].

137 Cobaw, supra note 2 per Redlich J at para 545.

${ }^{138}$ Human Rights Code, RSO 1990, c H.19, section 35.

139 Brockie, supra note 132 at paras $33-35$.

${ }^{140}$ Brockie, supra note 132 at paras 47.
} 


\section{Critique of the Court of Appeal's approach to rights reconciliation}

There is a logical circularity in the Court's reasoning that cannot be resolved by its appeal to traditional models of statutory interpretation. The problem is most clear in the argument of Redlich $\mathrm{J}$ that the very inclusion of religious freedom guarantees in an equality guaranteeing statute indicates that the correct balance of rights has been struck between two competing values. How can the mere identification of two rights that require protection demonstrate the way decision-makers should balance these rights? A traditional statutory interpretation model answers this question by reference to the plain words in the statute. ${ }^{141}$

If there is no explicit limitation to the terms of 'religious freedom' in sections 75 and 77, then we must infer that Parliament intended these sections to be read as broadly as their natural meanings allow. This reasoning does not resolve questions about the breadth of ambiguous terms such as 'religious freedom' and 'religious expression'. They are not defined in the Equal Opportunity Act. Applying the standard rules of legislative interpretation and the authority of Momcilovic, ${ }^{142}$ as the Court of Appeal claims to do, recourse could therefore be had to human rights principles and cases from comparative jurisdictions that would assist in scoping the rights engaged. This was the submission made by the Victorian Commission and the International Council of Jurists.

The Court's reasoning seems to invite (through the reasons of Maxwell P and Neave JA) a supportive role for human rights principles in rights scoping, but this is not satisfactorily resolved, as there are no 'final' definitions of religious expression provided by the majority in the context of the exception provisions that either reflect or deny the international law principles relating to religious freedom and nor are there any concrete findings made on the relationship between equality rights and freedom of religion in the Equal Opportunity Act. Effectively, the majority resolved these questions by ruling out a substantive rights conflict on the basis of CYC's non-religious nature, thereby avoiding the issue of whether CYC's or Mr. Rowe's conduct was a legitimate exercise of freedom of religion in the circumstances.

\footnotetext{
${ }^{141}$ Acts Interpretation Act 1901 (Cth) section 15AA.

${ }^{142}$ Momcilovic, supra note 24.
} 
This failure to engage with the issue of 'how' to resolve a rights conflict is frustrating for future claims either to the protection of the religious exceptions or to parties seeking to demonstrate that they do not apply. The majority's rejection of a human rights limitations analysis (arguably one adapted from the Victorian Charter approach) led to the majority approaching each section of each provision with a separate emphasis on international legal principles and general equality law principles, without any guidance as to the procedural question of 'how rights conflict should be resolved'. The Court's decision therefore does not assist in defining clear boundaries for how religion and equality may interact in the public sphere.

The dissenting judgment is at least clear on the question of whether human rights principles apply (they do not) and to the question of when religious freedom may be exercised in a commercial context: Redlich J grants religious adherents considerable scope to exercise their right to religious expression in all aspects of their lives, including employment and commercial activities. What is unconvincing about the dissent, however, is its failure to engage with the proposed scope of equality rights in the public square, represented by the substantive protections set out in the Equal Opportunity Act. While the majority's holdings engage with the social value of equality and Parliament's intention to reflect this value in the legislation, Redlich J fails to give scope to this value in his consideration of the exception provisions. This leads back to the unsatisfactory conclusion that Parliament's intention as to 'how' to balance rights is made clear from the inclusion of a competing right: a statement that demonstrates the 'what' in terms of a value conflict, but not the 'how'. Redlich J's engagement with Canadian rights jurisprudence thus frustrates my analysis more than it clarifies: he flirts with the concepts of rights limitation and refers to frameworks that Courts might apply, but does not deal squarely with these frameworks or even the result of their application.

In conclusion, the rights frameworks described above, and the 'statutory interpretation' model preferred by the Australian courts to resolve conflicts of rights, are imperfect mechanisms for the complex and sensitive task of reconciling freedom of religion rights with equality rights. Particularly, as will be demonstrated in Chapters 2 and 3, the Australian approach lacks the clarity and cohesion of Canadian rights frameworks. While it is simplistic to assert that Australia could import wholesale the Canadian limitation and reconciliation tests (and there are 
constitutional and legislative bars to overcome), there are strong comparative arguments that demonstrate that, while social and political conditions are strikingly similar in Australia and Canada, legal approaches to rights limitation are not, and the balance is not in Australia's favour.

The arguments put in this Chapter also demonstrate that the challenge for anti-discrimination frameworks in Australia is that proponents for and opponents of the protection of religious freedom solely in this framework have fundamentally divergent views of the role of the liberal state. The discussion of whether a system of justice can balance freedom of religion rights and equality rights and, if so, how, should be at a more foundational level than a discussion about the merits of repealing or extending defence provisions in anti-discrimination law. This discussion should also not be a further extension of the debate about whether Australia should introduce a charter of rights, as this takes us to the 'how' before answering the 'what' and the 'why'. Australia requires a foundational debate about the role of religion within the liberal state. This debate could properly situate equality rights and freedom of religion and belief as separate and important human rights and analyse mechanisms for limiting their interaction in the public sphere. 


\section{CHAPTER 2}

\section{Freedom of religion and equality rights in Canada}

In this chapter, I analyse different tests and principles for either (a) reconciling or (b) limiting rights in cases where the right of freedom of religious expression and equality rights conflict. Canadian jurisprudence has developed different frameworks for reconciling a conflict of rights, depending on whether there is a direct challenge to a Charter right or by two rights relied on by individuals in a dispute.

This discussion is, for reasons of brevity, necessarily limited. This is regrettable, since there are multiple cases where Courts have considered different circumstances that demonstrate a 'clash' of rights or, to be less confrontational, a dual engagement of different rights. However, I have chosen to only focus on a range of cases that might be usefully contrasted with the Australian frameworks summarised in Chapter 1: namely those cases where there is an alleged breach of equality rights in the context of a claim of unlawful discrimination in an area of public life.

\section{Rights protection frameworks in Canada}

\section{(a) International obligations}

Like Australia, Canada is a signatory to both the ICCPR ${ }^{143}$ and the International Covenant on Economic, Social and Cultural Rights. ${ }^{144}$ The Canadian Bill of Rights ${ }^{145}$ and the Charter ${ }^{146}$ demonstrate the strong influence of international human rights norms, captured in the ICCPR and ICESCR, in the form of the rights protected in those documents. Further, a breach of Canada's

\footnotetext{
${ }^{143}$ ICCPR, supra note 55.

${ }^{144}$ International Covenant on Economic, Social and Cultural Rights (1966) United Nations Treaty Series vol. $993,3$.

145 Bill of Rights Act 1960 S.C. 1960 c. 44 [Bill of Rights].

${ }^{146}$ Charter, supra note 7.
} 
international commitments when Canadian officials or representatives act in foreign jurisdictions can trigger the extraterritorial application of the Charter. ${ }^{147}$

\section{(b) The Charter of Rights and Freedoms}

The Charter is a constitutionally entrenched bill of rights, which protects the rights and freedoms of all persons resident in Canada. Section 32 of the Charter provides that it applies to "the Parliament and government of Canada in respect of all matters within the authority of Parliament" and "to the legislature and government of each province in respect of all matters within the authority of the legislature of each province." The Supreme Court of Canada has confirmed that the Charter applies only to government and that government includes the legislative, executive and administrative branches. ${ }^{148}$ For the purposes of this discussion, it is important to note that 'government' also includes the actions of governmental officials in their treatment of individuals and the administrative decisions of government commissions, statutory authorities and tribunals, where these are made in accordance with statute. ${ }^{149}$

The Charter builds on the rights protected in the Canadian Bill of Rights, ${ }^{150}$ and the rights identified in the Charter can be catalogued into six broad divisions: fundamental freedoms, ${ }^{151}$ democratic rights, ${ }^{152}$ mobility rights, ${ }^{153}$ legal rights (notably pertaining to the criminal process and legal procedures), ${ }^{154}$ the right to equality, ${ }^{155}$ and language rights. ${ }^{156}$ Both equality rights and

\footnotetext{
${ }^{147} R$ v. Cook [1998] 2 S.C.R. 562, 164 D.L.R. (4th) 1. The Supreme Court of Canada considered whether the Charter could apply to police action where it found a breach of section 10(b) of the Charter by Canadian police acting to apprehend a Canadian citizen in the United States. The Supreme Court held that the Charter would apply outside of Canada where two conditions were met: the act fell within section 32(1) of the Charter and the application of the Charter would not generate 'an objectionable extraterritorial effect' by 'interfering with the sovereign authority of a foreign state' (at 25).

${ }^{148}$ R.W.D.S.U., Local $580 v$ Dolphin Delivery Ltd., [1986] 2. S.C.R. 573, 33 D.L.R. (4 $\left.4^{\text {th }}\right) 174$ at $194-195$ (D.L.R) [Dolphin Delivery].

${ }^{149}$ However, court orders are not subject to Charter application as these have been held not to constitute government action: ibid at para 196.

${ }^{150}$ Bill of Rights Act, supra note 145.

${ }^{151}$ Charter, supra note 7, section 2(a) - (f): conscience, religion, thought, belief, opinion, expression, assembly and association.

${ }^{152} \mathrm{Ibid}$ sections 3 - 5: the right to vote, the guarantee of regular elections and annual parliamentary sessions.

${ }^{153} \mathrm{Ibid}$, section 6.

${ }^{154} \mathrm{Ibid}$, sections 7 - 14: including the right to counsel, the right to protection against unreasonable search and seizure, habeas corpus, trial within a reasonable time the presumption of innocence until proven guilty, and the right to life, liberty and security of the person and right not to be arbitrarily deprived of liberty.

${ }^{155} \mathrm{Ibid}$, section 15.

${ }^{156} \mathrm{Ibid}$, sections $16-23$.
} 
freedom of religion may be subject to the 'notwithstanding' clause in section $33,{ }^{157}$ and the limitations clause in section 1 applies to all Charter rights.

Determination of the application of rights and freedoms in the Charter to law is the task of judicial review. In 1982, the Canadian Constitution was amended to include an explicit supremacy clause, that provides that the constitution, including the Charter, is the supreme law of Canada, and any law that is inconsistent is, to the extent of the inconsistency, of no force and effect. ${ }^{158}$ As Robert Sharpe and Kent Roach note, the role of the Court in interpreting and applying the Charter has been controversial, as the result of a Charter decision may bind successive parliaments at both federal and provincial level, unless there is resort to the override clause in section 33 or a law is found to satisfy the test in section 1. "Hence, a Charter decision can have a much more telling impact upon the scope for legislative choice" ${ }^{159}$ than alternative models of rights protection where the decisions of Parliament on the question of rights protection are final. This model of statutory protection for rights (as opposed to constitutional) was introduced in Canada in the Bill of Rights Act in 1960. Sharpe and Roach identify two key defects of the Bill of Rights Act. First, it applies only to federal laws, meaning that the actions of provincial legislatures and those acting under provincial authority were immune from its application. Second, as an ordinary Act of Parliament, the mandate conferred upon courts to adjudicate breaches of rights was limited. "Judges were reluctant to find that Parliament had authorized them to invalidate other duly elected laws."160

The practice of judicial review at this level, and the level of 'dialogue' that exists between parliament and the judiciary within the Charter framework, has been the focus of much academic and popular debate. ${ }^{161}$ It is possible for a court decision to trump a legislative decision of an elected parliament and to invalidate its legislation on the basis of a 'counter-majoritarian

\footnotetext{
157 Charter, supra note 7, section 33 relevantly provides: "Parliament or a provincial legislature may declare that a law shall operate "notwithstanding" a provision included in section 2 or sections 7 to 15 of the Charter."

${ }^{158}$ Constitution Act, supra note 7 at section 52(1).

${ }^{159}$ Robert J. Sharpe and Kent Roach, The Charter of Rights and Freedoms, (Toronto, Irwin Law Inc. 2009 ) at 28.

${ }^{160} \mathrm{Ibid}$, at 17.

${ }^{161}$ See: Peter W. Hogg and Allison A. Bushell, "The Charter Dialogue Between Courts and Legislatures (Or Perhaps the Charter of Rights isn't Such a Bad Thing After All)", 1997, 35 Osgoode Hall L.J. 75; Peter W. Hogg, Allison A. Bushell Thornton and Wade K. Wright, "Charter Dialogue Revisited - Or 'Much Ado About Metaphors” 200745 Osgoode Hall L.J. 2.
} 
view, ${ }^{162}$ or at least a view of social policy and the validity of rights that is not settled and generates political controversy. For example, in the cases of EGALE Canada Inc. v Canada (Attorney General), ${ }^{163}$ Halpern v Canada ${ }^{164}$ and Hendricks v Quebec, ${ }^{165}$ the Supreme Courts of British Columbia, Ontario and Quebec (respectively) determined that there was a breach of section 15 Charter rights in relation to the common law and provincial statutes' requirement that marriage be between two people of the opposite sex.

Some commentators view such a 'dialogue' between superior courts and the elected government as demonstrating the success of the model. Rosalind Dixon summarises the argument for the dialogue model of Charter review as suggesting that Canada has supported a 'halfway house' between the strong form of judicial review typified by judicial review in the United States and the previous legislative supremacy (or statutory) model embodied in the Bill of Rights:

By describing the possibility of an ongoing exchange between courts and legislatures in their interpretations of the Charter, dialogue as a metaphor clearly points to a potential midway path between the extremes of both legislative and judicial finality. ${ }^{166}$

There are anxieties about the degree to which the 'Dialogue Model' of rights interpretation under the Charter works to promote democratic principles in significant issues of public policy; however the debate about the role of the judiciary within a representative democratic system is not the focus of this discussion. For my purposes, is sufficient to note that the Charter has constitutional authority over other laws, that the responsibility for determining constitutional validity of law on Charter grounds vests with the judiciary, and that there is ongoing tension between acceptance of the constitutional model of rights protection and other principles of democratic government.

\footnotetext{
162 Rosalind Dixon, "The Supreme Court of Canada, Charter Dialogue and Deference", 2009, 47, Osgoode Hall L.J, $235-286$, p. 237.

${ }^{163}$ EGALE Canada Inc. v Canada (Attorney-General) (2003) 225 D.L.R. $\left(4^{\text {th }}\right)$.

${ }^{164}$ Halpern v Canada (Attorney-General) (2003) 65 O.R. $\left(3^{\text {rd }}\right)$.

${ }^{165}$ Hendricks v Quebec (Procureur General) [2002] R.J.Q. 2506.

${ }^{166}$ Dixon, supra note 162 at 239.
} 


\section{(c) Human rights legislation}

Human rights legislation that prohibits discrimination in areas of public life are in force in every Canadian jurisdiction, from the federal Canadian Human Rights Act to human rights codes and Acts in every province and territory. ${ }^{167}$ Human rights codes were first enacted at a provincial level and initially provided protection against racial and religious discrimination. ${ }^{168}$ The evolution of human rights legislation in Canada is similar to that of Australia: in that initial narrow grounds of protection have gradually been expanded to include different personal characteristics that form the basis of unlawful discrimination, where those characteristics have been the cause (or one of the causes) of a disadvantage, adverse treatment, or detriment. Jurisdiction of human rights Acts and Codes is determined by the constitutional division of powers. Therefore, complaints involving banking, national airlines, railways, or federal government employees are in the federal jurisdiction, whereas complaints involving school boards, city government, or restaurants are in the provincial jurisdiction. ${ }^{169}$ Human rights Acts generally apply to a broader class of respondent than the Charter: in all jurisdictions, the actions of private individuals can be the basis for a discrimination complaint, provided those actions (or omissions) occurred in an area of public life protected by the legislation. The Charter, by comparison, has very limited application to private actions.

In some cases, however, the Charter and human rights legislation operates in tandem to increase and clarify rights protection. In Vriend v Alberta $^{170}$ (Vriend) the Charter challenge concerned the actions of a private school who refused to hire gay teachers. As a private entity, the school was not subject to the Charter, had to comply with Alberta's anti-discrimination legislation. The Supreme Court of Canada held that the application of the anti-discrimination legislation violated the complainant's Charter section 15 right to equality, and extended the operate of the legislation to include sexual orientation as a new prohibited ground of discrimination.

Human rights legislation, at a provincial and federal level, has been recognised by the Supreme Court of Canada as having 'quasi constitutional status' such that laws should generally be read

\footnotetext{
167 Sharpe and Roach, supra note 159 at 15.

168 Ibid.

${ }^{169}$ Canadian Human Rights Reporter, "Human Rights Law Primer: Human Rights Law Basics” (updated 2013), available online: http://www.cdn-hr-reporter.ca/content/human-rights-law-basics

${ }^{170}$ Vriend v Alberta [1998] 1 S.C.R. 493, 156 D.L.R. (4th) 385 (Vriend).
} 
consistently with that legislation. ${ }^{171}$ Provinces such as Ontario have reflected this fundamental importance of human rights Acts by including a primacy clause in the legislation, granting the Act the ability to trump other provincial legislation. ${ }^{172}$ Therefore, rather than being diminished by the Charter, human rights legislation maintains an important role in the development of rights jurisprudence and community understanding of rights. Further, the Supreme Court of Canada and human rights commissions have noted that developments in different human rights jurisdictions influence one another, particularly in terms of scoping rights protection and dealing with conflicts between rights. ${ }^{173}$ As in Australia, every human rights jurisdiction in Canada protects the individual against discrimination on the basis of religious belief in some form. ${ }^{174}$

\section{Scope of rights: Freedom of religion, conscience and belief}

The guarantee of religious freedom in section 2(a) of the Charter is a broad guarantee of religious liberty:

Everyone has the following fundamental freedoms:

(a) freedom of conscience and religion. ${ }^{175}$

The definition of 'freedom of conscience, religion and belief' in section 2(a) was first considered by the Supreme Court of Canada in Big M. ${ }^{176}$ Dickson CJ for construed religious freedom broadly as protecting the right of an individual to be:

free to hold and to manifest whatever beliefs and opinions his or her conscience dictates, provided inter alia only that such manifestations do not injure his or her neighbours or their parallel rights to hold and manifest beliefs and opinions of their own. ${ }^{177}$

The Court revisited the scope of religious freedom in Edward Books \& Art Ltd $v$ R (Edward

\footnotetext{
${ }^{171}$ Simpsons-Sears Ltd v. Ontario (Human Rights Commission) [1985] 2 S.C.R. 536, 23 D.L.R. (4th) 321; Canada (Human Rights Commission of Canada) v Taylor, [1990] 3 S.C.R. 892 (Taylor) per Dickson CJ at 920. See also: Julian Walker, (Parliamentary Information and Research Service), Canadian Anti-Hate Laws and Freedom of Expression, Background Paper, Parliamentary Library (Ottawa), 2010-31-E, 1 September 2010 (revised 27 March 2013) (Walker) 5, online: http://www.parl.gc.ca/Content/LOP/ResearchPublications/2010-31-e.pdf

172 Ontario Human Rights Code, section 3.

173 Ontario Human Rights Commission, "Policy on competing Human Rights", (2010), online, 20.

${ }^{174}$ Anne-Marie Mooney Cotter, Heaven Forbid: An International Legal Analysis of Religious Discrimination (New York, Ashgate Publishing House, 2006), chapter 6, pp. 131 - 144.

${ }^{175}$ Charter, section 2(a).

${ }^{176}$ R. v Big $M$, supra note 136.

177 Ibid, at 336.
} 
Books). ${ }^{178}$ In Edward Books, Chief Justice Dickson again emphasised the individual, subjective and libertarian aspects of freedom of religious expression under the Charter:

[T] he purpose of section 2(a) is to ensure that society does not interfere with profoundly personal beliefs that govern one's perception of oneself, humankind, nature, and, in some cases, a higher or different order of being. These beliefs, in turn, govern one's conduct and practices. ${ }^{179}$

The Australian High Court's concern about metaphysical aspects of a 'religion' and an explicit link with doctrine or practice is not emphasised in Canadian jurisprudence. Rather, the test for a breach of section 2(a) is whether there is a sincere belief in a religious doctrine or principle and whether that belief (or a manifestation of that belief) has been limited or affected by a state action or law. ${ }^{180}$

In more recent cases where the Court has considered the relevance of religious doctrine to the act of religious expression, the Supreme Court of Canada has preferred a broad and (relatively) subjective view of religious practice and belief, emphasising that the Charter supports a "subjective conception of freedom of religion, one that is integrally linked with an individual's self-definition and fulfillment and is a function of personal autonomy and choice". ${ }^{181}$ In Amselem the Court preferred a subjective test of sincere belief of the adherent in terms of assessing the significance of a religious practice (expression) to an adherent:

Freedom of religion consists of the freedom to undertake practices and harbour beliefs, having a nexus with religion, in which an individual demonstrates that he or she sincerely believes or is sincerely undertaking in order to connect with the divine or as a function of his or her spiritual faith, irrespective of whether a particular practice or belief is required by official religious dogma or is in conformity with the position of religious officials. ${ }^{182}$

The Supreme Court of Canada's firm adherence to a broad reading of section 2(a) is clear in those cases where the religious belief at issue is weighed against a non-right based state policy or

\footnotetext{
${ }^{178}$ Edwards Books \& Art Ltd v R. [1986] 2 S.C.R. 713, 35 D.L.R. (4 $\left.{ }^{\text {th }}\right) 1$ [Edward Books].

${ }^{179}$ Ibid, per Dickson CJ at 759.

${ }^{180}$ Sharpe and Roach, supra note 159 at 131.

181 Syndicat Northcrest v Amselem 2004 SCC 47, [2004] 2 S.C.R. 551 at 42 [Amselem]. Cf: R v N.S 2012 SCC 72.

182 Amselem, ibid, at 46.
} 
interest that aims to limit the right in section 2(a). The Court will emphasise the breadth and individual nature of religious belief and that the Court prefers to give it an expansive reading. This reflects the long significance of religious expression in Canadian public life. ${ }^{183}$

\section{Scope of rights: Equality rights}

Section 15(1) of the Charter contains a guarantee of equality for all persons:

Every individual is equal before and under the law and has the right to the equal protection and equal benefit of the law without discrimination and, in particular, without discrimination based on race, national or ethnic origin, colour, religion, sex, age or mental or physical disability.

The scope of section 15(1) is greater than the more limited equality guarantee set out in section 1(b) of the Canadian Bill of Rights, ${ }^{184}$ and was famously described as reflecting "the fondest dreams, the highest hopes and finest aspirations of Canadian society" ${ }^{185}$ as a constitutional statement of equality rights and a broad prohibition on discrimination. ${ }^{186}$ Justice Cory echoed Chief Justice Dixon's sentiments in Keegstra ${ }^{187}$ and Taylor ${ }^{188}$ that the guarantee of equality before and under the law, and freedom from discrimination, was in fact the "foundation for a just society". 189

In Andrews v. Law Society of British Columbia ${ }^{190}$ (Andrews), the first decision of the Supreme Court of Canada to consider section 15 of the Charter, the Court indicated that, in deciding whether a distinction was discriminatory, it would analyse the legislative purpose of the

\footnotetext{
${ }^{183}$ See: Marguerite Van Die, Religion and Public Life in Canada - Historical and Comparative Perspectives (Toronto, University of Toronto Press, 2001); Alex Fielding, "When Rights Collide: Liberalism, Pluralism and Freedom of Religion in Canada" 200813 Appeal 28 at 29.

${ }^{184}$ Bill of Rights Act, supra note 145, section 1(b) guarantees "the right to equality before the law and the protection of the law".

${ }^{185}$ Vriend, supra note 170 per Justice Cory at para 67.

${ }^{186}$ Sharpe and Roach comment that the insistence in 'the careful wording of section 15 that the guarantee includes equality before and under the law, as well as equal protection and equal benefit of the law, was meant to signal to the courts that section 15 was intended to be a much more powerful instrument of protection than its predecessor."

Sharpe and Roach, supra note 159 at 310.

${ }^{187} R$ v. Keegstra [1990] 3 S.C.R. 697 [Keegstra].

${ }^{188}$ Taylor, supra note 171.

${ }^{189}$ Vriend supra note 187.

${ }^{190}$ Andrews v. Law Society of British Columbia [1989] 1 S.C.R. 143 [Andrews].
} 
distinction, however it would also go further and consider the impacts of laws on a group claiming section 15 protection. ${ }^{191}$

The prevailing view, however, is that the Supreme Court of Canada has been overly cautious and formalistic in its approach to Charter equality rights claims and that the promise of a substantive concept of equality as a human rights norm has not been realised. ${ }^{192}$ Carissima Mathen argues that equality decisions over the last thirty years have rendered "section 15 an unstable platform for equality litigation. ${ }^{193}$ Mathen analyses the effect of section 15 jurisprudence from Andrews ${ }^{194}$ to R. v. Kapp ${ }^{195}$ and concludes that the Supreme Court of Canada has taken a highly formalized and rigid approach to Charter equality rights that makes it very difficult for claimants to succeed in demonstrating prima facie discrimination. This formalized approach insists on a comparator test, that the claimed benefit accord with the purpose and design of the law and that any alleged discrimination "be cognizable to a reasonable person." 196 Mathen notes that recent section 15 cases display increasing latitude given to governments to demonstrate reasonable limitations on equality rights under section 1 of the Charter. ${ }^{197}$

Mathen argues that, by comparison, the Supreme Court of Canada has preferred a straightforward test for a breach of religious freedom under section 2(a) and has required a "rigorous analysis of justification" for a legislative breach. Mathen argues that, in its approach to section 2(a), the Supreme Court of Canada has given real voice to a purposive reading of the scope of religious freedom and has focused on the right of the individual and preferred a subjective view of religious belief and practice and has generally required governments to 'offer compelling justifications for rights infringements' under section $1 .{ }^{198}$

\footnotetext{
191 Andrews, supra note 190 per McIntyre J at para 175.

192 See: Sheilah Martin, "Balancing Individual Rights to Equality and Social Goals", 2001, Can. Bar. Rev. 299 - 373; David M. Beatty, "The Canadian Conception of Equality", 1996, 46, U.T.L.J., 3, 439 - 374.

193 Carissima Mathen, "What Religious Freedom Jurisprudence Reveals About Equality”, 2008 - 2009, J.L \& Equal. $163-200$ at 164.

194 Andrews, supra note 190.

${ }^{195}$ R. v. Kapp 2008 SCC 41 [Kapp].

${ }^{196}$ Mathen notes that, in Kapp, the Court appeared to promote a concept of substantive equality in its recognition of ameliorative programs under section 15(2). Mathen commented that "it is too early to determine Kapp's precise impact on equality analysis." Mathen, supra note 193 at 164, fn. 4.

197 Ibid, at 164.

198 Ibid.
} 
My analysis of equality rights must go beyond an analysis of rights protected under section 15 of the Charter. This is because principles of equality, multiculturalism, diversity and tolerance have been referred to by Canadian courts as fundamental values which sit both within and above legislative statements of equality guarantees. For example, in Keegstra, ${ }^{199}$ the Supreme Court of Canada considered the rights at play in section 319(2) of the Criminal Code ${ }^{200}$ and weighed the 'social value' of equality and multiculturalism in Canadian society and the significance of international human rights obligations undertaken by Canada that aimed at eradicating discrimination. Similarly, in Taylor, ${ }^{201}$ his Honour Chief Justice Dickson, when considering the validity of section 13 of the Canadian Human Rights $A c t^{202}$ again stressed the significance of Canada's international obligations to promote equality and eliminate discrimination as informing Parliament's objective to prevent the dissemination of race propaganda, with a particular emphasis on the need to protect vulnerable groups: "a meaningful consideration of the principles central to a free and democratic society requires reference to the international community's acceptance of the need to protect minority groups. ${ }^{203}$ His Honour stated:

[T] he values of equality and multiculturalism... magnify the weightiness of Parliament's objective in enacting section 13(1) [of the Canadian Human Rights Act]. [G]uiding principles in undertaking the section 1 inquiry include respect and concern for the dignity and equality of the individual and a recognition that one's concept of self may in large part be a function of membership of a particular cultural group. ${ }^{204}$

Key to the Court's reasoning in these balancing exercises is that 'equality' exists as a right, interest and value in Canadian public life beyond legislative and constitutional guarantees of equality and freedom from discrimination. Further, it seems that the Supreme Court of Canada holds the view that the principle of equality is closely aligned with (if not indivisible from) the values of multiculturalism, pluralism and human dignity, and this broad understanding of equality should be preferred in balancing exercises taken in terms of the section 1 analysis in cases considering human rights legislation. This broad view further strengthens the nature of human rights legislation as quasi-constitutional.

\footnotetext{
199 Keegstra, supra note 187.

${ }^{200}$ Criminal Code SC 1985, c C-46, section 319(2).

${ }^{201}$ Taylor, supra note 171.

${ }^{202}$ Canadian Human Rights Act, RSC, 1985, c H-6. [Canadian Human Rights Act].

${ }^{203}$ Taylor, supra note 171 per Dickson CJ at paras $917-918$.

${ }^{204}$ Taylor, supra note 171 per Dickson CJ at paras 920.
} 


\section{General principles for resolving rights conflict: overview}

The principles discussed below are not merely Charter specific, rather they represent the highest level of rights analysis in Canada, and create principles that can influence human rights jurisprudence in different jurisdictions. As the Ontario Human Rights Commission notes in its Policy on Competing Human Rights, while many of these legal principles were determined in Charter litigation, they provide guidance for other types of human rights conflict, including where two rights conflict in a provincial human rights Code dispute. ${ }^{205}$

Several of these principles discussed below were reflected in intervenor submissions in the Cobaw decision, including the Victorian Human Rights and Equal Opportunity Commission, in relation to the 'proper delineation and scope' of competing rights within a discrimination law context. The 'shared' principles between Canadian jurisprudence and intervenor submissions in Cobaw are: that no Charter rights are absolute and may all be reasonably limited, that there is no 'hierarchy' of rights and that rights conflicts cannot be determined in the abstract or in a "factual vacuum". However, while the intervenor submissions in Cobaw noted that these principles also reflect leading international law jurisprudence on conflict of rights issues, they did not expressly reference Canadian case law or guiding commentary on the Canadian Supreme Court's approach to conflicting rights in discrimination law matters.

The principles discussed below have been targeted at freedom of religion cases and, where possible, in those cases where freedom of religion conflicts with equality rights. I argue that the Court's approach to rights balancing under section 1 of the Charter is more nuanced (at this stage in the jurisprudence) than its approach to reconciling rights conflict between individual actors. However, I also contend that there is significant overlap in aspects of the tests, and therefore the principles summarised below will be relevant to both forms of rights limitations analysis.

205 Ontario Human Rights Commission, Policy on Competing Human Rights (2010) online: http://www.ohrc.on.ca/en/policy-competing-human-rights at para 20 ["Policy on Competing Rights"] (last accessed: 27 July 2014). 


\section{(a) No Charter right is absolute}

His Honour Iacobucci has stated that "[a] particular Charter right must be defined in relation to other rights and with a view to the underlying context in which the apparent conflict arises."206 Further, in $R v$ Mills, ${ }^{207}$ Iacobucci and McLachlin JJ (as she then was) held that, in relation to the desired reconciliation of rights, "no single principle is absolute and capable of trumping the others; all must be defined in light of competing claims." ${ }^{208}$

\section{(b) No hierarchy of Charter rights}

Applying the above principle, there is no hierarchy of rights operating within the Charter and it therefore follows that one should not be inferred from Charter jurisprudence. Professor Peter Hogg has argued that the operation of section 33 of the Charter has in fact created two tiers of rights: "the common rights that are subject to override and the privileged rights that are not."209 Both section 2(a) and section 15 are subject to override by operation of section 33 of the Charter. However, as Justice Iacobucci notes, Professor Hogg further explains that the hierarchy of Charter rights that he presents reflects the differences in the "vulnerability of the right to legislative abridgement." However, it does not follow that the privileged rights take priority over the common rights when they conflict. ${ }^{210}$

The authority for the principle that no hierarchy of rights is to be inferred from Charter interpretation and judicial analysis is Dagenais v Canadian Broadcasting Corporation (Dagenais). ${ }^{211}$ Related to this concept of the prohibition of a hierarchy of rights, in Dagenais, his honour Chief Justice Lamer stated that:

When the protected rights of two individuals come into conflict, as can occur in the case of publication bans, Charter principles require a balance to be achieved that fully respects the importance of both sets of rights. ${ }^{212}$

\footnotetext{
206 The Honourable Justice Frank Iacobucci, “Reconciling Rights' - The Supreme Court of Canada's Approach to Competing Charter Rights" (2003) 20 S.C.L.R. (2d) 137 at 138; see also: $R v$ Creighton [1995] 1 S.C.R. 858 at 34. 


\section{(c) The Charter must be read holistically}

The Charter must be interpreted as a "unified whole", applying a general rule of constitutional interpretation. ${ }^{213}$ Iacobucci J notes that, in the case of Trinity Western University v. British Columbia College of Teachers, ${ }^{214}$ the Supreme Court of Canada reaffirmed this principle in the context of holding that "one right is not privileged at the expense of another." 215 This case is discussed at length in Chapter 3. Iacobucci J states that, while this appears to be a conflicting statement (in the context of an attempt to resolve a conflict of rights), it is important for courts considering Charter rights to apply this principle as in other constitutional cases. This is because, while "many would argue that it is not the role of courts to make normative judgments about which rights should be prioritized at the expense of others... it is proper for courts to give the fullest possible expression to all relevant Charter rights, having regard to the broader factual context and to the other constitutional values at stake."216

\section{(d) Rights cannot be weighed in the abstract}

Further, in considering how to weigh rights, courts should consider the full context, facts and constitutional values at play and there should be an emphasis on the resolution of the rights conflict before the Court, rather than addressing a hypothetical conflict. In Reference Same Sex Marriage (Re), ${ }^{217}$ the Supreme Court of Canada held that Charter rights cannot be determined in the abstract, as the operation of rights must be examined in context in order to settle a conflict between competing rights. Further, "courts must be acutely sensitive to context, and approach the Charter analysis flexibly with a view to giving the fullest possible expression to all the rights involved." 218

In terms of section 2(a), the Court considered three arguments that the Proposed Act would, in its effect, limit freedom of religion: first, that it would have the effect of imposing a dominant social ethos that will discourage people from holding different religious beliefs; second, that it will

\footnotetext{
213 Iacubucci J, supra note 206 at 140.

2142001 SCC 31, [2001] 1 S.C.R. 772 [Trinity Western].

215 Ibid, at para 31.

${ }^{216}$ Iacobucci J, supra note 206 at 140.

${ }^{217}$ Re Reference Same Sex Marriage 2004 SCC 79 [Same Sex Marriage].

218 Ontario Human Rights Commission, Policy on Competing Rights, supra note 205 at para 5.4.1; see also: Iacobucci J, supra note 206 at 140.
} 
force religious officials to perform same-sex marriages, and third, that it will create a 'collision of rights' in areas of public life beyond the solemnisation of marriage.

The Court noted that the Proposed Act only applied to civil marriage, not religious marriage. The Court held that a law that required religious officials to perform same-sex marriages would breach section 2(a) of the Charter as this would constitute state compulsion on religious officials to perform same-sex marriages contrary to their religious beliefs. The Court also stated that "absent exceptional circumstances which we cannot at present foresee, such a violation could not be justified under section 1 of the Charter." 219

However, the Court then stopped short of determining whether there was, in this case, a conflict of rights that would affect the interests of religious groups and/or same-sex couples. The Court relied on the fact that the Proposed Act had not yet been implemented and therefore, at this stage, the conflict of rights was "purely abstract". ${ }^{220}$ The Court emphasised its view that "Charter decisions should not and must not be made in a factual vacuum."221 The Court also noted that most "conflicts of rights do not imply conflict with the Charter, rather the resolution of such conflicts generally occurs within the ambit of the Charter itself by way of internal balancing and delineation." 222

\section{(e) Courts should balance relevant rights with applicable societal values}

Justice Iacubucci considers that the appropriate place for this assessment is as part of the section 1 proportionality analysis. ${ }^{223}$ The significance of 'societal values and principles' is a hallmark of section 1 analysis, as stated by Chief Justice Dickson in Oakes:

The Court must be guided by the values and principles essential to a free and democratic society which I believe embody, to name but a few, respect for the inherent dignity of the human person, commitment to social justice and equality, accommodation of a wide variety of beliefs, respect for cultural and group identity and faith in social and political institutions which enhance the participation of individuals and groups in society. ${ }^{224}$

\footnotetext{
219 Same-Sex Marriage supra note 217 at para 58.

${ }^{220} \mathrm{Ibid}$, at para 51.

${ }^{221}$ Ibid, at para 51, quoting: unanimous Court judgment in MacKay v Manitoba [1989] 2 S.C.R. 357 at 361.

${ }^{222} \mathrm{Ibid}$ at para 52.

${ }^{223}$ Iacobucci J, supra note 206 at $142-143$.

${ }^{224}$ R. v. Oakes [1986] 1 S.C.R. 103, 26 D.L.R. (4th) 200 per Dickson CJ, at 103 [Oakes].
} 
The difficulty with placing the 'balancing' exercise of societal values with Charter rights only in the context of section 1 is that the Court has explicitly stated that the proper assessment of competing rights should take place in the scoping exercise of the rights and that, in many cases, a section 1 analysis will not be appropriate, as this will determine a 'rights trump' scenario. Justice Iacubucci comments:

The exercise in which courts engage when they define the content and scope of rights in relation to one another, more closely approximates rights "reconciliation" than rights "balancing". The latter term, which connotes assigning primacy to one right over another right or interest having weighed the relevant considerations is customarily used in section 1 Oakes test jurisprudence and is perhaps better suited to that sort of analysis. ${ }^{225}$

An example of when the Supreme Court of Canada has explicitly dealt with societal values of equality and non-discrimination is Bruker v Marcovitz. ${ }^{226}$ Here, the Supreme Court of Canada resolved a dispute whereby a Jewish husband had refused to grant his wife a religious divorce or 'get' for 15 years, despite this being one of the conditions of a settlement agreement following the breakdown of their marriage. Mr. Marcovitz claimed that he had a religious right to refuse the request for a divorce and that to enforce the conciliation agreement would involve a breach of his right of religious freedom under section 2(a) of the Charter. A majority of the Court held that Mr. Marcovitz was not protected from liability for breaching the agreement on the basis of freedom of religion and that his rights were outweighed because:

[T] he public interest in protecting equality rights, the dignity of Jewish women in their independent ability to divorce and remarry as well as the public benefit in enforcing valid and binding contractual relations, are among the interests and values that outweigh $\mathrm{Mr}$. Marcovitz's claim that enforcing [the agreement] would interfere with his religious freedom. ${ }^{227}$

\section{(f) 'Core' of a right is more protected than its periphery}

In religious freedom cases, courts have held that the further the activity is from the core elements of religious freedom (and the religious belief), the more likely an activity is to impact on others

\footnotetext{
${ }^{225}$ Iacobucci J, supra note 206 at 141.

${ }^{226}$ Bruker v Marcovitz 2007 SCC 54, [2007] 3 S.C.R. 607.

${ }^{227} \mathrm{Ibid}$, per Abella $\mathrm{J}$ at para 92.
} 
and the less deserving the activity is of protection. ${ }^{228}$ In the case of Brockie $^{229}$ the Ontario Divisional Court held that Mr. Brockie held a religious belief as a Christian that homosexuality is immoral and should not be promoted. However, his refusal to print pamphlets for a LGBTI agency in his commercial printing business was a direct limitation on the equality rights of others to be free from discrimination on the basis of sexual orientation and was not upheld as a lawful expression. Further, the link between Mr. Brockie's religious belief and his commercial activities was "at best, at the fringes of the right." 230 The case of Brockie was discussed in more detail in Chapter 1, in the context of Justice Redlich's analysis of rights balancing in Cobaw.

\section{(g) Respect importance of both sets of rights at play}

Charter principles require courts to prefer an approach that respects the importance of both sets of rights as much as possible, while still acknowledging need to engage in constructive compromises where this is necessary in the context of the dispute. The Ontario Human Rights Commission has commented that the process of looking for options to reconcile competing human rights may well resemble a section 1 Charter balancing analysis. ${ }^{231}$ The Courts also recognise that there will be cases where there is no way to reconcile the competing rights at issue and there must be an outcome which respects one set of rights at the expense of another.

For example, in R. v. N.S. ${ }^{232}$ a majority of the Supreme Court of Canada held that the religious right of a Muslim woman to wear the niqab during a trial conflicted with the defendant's right to a fair trial, including the right to make a full answer and defence (sections 7 and 11(d) of the Charter) and the right to a fair trial prevailed. Writing for the majority, McLachlin CJ held that the right to religious freedom must, in these circumstances, yield to the countervailing right as "our justice system has always held that the threat of convincing an innocent person strikes at the heart of the principles of fundamental justice." 233

\footnotetext{
${ }^{228}$ Brockie, supra note 132 at para 51.

229 Ibid.

${ }^{230}$ Ibid at 56.

${ }^{231}$ Ontario Human Rights Commission, Competing Rights Policy, supra note 207 at para 5.7.

${ }^{232}$ R. v. N.S. 2012 SCC 72 [N.S].

${ }^{233}$ Ibid per McLachlin CJ at paras $88-89$.
} 


\section{Tests to balance and limit rights}

\section{The Oakes test}

Section 1 of the Charter allows governments to set reasonable limits on Charter rights of individuals, ensuring that no Charter right is unlimited:

The Canadian Charter of Rights and Freedoms guarantees the rights and freedoms set out in it subject only to such reasonable limits prescribed by law as can be demonstrably justified in a free and democratic society. ${ }^{234}$

Section 1 presupposes that other values could be 'prescribed by law' to the extent that they limit rights and may limit Charter rights to the extent that such limitations can be justified within a 'free and democratic society'. What is meant by the term 'free and democratic', including whether this involves an assessment of social change and contemporary attitudes, has been a subject of ongoing debate by the Supreme Court and legal commentators. ${ }^{235}$ In $R v$ Oakes, ${ }^{236}$ the Supreme Court set out a four stage test to determining whether a breach of a Charter right is reasonable. ${ }^{237}$ While later cases refined the Court's approach to the Oakes test and focused on different limbs of the test to interrogate limitations on rights, its fundamental limbs have remained unchanged. To summarise the Oakes test, ${ }^{238}$ we can say that a right may be reasonably limited under section 1 of the Charter where:

1. The objective of the measure is 'pressing and substantial' and warrants overriding a charter right.

2. There must be a rational connection between the limit on the right and the objective sought.

3. The limit should be minimally impairing.

\footnotetext{
${ }^{234}$ Charter, supra note 7 , section 1.

${ }^{235}$ For example, see Mark Antaki's thoughtful analysis of Charter and social 'values' in modern society through the lens of section 1 and the Oakes test: Mark Antaki, "The Turn to 'Values' in Canadian Constitutional Law" in Luc. B. Tremblay and Gregoire C. N. Webber Eds, The Limitation of Charter Rights: critical essays on R v Oakes, (Editions Themis, Montreal, 2009), pp. 155 - 180.

236 Oakes, supra note 224.

${ }^{237}$ An initial step is determining that a limitation (legislative or administrative) is 'prescribed by law'. As this assessment is not strictly relevant to the subject discussed here, I have not gone into detail in assessing the requirements for 'prescribed by law', but note that the Court has generally applied a relaxed or broad standard, and included a common law rule or regulation in addition to legislation or administrative decisions: Irwin Toy Ltd v Quebec [1989] 1 S.C.R. 927.

238 Oakes supra note 224, per Dickson CJ at paras $69-70$.
} 
4. Where there is an overall balance between the benefits of the limit and its deleterious effects on the Charter right engaged. ${ }^{239}$

As with other legislative defence clauses, the appellant bears the burden of alleging a breach of a Charter right and the State has the onus of demonstrating that the requirements of section 1 is met. ${ }^{240}$ The Supreme Court has mandated that section 1 involves an assessment of the external limits of rights that is the necessary second step to establish an unlawful breach of Charter rights. In the first instance, the Court must assess whether there has been a breach of a Charter right, with reference to the plain language of the right, the factual and social context, and relevant jurisprudence. Sometimes this first stage includes controversial reasoning about the content of a protected right, for example the inclusion of hateful speech within the broad category of freedom of expression. ${ }^{241}$ This step is where the analysis can diverge between the 'reconciliation' exercise and the balancing exercise under the Oakes test.

In Oakes, the Court did not explicitly discuss those cases where a 'pressing and substantial' objective intended to limit a right would have the character of another Charter right. In many Charter cases where the section 1 analysis is central to the finding, the issue is resolving rightslimiting legislation with the substantive protections of the Charter, without consideration of an opposing Charter right. In these cases, the Court's analysis focuses on whether a legislative measure may lawfully limit the right to religious expression on the basis that its objective (a nonCharter or human rights value) is pressing and substantial. This is (arguably) a more straightforward form of analysis than where the Court must balance two competing rights by determining their content and form and the degree to which they may limit each other in a free and democratic society.

Although the section 1 analysis strictly applies to the limitations of protected rights and to circumstances where there is an allegation of a limit of a right by a measure 'prescribed by law',

\footnotetext{
239 Alan Brudner, "What Theory of Rights Best Explains the Oakes test?" in Tremblay and Webber Eds, The Limitation of Charter Rights, supra note 235 at 59.

${ }^{240}$ Big M, supra note 136 per Dickson J at para 139.

${ }^{241}$ Keegstra, supra note 187; see also Saskatchewan (Human Rights Commission) v. Whatcott 2013 SCC 11, [2013] 1 SCR 467 [Whatcott].
} 
in several cases the Court has been required to balance conflict rights within the context of the section 1 assessment. In so doing, the Court has pronounced on issues to do with the lawful curtailment of freedom of religious expression and the promotion of equality and diversity within Canadian society. The Court's application of the Oakes test in freedom of religion and equality rights cases is discussed further in Chapter 3.

\section{II 'Reconciling' approach to achieving a resolution of rights}

In Dagenais, ${ }^{242}$ the Supreme Court of Canada applied the general guiding principles to a conflict of rights case that engaged the right to freedom of expression in section 2(b) of the Charter with the right to full answer and defence. ${ }^{243}$ The Supreme Court asked the following questions to determine how to appropriately balance the Charter rights engaged: ${ }^{244}$

1. Is the limitation on the right 'necessary' to prevent a real and substantial risk to the enjoyment of the other right; and

2. Will the salutary effects of the publication ban outweigh the deleterious effects to the competing right? ${ }^{245}$

The Supreme Court of Canada acknowledged that this framework reflects aspects of the substance of the Oakes test when assessing legislation under section 1 of the Charter. In particular, the Court noted, the substance of this test draws on the third limb of the Oakes test, the proportionality assessment limb. ${ }^{246}$ The proportionality assessment undertaken in relation to the effects of the limitation might seem at odds with the principle that the purpose of limitations on Charter rights is a relevant consideration and that this analysis must take place before the effects of the limitation are considered. ${ }^{247}$ However, a response to this critique would be that, in scoping the rights engaged in the dispute, the purpose and objective of actions engaging with rights on

\footnotetext{
${ }^{242}$ Dagenais, supra note 8.

${ }^{243}$ Charter, supra note 7, section $11(\mathrm{~d})$.

${ }^{244}$ Dagenais, supra note 8 . I have here paraphrased and generalised the test applied in Dagenais, per Chief Justice Lamer, set out at para 878.

${ }^{245}$ In R. v. Mentuck [2001] S.C.J. No. 73, the Supreme Court tailored the Dagenais test to address situations where Charter rights may compete with other rights or values not recognised in the Charter (in that case, broader justice concerns).

246 Dagenais supra note 8 at para 887; Iacobucci J, supra note 206 at 145.

${ }^{247}$ Big M, supra note 136; Oakes, supra note 224.
} 
both sides will be determined first as a matter of logic before the court turns its mind to the effect of the limitation on those rights. The Court's use of the Dagenais framework in freedom of religion and equality rights cases is also examined in detail in Chapter 3 with reference to the Trinity Western decision.

\section{Analysis: differences between the Oakes and Dagenais frameworks}

Justice Iacobucci explains the distinction between those cases where the court's task is to resolve a conflict of individual rights versus the task of balancing a right against a legislative objective (that may also have the effect of protecting rights, such as anti-discrimination legislation) by distinguishing between cases where the protected Charter rights of two individuals or parties are in conflict, as 'reconciliation cases' where "a court seeks to reconcile the constitutionally guaranteed rights of one individual with those of another," ${ }^{248}$ with section 1 cases where one party challenges the validity of legislation or state action on the basis of a prima facie breach of a Charter right. $^{249}$

There are therefore two substantive differences between the different assessment exercises:

1. In a 'reconciliation' case, the parties bear no onus of 'proving' a breach of a Charter right, ${ }^{250}$ (although in practice they will have to show how the actions of the opposing party limit their right); and

2. The task of demonstrating that a limitation on a right is justified under section 1 is more 'broad based' than rights reconciliation, as section 1 "implicitly authorizes the courts to balance the guaranteed rights [of individuals] against competing societal values." ${ }^{251}$ These societal values can include a much broader assessment than the scope of competing Charter rights.

Whether there is a real difference between the Oakes test analysis in freedom of religion cases and the more general 'reconciliation' analysis that a Court engages in where the rights of two individuals are at play remains to be seen. The overlap between the proportionality test in the

\footnotetext{
${ }^{248}$ Iacobucci J supra note 206 at 141.

${ }^{249} \mathrm{Ibid}$.

${ }^{250} \mathrm{Ibid}$.

${ }^{251}$ Hogg, Constitutional Law of Canada, supra note 209 at 33-10.
} 
fourth limb of Oakes and the Dagenais framework indicates that the court will engage in a 'balancing' exercise in both tests and they therefore share significant aspects in terms of assessment criteria.

These similarities might have been downplayed by scholars and jurists prior to the Supreme Court of Canada's decision in Alberta v Hutterian Brethren of Wilson Colony. ${ }^{252}$ As her Honour Chief Justice McLachlin noted in that case, the final stage of the Oakes justification analysis had not previously been relied upon to invalidate or uphold a legislative limitation on rights. ${ }^{253} \mathrm{Her}$ Honour noted that Hogg considered that the fourth limb of the Oakes test was irrelevant on the ground that it substantially mirrored the test of 'pressing and substantive objective', ${ }^{254}$ and that the real balancing task must therefore always be done at the stage of minimal impairment and, to a more limited extent, rational connection between the objective and limitation. ${ }^{255}$

Chief Justice McLachlin refuted Hogg's conclusion by drawing a distinction between purpose and effect. Her Honour reasoned that the first three stages of the Oakes test are "anchored in an assessment of the law's purpose" while only the fourth branch takes account of the effects of a rights-limiting measure on individuals and groups. Her Honour held that an assessment of the prospective (or actual) effects of a limitation will be the deciding factor for a proportionality assessment where "no alternative means are reasonably capable of satisfying the government's objective". ${ }^{256}$ The court must then determine whether the effects of limiting rights are worth the cost. Her Honour held that the Court must make a two-tiered inquiry into (a) the salutary effects of the legislative goal and (b) the deleterious effects of the limit on the Charter right. In Hutterian Brethren, her Honour held that the practical evidence before the Court indicated that the limitation on religious freedom for the Hutterites was one of cost and convenience, rather than the deprivation of a meaningful choice as to religious practice or freedom to engage in a religious practice.

\footnotetext{
${ }^{252}$ Alberta v Hutterian Brethren of Wilson Colony 2009 SCC 37, [2009] 2 S.C.R. 567 [Hutterian Brethren].

${ }^{253}$ Ibid per McLachlin CJ, at para 75.

${ }^{254} \mathrm{Ibid}$.

${ }^{255} \mathrm{Ibid}$.

${ }^{256}$ Ibid per McLachlin CJ, at para 76.
} 
Her Honour applied a two part test within the proportionality assessment, which mirrors the Dagenais framework (although she did not explicitly reference that line of authority):

The matter stands to be resolved on whether the deleterious effects of a measure on individuals or groups outweigh the public benefit that may be gained from the measure.... where the demand is that the right be fully respected without compromise, the justification of the law imposing the limit will often turn on whether the deleterious effects are out of proportion to the public good achieved by the infringing measure. ${ }^{257}$

The Supreme Court of Canada's decision in Hutterian Brethren has given new significance to the proportionality of effects element of the Oakes test and may have brought the different proportionality assessments closer in substance. In his summary of 'rights reconciliation' cases, Justice Iacobucci accepts that rights reconciliation between two Charter rights usually involves an Oakes type analysis, although he argues that the focus of that analysis will be on centred on the proportionality assessment. ${ }^{258}$ Justice Iacubucci noted that this aspect of the test has been criticized (as per the criticism of Hogg set out above) and also on the grounds that it is too subjective, and 'leaves too much interpretative room for courts to decide these Charter cases appropriately and consistently., 259

However, Justice Iacobucci defended the proportionality of effects analysis on the same grounds as Chief Justice McLachlin some years later, on the basis that it is a reality of judicial review that judges must rule on the circumstances before them, and in rights conflict cases, a framework that can encompass all guiding constitutional principles about Charter rights and reconcile these principles with the individual case at hand requires a proportionality assessment. We need, therefore, a Dagenais framework, because this 'allows courts to make case-specific determinations without sacrificing legal precedent or principle. ${ }^{260}$ In the next Chapter, I consider the Court's application of the two types of proportionality assessments in relation to two freedom of religion and equality rights challenges, and consider the degree to which they 'resolve' rights conflicts and the degree to which they favour a 'one set trumps another' approach.

${ }^{257} \mathrm{Ibid}$, per McLachlin CJ at para 78.

${ }^{258}$ Iacobucci J, supra note 206 at 157.

${ }^{259} \mathrm{Ibid}$, at 158 .

${ }^{260} \mathrm{Ibid}$, at 159. 


\section{CHAPTER 3}

\section{Balancing rights in practice - Canadian cases}

\section{Introduction}

In the cases of Ross $v$ New Brunswick School District No. $15^{261}$ and Trinity Western ${ }^{262}$ the issue of conflict of rights centred around competing interests of 'group' equality rights (Jewish students in Ross and the LGBTI community in Trinity Western) and the degree to which the right of religious freedom protected speech and actions that affected those groups. However, the nature of the rights conflict is different in both cases and the balancing mechanism that the Supreme Court of Canada applied to resolve the conflict of rights reflected this difference.

I selected Ross and Trinity Western to illustrate the Court's approach to rights reconciliation because these cases deal explicitly with engagement between two competing rights (although, in both cases, the equality law rights were expressed either in provincial human rights legislation (Ross) or the administrative decision of a Tribunal (Trinity Western). Therefore, there was no engagement with section 15 of the Charter. However, given the broad interpretation of equality 'rights' as societal and community values, this does not diminish their comparative value. In fact, it arguably increases their value as yardsticks for Australian cases where there no constitutional right to equality to apply.

Further, I have chosen these cases because they deal with key social issues that are recurrent in rights conflict debate: religious pluralism, religious conservatism and sexual orientation discrimination. These issues were also a focus on my chapter on Australian anti-discrimination and human rights law. Another reason for selection these cases was their focus on the prospective effects of discrimination and religious belief on young people and their engagement in public life

261 [1996] 1 S.C.R 825, 133 D.L.R. (4th) 1 [Ross].

262 Trinity Western University, supra note 214. 
(education) and the complex issues that have to be examined before making a finding of discrimination or an unlawful infringement on religious freedom. ${ }^{263}$

\section{The Oakes test applied: Ross}

In Ross, the Supreme Court of Canada upheld the validity of an administrative decision of the New Brunswick Human Rights Tribunal that ordered School Board to take action to prevent racist and anti-Semitic statements being made by Ross, by removing him from classroom teaching and to limit his interaction with school children. ${ }^{264}$ There were two threshold questions determined by the Supreme Court of Canada before moving to the Oakes analysis. I consider these issues first, as the Court's findings on these issues were relevant to its consideration of aspects of the Oakes test.

The first threshold question was whether the Board of Inquiry (convened by the New Brunswick Human Rights Commission) had erred in finding that the School Board of New Brunswick (School Board) had unlawfully discriminated against a Jewish complainant (Mr. Attis) and his children under section 5(1) of the New Brunswick Human Rights Act (HR Act) ${ }^{265}$ by failing to remove Mr. Ross from acting teaching duties, after repeated reports and complaints about Mr. Ross's public statements that the Board of Inquiry held to be "racist, discriminatory and bigoted statements against Jewish people." 266

The Supreme Court of Canada held that the Inquiry Board was entitled to determine that Mr. Ross's public comments about the Jewish religion were discriminatory for the purposes of section 5(1) of the HR Act. The Court noted that the respondent did not contest the findings in relation to his off-duty conduct and the anti-Semitic nature of the publications and did not lead evidence in relation to anti-Semitic incidents in the New Brunswick School District. However, he disputed the finding that there was a causative link between these two events, noting that he did

\footnotetext{
${ }^{263}$ This issue, of when and how religious freedom interacts with secular education is a live issue in Canada at present. On March 24, 2014, the Loyola appeal was heard by the Supreme Court of Canada. It is anticipated that a judgment will be rendered by the end of November 2014. The appeal dealt with the decision of the Quebec Court of Appeal (2012) to refuse to allow Loyola to teach a Catholic morality and ethics course.

${ }^{264}$ Ross, supra note 261 at para 7.

${ }^{265}$ Section 5(1) of the New Brunswick Human Rights Act, R.S.N.B., 1973, c.H-11.

${ }^{266}$ Ross, supra note 261 at para 2.
} 
not make any anti-Semitic comments in his professional capacity as a middle school teacher. ${ }^{267}$ Mr. Ross stated that there must be a difference between his professional and personal conduct and that his Charter rights to freedom of religion and freedom of expression protected comments made in the latter respect.

The Court held that, whether Mr. Ross's conduct did in fact impact on the school community must be answered on the basis of the actual environment in the school as indicated by the evidence. The Court accepted the arguments put by the Inquiry Board that strong evidence of anti-Semitic behaviour at the school and the extremely public nature of Ross's comments (including this promotion of published works that denied the holocaust and warned against an international Jewish conspiracy) $)^{268}$ supported the Inquiry Board's findings. In accepting that there was a strong 'inferred link' between the anti-Semitic statements made by Ross in his private life and anti-Semitic behaviour at the school, the Court took into account the following evidence:

(a) Repeated and continual anti-Semitic harassment at the school in the form of name calling, carving swastikas by other students into their own arms and into the desks of Jewish children, drawing swastikas on blackboards and general intimidation of Jewish students. $^{269}$

(b) Further evidence of taunting and intimidation- including "incidents of shouting and signalling of the 'Heil, Hitler' salute."270

(c) Evidence given by Mr. Attis's children that they felt uncomfortable and unwelcome when they visited the school, and the fact that they knew the school employed a teacher 'who hated Jews'.

The Court held that this evidence of discriminatory effects supported a reasonable inference that the continued employment of Mr. Ross at the school impaired the educational environment characterised by a lack of equality and tolerance, ${ }^{271}$ and this supported the finding of a link

\footnotetext{
${ }^{267}$ Ibid, at para 37.

${ }^{268}$ These works are referenced in the Inquiry Board's order, at heading (d): Web of Deceit, The Real Holocaust (The Attack on Unborn Children and Life Itself), Spectre of Power and Christianity vs. Judeo-Christianity (The Battle for Truth).

${ }^{269}$ Ross, supra note 261 at para 40.

${ }^{270} \mathrm{Ibid}$.

${ }^{271} \mathrm{Ibid}$, at para 45.
} 
between Mr. Ross's personal conduct and the school environment, sufficient to ground a finding of discrimination. ${ }^{272}$

La Forest $\mathrm{J}$ noted that there were general concerns investigating the private conduct of a teacher as relevant to their professional conduct and stated that he did not advocate "an approach that subjects the entire lives of teachers to inordinate scrutiny on the basis of more onerous moral standards of behaviour." 273 However, the strong evidence of discriminatory conduct at the school and the highly public nature of Ross's anti-Semitic comments had "impaired the educational environment generally in creating a "poisoned" environment characterised by a lack of equality and tolerance" 274 and, in these circumstances, it was appropriate to evaluate the effects of his private statements and to find them sufficient to support a finding of discrimination in relation to the 'poisoned' school environment.

\section{Scoping the rights at play: a breach of freedom of religion}

The second question was whether Inquiry Board's order was constitutionally valid. Mr. Ross brought a Charter challenge to the validity of the order on the basis that it was an unlawful breach of his right to freedom of expression (section 2(b)) and his right to freedom of religion (section 2(a)). ${ }^{275}$ Every appellant (bar the Canadian Jewish Congress), conceded that there was an infringement of the respondent's rights to religious freedom and freedom of expression, and La Forest J was quick to accept that the substance of the order did infringe on Mr. Ross's religious beliefs. ${ }^{276}$ La Forest J agreed with the respondent's view that the role of the Court was not to scrutinise the morality or validity of a religious belief. Rather, "it was sufficient to trigger constitutional scrutiny if the effect of the impugned act or provision interfered with an individual's religious activities or convictions. ${ }^{\text {277 }}$ La Forest J relied on the expansive definition

\footnotetext{
${ }^{272} \mathrm{Ibid}$, at para 45.

273 Ibid, at para 45.

274 Ibid, at para 49.

${ }^{275}$ For the purposes of this discussion, the freedom of expression challenge is not relevant. However, it is clear that there is often, if not always, a complementary freedom of expression argument to be made in freedom of religious expression cases.

${ }^{276}$ Ross, supra note 261 at paras $62-63$ in regards to freedom of expression and at paras $72-74$ in regards to freedom of religion.

${ }^{277} \mathrm{Ibid}$, at para 71 .
} 
of religious belief provided by Dickson CJ in Big $M$, highlighting the subjective and personal nature of religious belief. ${ }^{278}$

La Forest J reaffirmed the Supreme Court's traditional approach to Charter analysis, namely that it is appropriate to give a broad and purposive reading to the right and to resist invitations to define internal limitations to Charter rights. ${ }^{279}$ His Honour quoted his judgment for the majority in B.(R). v Children's Aid Society of Metropolitan Toronto ${ }^{280}$ where he stated that any 'ambiguity or hesitation' in terms of the scope of section 2(a) should be determined in favour of the right, ${ }^{281}$ while section 1 remained the "flexible tool with which to balance competing rights." 282 On this basis, the Court held that the order infringed freedom of expression and freedom of religion and then turned to the secondary issue of whether those limitations are reasonable under section 1.

In his consideration of section 1 of the Charter, La Forest $\mathrm{J}$ made some preliminary points about the Oakes analysis and the preferred approach to rights balancing in equality rights cases. First, his Honour noted that proper approach is to avoid applying a 'formalistic test', but rather that the test should be applied flexibly so as to achieve a proper balance between individual rights and community needs, ${ }^{283}$ and this requires that the court undertake a careful contextual analysis, taking into account relevant social values and factual context. ${ }^{284}$ In terms of the contextual analysis in Ross, La Forest $\mathrm{J}$ accepted three categories of social context proposed by the New Brunswick Human Rights Commission: the educational context, employment context and antiSemitism context. ${ }^{285}$

\footnotetext{
${ }^{278} \mathrm{Ibid}$, at para 72, quoting Dickson CJ in R.v. Big M supra note 136 at 336: "The essence of the concept of freedom of religion is the right to entertain such religious beliefs as a person chooses, the right to declare religious beliefs openly and without fear of hindrance or reprisal, and the right to manifest religious belief by worship and practice or by teaching and dissemination."

${ }^{279} \mathrm{Ibid}$, supra note 261 at para 72. La Forest J quoted the majority judgment in B.(R). v Children's Aid Society of Metropolitan Toronto [1985] 1 S.C.R. 315 [B.(R).].

${ }^{280} \mathrm{Ibid}$, B. (R).

${ }^{281}$ Ibid, Ross, per La Forest J at $383-384$.

${ }^{282} \mathrm{Ibid}$, per La Forest J at $383-384$ (emphasis added).

${ }^{283}$ Ross, supra note 261 at 78.

${ }^{284}$ Ibid; see also Rocket v. Royal College of Dental Surgeons of Ontario, [1990] 2 S.C.R. 232 per McLachlin J (as she then was) at paras $246-247$.

${ }^{285} \mathrm{Ibid}$, Ross, supra note 261 at paras $79-81$.
} 
In considering the educational context, the Court accepted the Commissions submission that every individual has a right to be educated in a school system that is free from bias, prejudice and intolerance and that any manifestation of discrimination on the basis of gender, race, ethnicity, culture or religion is not acceptable. ${ }^{286}$ In addition, the Court noted that an "additional driving factor" was the nature of the educational services in question, noting that Mr. Ross worked in an environment dedicated to the education of young children, and that "[w]hile the importance of education of all ages is acknowledged, of principal importance is the education of the young,"287 and this particular context must be invoked when balancing the an individual's freedom to make discriminatory statements against the right of children to be educated in a tolerant and impartial school system, "a right that is underscored by section 5(1) of the Act and entrenched in section 15 of the Charter." 288

The Court held that the second relevant social context for this dispute was the duty of the State, as an employer, to ensure that the "fulfillment of public functions is undertaken in a manner that does not undermine public trust and confidence." ${ }^{289}$ The Court expressed this context in the language of balancing rights: as a conflict between the 'interests' of School District No. 15 to provide a non-discriminatory school system, and Mr. Ross's personal right to manifest his religious beliefs and express religious views. ${ }^{290}$

Finally, La Forest J accepted the Human Rights Commission's submission on the significance of anti-Semitism as a context for the conflict of rights in this matter:

After Auschwitz, it is simply not feasible to consider the constitutional values of freedom of expression and freedom of religion where those are proclaimed to shield anti-Semitic conduct, without contemplating the centrality of that ideology to the scourge of death and destruction which swept across Europe during the era of the Third Reich. ${ }^{291}$

\footnotetext{
${ }^{286} \mathrm{Ibid}$, at para 81.

${ }^{287} \mathrm{Ibid}$, at para 82, with reference to the Supreme Court of the United States decision in Brown v Board of Education of Topeka, 347 U.S. 483 at p. 483.

288 Ibid, Ross at para 83.

${ }^{289} \mathrm{Ibid}$ at para 84.

${ }^{290} \mathrm{Ibid}$, at para 85.

${ }^{291} \mathrm{Ibid}$, at para 86.
} 
In accepting this submission, the Court referred to the warning of Dickson CJ in Edward Books that Courts must be cautious to prevent the Charter becoming "an instrument of better situated individuals to roll back legislation which has as its object the improvement of the condition of less advantaged persons." ${ }^{292}$ The Court noted that the order of the Inquiry Board was made to remedy discrimination that targeted Jews, an historically disadvantaged group that had suffered discrimination and persecution "on the largest scale" ${ }^{293}$ La Forest J noted that the decisions of human rights commissions and tribunals have played a leading role in defining and scoping equality rights, and the Court should "proceed under section 1 with recognition of the sensitivity of human rights tribunals in this area". 294

His Honour also applied two of the general principles relating to competing rights before moving to the different limbs of the Oakes test: (a) that greater deference should be given to laws that are concerned with competing rights between two different sectors of society (in this case, people at risk of discrimination versus people affirming their religious freedom) ${ }^{295}$ and (b) that the nature of the rights at play must be considered, and in this case, the form of religious expression lies further from the core value of freedom of expression, and where this is the case, a lower 'standard of justification under section 1' has been applied." ${ }^{296}$

\section{The Oakes test applied}

\section{(a) Pressing and substantial objective}

La Forest J identified the pressing and substantial objective of the order to concern 'remedying discrimination found to have poisoned the educational environment in the School Board. ${ }^{297}$ His Honour referenced Dickson CJ's finding in Taylor that the objective of promoting equal opportunity in Canadian society was pressing and substantial, particularly when measured against the harms caused by messages of hatred, including psychological distress and the pressure to renounce minority cultures. ${ }^{298}$ Applying these principles and considering Canada's international obligations and the entrenchment of equality rights in the Charter, La Forest $\mathrm{J}$ found the

\footnotetext{
${ }^{292}$ Ibid, at para 86, citing $R$ v. Edwards Books and Art Ltd., [1986] 2 S.C.R. 713 at p. 779.

${ }^{293}$ Ibid, Ross at para 86.

294 Ibid at para 87.

${ }^{295}$ RJR - MacDonald Inc. v Canada (Attorney-General), [1995] 3 S.C.R. 199, per McLachlin J at para 331.

${ }^{296}$ Ross, supra note 261 at para 88.

${ }^{297}$ Ibid, at para 96.

${ }^{298} \mathrm{Ibid}$, at para 97 (citations omitted).
} 
objective of the order to be the elimination of discrimination and the promotion of equality and to be 'pressing and substantial'. 299

\section{(b) Rational connection}

The first three requirements of the Inquiry Board's order were found to be rationally connected to the objective of eliminating discrimination, on the basis that they focus on providing relief and avoiding 'punitive effects'. ${ }^{300}$ Key to the finding of rational connection in relation to these orders were that they sought to remove the respondent from his teaching position immediately, on the basis that his public anti-Semitic statements had contributed to the 'poisoned environment' in the school system, and therefore his conduct failed to meet the expected standard of public teachers: that they ensure that their conduct transmit a "message of equality to the community at large". 301 La Forest $\mathrm{J}$ held that clause 2(d) of the order, which required the School Board to terminate Ross's employment immediately if he continued to 'publish or write... anything that mentions a Jewish or Zionist conspiracy, or attacks followers of the Jewish religion' or if he published or sold any of a list of published works that were anti-Semitic. ${ }^{302}$ This part of the order was found to be not rationally connected to the remedial anti-discrimination framework of the HR Act and was also not minimally impairing. On this basis, clause (d) was struck from the order on the basis that it failed the Oakes test.

\section{(c) Minimal impairment}

In considering the elements of minimal impairment, La Forest $\mathrm{J}$ noted that the impairment of the rights engaged must be minimal to the extent that it impairs the right no more than 'is necessary', however the process of matching the legislative limitations to the need of the objective is not an exact science, and therefore "if the law falls within a range of reasonable alternatives, the courts will not find it overbroad" merely because there might be an 'optimal' solution not identified. ${ }^{303}$ In holding that the order to remove Ross from active teaching duties was minimally impairing, La Forest $\mathrm{J}$ noted that the Inquiry Board had carefully considered the alternatives available to remedy discrimination, and found that the removal of the respondent from the classroom was the

\footnotetext{
299 Ibid, at para 98.

$300 \mathrm{Ibid}$, at para 100 .

301 Ibid, at para 101.

$302 \mathrm{Ibid}$, at para 102 .

${ }^{303} \mathrm{Ibid}$, at para 103, citing RJR-McDonald, supra note 295 per McLachlin J at para 342.
} 
only real option to cease the discrimination. ${ }^{304}$ This was because Mr. Ross would not have consented to an apology and cessation guarantee, as demonstrated by his previous refusal to cease publication or public statements about Jews and Christianity. The Board had also rejected the option of excluding Jewish children from his classes, on the basis that this would be directly at odds with the statutory objective of promoting inclusion and diminishing racial and religious disadvantage. On balance, La Forest $\mathrm{J}$ accepted that the Board had considered a range of options and that clauses (a) - (c) of the order were 'carefully tailored' to accomplish their objective: 'to remedy the discriminatory situation in School District 15 created through the writings and publications of Malcolm Ross.”305

La Forest $\mathrm{J}$ noted that his decision to sever clause (d) from the order on the basis of an unlawful infringement on Charter rights, meant that there was no permanent ban on Ross's public promotion of his religious beliefs. In so finding, the Court placed a limit on the 'poisoned environment' principle, holding that the evidence did not support the conclusion that the residual 'poisoned effect' of Ross's presence in the school in a non-teaching role would last indefinitely and would be lessened if Ross was not in a teaching position of 'influence and trust'. 306

\section{(d) Proportionality between effects of order and limits on rights}

The consideration of the deleterious effects on the right of religious freedom is rather perfunctory, as is common in rights balancing jurisprudence prior to Hutterian Brethren. ${ }^{307} \mathrm{La}$ Forest $\mathrm{J}$ notes that the effects of the order in relation to a removal from active teaching only limit the respondent's right to freedom of religion only to the extent required to achieve their purpose. ${ }^{308}$ His Honour considered that the remedial aspects of the order, including the statement that Ross was not prevented from holding a non-teaching position should one become available and that he was to be offered commensurate salary and benefits within such a position as a

\footnotetext{
${ }^{304}$ Ibid, Ross at para 104.

305 Ibid, at paras $105-106$.

306 Ibid, at para 107.

${ }^{307}$ Hutterian Brethren, supra note 252.

${ }^{308}$ Ross, supra note 261 at para 108.
} 
teaching position, were a reasonable balance to the limits on his religious freedom.

\section{Commentary on the application of the Oakes test in Ross}

In Ross, the Supreme Court of Canada attempted to strike a difficult balance between the fundamental religious freedom rights of an individual versus the community 'values' and 'rights' of non-discrimination and promotion of tolerance and respect for minority groups. However, the rights engaged in Ross can also be presented as a conflict between the rights of two individual players: namely the rights of Mr. Attis and his family and the rights of Malcolm Ross.

By engaging in a 'balancing' exercise under section 1 of the Charter, the Court was able to give a broad reading to the right of freedom of religion and a broad reading to equality rights expressed as a significant value within three societal contexts: public education, public employment of teachers and the history of western anti-Semitism. The Court made fleeting reference to constitutionally entrenched 'equality rights' as embodied in section 15 of the Charter, but framed the rights conflict as 'rights' versus 'broad social values', preferring the approach to equality guarantees taken by the Dickson Court in Keegstra and Taylor.

In her dissent in Trinity Western (discussed below), L'Heureux-Dubé J commented that the difference between Ross and that case appeared to be the hard 'evidence' of discrimination against an historically recognised disadvantaged group. While the evidence of discrimination was not directly referenced in the Court's findings under the different elements of the Oakes test, La Forest J refers to the 'poisoned atmosphere' of the school community as a relevant factor in his reasoning about pressing and substantial objective, minimal impairment and rational connection. The 'poisoned atmosphere' of the general school community was a finding only arrived at after the Court was satisfied that there was an inferred link between the publication of Ross's antiSemitic views and the discriminatory acts that occurred in the school community while he was teaching there.

What does this tell us? First, that the Supreme Court of Canada was willing to go beyond the traditional expansive reading of freedom of religion (and freedom of expression) where the equality rights at issue were tangibly identified and concretely limited. Second, that, in practice, this will mean presenting evidence of discrimination against a targeted group. It was central in 
Ross that the defendant was well-known for holding anti-Semitic and racist views and that he had held these views for a long time while he was a middle school teacher. In fact, Ross had taught at the school since 1975, and the decision of the Inquiry Board of the New Brunswick Human Rights Commission was not issued until 1988. The Court also emphasised the strong arguments made by the New Brunswick Human Rights Commission in relation to anti-Semitism in Canadian society and the importance of a non-discriminatory educational experience in terms of the section 1 analysis (rational means of achieving the legislative objective). However, the Court seemed convinced by arguments of overt discriminatory conduct and acts of violence by school children in terms of a balance of equality rights as against freedom of religion.

Curiously, the Court applied the Oakes analysis to both Charter rights' infringements, rather than engaging in a separate balancing exercise for each right. While this might seem to be appropriate given the classification of Mr. Ross's anti-Semitic statements as speech verging on hate speech (and therefore close to the facts and context considered by the Court in Keegstra and Taylor), the rights conflict at issue in Ross were not the same as in the 'hate speech cases'. Ross was not found to have discriminated against Mr. Attis and his family, nor was he held to be in breach of the hate speech prohibitions in the Human Rights Act. Rather, the School Board's action in refusing to stand him down from active teaching was held to be discriminatory by the Inquiry Board, and it was this threshold of discrimination in educational services that was considered by the Supreme Court of Canada, rather than the validity of 'hate speech provisions'.

In later cases, the Court would come to prefer an openly subjective test for religious belief, and to favour an 'expansive reading' of what constitutes religious expression, resisting the opportunity to internally limit the freedom of religion right in section 2(a). ${ }^{309}$ I contend that the Court in Ross conflated legal principles relevant to freedom of expression with its findings as to freedom of religion and this coloured the section 1 analysis. In my view, this merging of the rights issue in the section 1 analysis was possible because of the strong reliance on the factual evidence of discriminatory conduct in the school environment. The pro-equality rights emphasis in La Forest

\footnotetext{
${ }^{309}$ For example, the Supreme Court of Canada's findings as to the nature of a personally held religious belief in Amselem (supra note 181) and the decision of the majority in $B$. (R.) to refrain from formulating internal limits to the scope of freedom of religion. Although see the dissenting judgment of Iacubucci and Major JJ, which critiqued the role of the section 1 analysis as the sole mechanism for rights balancing: $B$. $(R)$, supra note 279 at paras $117-118$.
} 
J's judgment is clear from his finding about the discrimination order, and this appears to constitute almost a de facto proportionality assessment of the Charter rights engaged, before the Oakes analysis is carried out.

The Oakes analysis in Ross stresses (a) the nature of the order's objective within a broader context of tolerance and non-discrimination in the public sphere and (b) minimal impairment. This emphasis in the balancing exercise enabled La Forest $\mathrm{J}$ to take a flexible view of the rights engaged, and to broaden the 'objective' sought by the order to contemplate international obligations in relation to equality rights and a promotion of tolerance within public education. What is also clear from the balance of reasoning in the Oakes analysis is that to the point that there is an identified conflict of rights (classified as 'individual freedoms' and 'societal values') this is resolved in favour of equality rights.

Critics of this position would note that the severance of clause 2(d) of the Inquiry Board's order had the effect of preferring the religious freedom right in circumstances that went beyond Mr. Ross's professional role. The Supreme Court of Canada held that the Inquiry Board could not prevent Mr. Ross from continuing to publish his religious views after he had served the 18 month suspension period and after he had been stood down from active teaching duties. In effect, the Court asked Mr. Ross and the Inquiry Board to draw a line between private religious conduct (protected) and public teaching (not protected).

While the Court was careful to consider the impact on freedom of religion and expression for Mr. Ross, ultimately it determined that the discriminatory effects of his private conduct were felt in a public education context and that the actions taken by the Inquiry Board in relation to suspending him from teaching duties were a reasonable limitation on his freedom of religion and freedom of expression rights. 


\section{The Dagenais framework for reconciling individual rights 'conflict': Trinity Western}

In Trinity Western, a majority of the Supreme Court of Canada ${ }^{310}$ considered a similar 'conflict of rights' issue as in Ross, although with different claims about the degree of connection and (potential) conflict between the right of religious freedom and equality rights. As Margaret Ogilvie noted in her critique of the Court's judgment in Trinity Western, ${ }^{311}$ Ross and Trinity Western are not perfect analogies. Whereas Ross concerned the conduct of a teacher in a public school, while Trinity Western involved a standard set by a private educational institution, run and funded by the Evangelical Free Church of Canada. As a private institution, Trinity Western is not subject to the Charter and it is questionable whether it could have mounted a Charter challenge in relation to an infringement of section 2(a). ${ }^{312}$ Further, the facts in Trinity Western engaged the operation of a religious exemption provision in the previous section 19 of the British Columbia Human Rights Act (BCHR Act), ${ }^{313}$ which relevantly provides that a religious institution is not acting in breach of the BCHR Act where it prefers adherents of its own religion. ${ }^{314}$

There are strong similarities between the position taken by Trinity Western and the position taken by Christian Youth Camps in the Cobaw litigation, discussed in Chapter 1, and some of the discussion in relation to the Court's approach to the private institution element in Trinity Western is relevant to my analysis of the Victorian Court's approach of the rights engaged in Cobaw. ${ }^{315}$ Trinity Western conducted a teaching program without full accreditation, with final-year assessment and monitoring carried out by Simon Fraser University (a publicly funded university). Trinity Western applied to the British Columbia College of Teachers (BCCT) for full

\footnotetext{
${ }^{310}$ For the majority: McLachlin CJ and Gonthier, Iacobucci, Major, Bastarache, Binnie, Arbour and LeBell JJ, with L'Heureux-Dubé J in dissent.

${ }^{311}$ M.H. Ogilvie, "After the Charter: Religious Free Expression and Other Legal Fictions in Canada" 20022 Oxford U. Comm. L.J $219-235$ at 224 ["After the Charter"].

312 In her dissenting judgment, L'Heureux-Dubé notes that “TWU's claim [in regards to a breach of section 2(a)] must confront the obstacle that this Court has not yet decided whether a religiously based corporation may initiate a s2 (a) claim or whether in challenging the BCCT's decision TWU qualifies for standing as of right", Trinity Western supra note 214 at para 99, see also: Canadian Egg Marketing Agency v. Richardson, [1998] 3 S.C.R. 157.

${ }^{313}$ At time of judgment, Human Rights Act, S.B.C. 1984, c. 22, now the Human Rights Code, R.S.B.C (1996), c. 120.

${ }^{314}$ Section 41(1) of the Human Rights Code provides: If a charitable, philanthropic, educational, fraternal, religious or social organization or corporation that is not operated for profit has as a primary purpose the promotion of the interests and welfare of an identifiable group or class of persons characterized by a physical or mental disability or by a common race, religion, age, sex, marital status, political belief, colour, ancestry or place of origin, that organization or corporation must not be considered to be contravening this Code because it is granting a preference to members of the identifiable group or class of persons.

${ }^{315}$ See discussion above, Chapter 1, heading II at 36.
} 
accreditation, with one of the reasons given for accreditation being the desire of Trinity Western to have the full teaching program reflect the institution's 'Christian worldview'. BCCT refused to grant the application for accreditation, on the basis that it was contrary 'to the public interest' for it to approve a teaching program offered by an institution which followed discriminatory practices. The basis of the BCCT decision was a 'community standards' (Community Standards) document that all staff and students were required to sign. The Community Standards set out a list of 'biblically condemned activities' which included 'sexual sins including... homosexual behaviour.' ${ }^{316}$ The BCCT held that the Community Standards were a discriminatory practice and created a 'real risk' that Trinity Western teaching graduates would not provide a discrimination free environment for all public school students as graduate teachers. ${ }^{317}$

\section{Conflict of rights issue - the Dagenais framework applied}

The Supreme Court characterised the key question as being how to reconcile the religious freedoms of the individual teaching students attending Trinity Western (or wishing to attend) with the concerns of BCCT on behalf of students in the public education system about equality, tolerance and a promotion of a non-discriminatory education environment:

In our opinion, this is a case where any potential conflict should be resolved through the proper delineation of the rights and values involved. In essence, properly defining the scope of the rights avoids a conflict in this case. ${ }^{318}$

In this sentence, the Court neatly resolved the rights-conflict issue, and flags that it will apply the Dagenais framework for rights reconciliation rather than a section 1 analysis. The Court notes that neither the right of religious freedom, nor the right to freedom from discrimination, are absolute rights, and applies the Dagenais principle that there is no hierarchy of Charter rights and that the Charter must be construed holistically. ${ }^{319}$ The majority then applies these principles to the facts in Trinity Western and criticises the decision of the BCCT for failing to properly balance (and thus reconcile) equality rights of public students with the religious freedom rights of

\footnotetext{
316 Trinity Western, supra note 214 at para 4.

${ }^{317}$ Ibid, at para 18.

318 Ibid, at para 29.

${ }^{319} \mathrm{Ibid}$, at paras $29-31$ (citations omitted).
} 
students attending Trinity Western University, holding that the BCCT had to demonstrate that there was a rights conflict 'in reality', ${ }^{320}$ when in fact there was no conflict to resolve.

\section{Scoping the right to religious freedom}

The majority held that BCCT failed to take into account the relevant scope of freedom of religion as a protected right of the members of Trinity Western, citing the expansive definition of freedom of religion given in Big M. ${ }^{321}$ The majority noted that the inclusion of religious exception provisions in the Human Rights Act and the affiliation of Trinity Western with a particular Christian Church, should also have been taken into account in scoping freedom of religion. ${ }^{322}$ The majority held that the application of the exemption provision to Trinity Western as a private educational institution did not mean that the individuals graduating from this institution were " $d e$ facto considered unworthy of fully participating in public activities", ${ }^{323}$ and that a failure to allow those students who chose to attend Trinity Western because of its Christian ethos to graduate as teachers was a significant limit on their religious freedom. ${ }^{324}$

\section{Scoping equality rights}

The Supreme Court of Canada unanimously dismissed Trinity Western's claim that BCCT had no jurisdiction to consider whether Trinity's Community Standards were discriminatory. ${ }^{325}$ The Court made this finding on the basis that the statutory requirement to establish standards for public education ${ }^{326}$ included a 'public interest' test that went beyond the requirement to ensure the competency and training of teachers. The Court cited its statement in Ross that teachers are a "medium for the transmission of values... [and that] the pluralistic nature of society and the extent of diversity in Canada are important elements that must be understood by future teachers because they are the fabric of the society within which teachers operate."327

Given this context, the majority held that it was appropriate for BCCT to consider whether the

\footnotetext{
${ }^{320} \mathrm{Ibid}$, at para 32 .

${ }^{321} \mathrm{Ibid}$, at paras 28 - 29. The majority cited Dickson CJ's definition of religious freedom in Big M, supra note 136 at $336-337$.

322 Ibid at para 32.

${ }^{323} \mathrm{Ibid}$, at para 35.

${ }^{324} \mathrm{Ibid}$, at para 35.

325 This was the point of concurrence between the majority and minority.

${ }^{326}$ Teaching Profession Act, R.S.B.C. c. 1996, c.449, section 4.

327 Trinity Western, supra note 214 at para 13.
} 
Community Standards were discriminatory in nature and that equality rights were relevant to its accreditation decision. The majority refers to the fundamental significance of equality rights to Canadian society, ${ }^{328}$ and notes that the equality guarantees in British Columbia human rights legislation and the Charter include protection against discrimination based on sexual orientation. The majority cites its decision in Egan v Canada as an explicit recognition of gays and lesbians as "an identifiable minority who have suffered and continue to suffer serious social, political and economic disadvantage." ${ }^{329}$

The Court is careful to scope equality rights as applying more broadly than the Charter, as the Charter does not apply to Trinity Western, and therefore a close examination of equality rights as set out in section 15 would be redundant. In this way, the Court's scoping of equality rights mirrors its approach in Ross: taking equality rights to be community values that have a particular significance when applied in the context of public education.

In relation to the Community Standards document, the majority notes the fact that Trinity Western is a private institution that students could choose to attend and, if they did, would be aware of its Christian ethos and position on issues such as homosexual behaviour. The majority noted that, "while homosexuals may be discouraged from attending TWU, a private institution based on particular religious beliefs, they will not be prevented from becoming teachers. In addition, there is nothing in the TWU Community Standards that indicates that graduates of TWU will not treat homosexuals fairly and respectfully." ${ }^{330}$

This statement seems isolated from the majority's reasoning in relation to the breach of equality rights, which is really targeted at prospective impacts on public school children by Trinity Western graduate teachers rather than the potential discriminatory impact on students at Trinity Western. Indeed, the Court notes that the actions of Trinity Western in requiring all staff and students to sign the Community Standards are most likely lawful discrimination (in the event of a

\footnotetext{
${ }^{328} \mathrm{Ibid}$, at para 26. The majority quotes Cory J's discussion of section 15 of the Charter in Vriend, supra note 170 at para 175: "The rights enshrined in section 15(1) of the Charter are fundamental to Canada. They reflect the fondest dreams, the highest hopes and finest aspirations of Canadian society."

${ }^{329} \mathrm{Ibid}$, at para 27, quoting Egan v Canada, [1995] 2 S.C.R. 513 per Cory J at para 175 and per L'Heureux-Dubé at para 89.

${ }^{330} \mathrm{Ibid}$, at para 35 .
} 
claim) given the application of the religious exception provision in the BCHR Act. Conflating the treatment of Trinity Western students with prospective discrimination done by Trinity Western graduates does not assist the Court in reaching a balance of rights, nor does it further the Court's analysis of the societal value of non-discrimination and equality. The Court notes that rights of those affected by the conduct of Trinity Western must be construed as rights enjoyed by individuals: therefore the Court bases its reconciliation assessment on the lack of concrete evidence of discrimination against children in the public school system.

\section{Reconciling rights in context: line between belief and conduct}

The Court held that the proper place to draw the line between a valid exercise of freedom of religion and a potentially unlawful conflict of rights is between belief and conduct: applying to 'core/periphery' distinction to hold that the freedom to have religious beliefs is broader than the freedom to act on them. ${ }^{331}$ The Court held that, absent any concrete evidence that "training teachers at TWU fosters discrimination in the public schools of B.C, the freedom of individuals to adhere to certain religious beliefs while at TWU should be respected." ${ }^{332}$ The Court reasoned that, for BCCT to have properly denied accreditation on a discrimination basis, it should have presented specific evidence of discriminatory conduct at odds with public education values. The majority referenced Ross as a case where the balance of rights issue was differently resolved, due to proven discriminatory conduct (acting on religious belief) that was subject to disciplinary proceedings and subsequently held to poison a total school environment. ${ }^{333}$ The majority held that, in the absence of similar evidence, the BCCT was not entitled to preference equality rights of school children over the religious freedom rights of Trinity Western graduates.

This finding in relation to the lack of discriminatory conduct is relevant to the general reconciliation principles that rights cannot be weighed in a vacuum, ${ }^{334}$ and that rights conflict must be considered within its constitutional and societal context. ${ }^{335}$ The social and educational context is vital for the majority's finding in Trinity Western. The majority distinguishes Ross on this basis (the lack of discriminatory behaviour in public schools) and holds that there is no real

331 Ibid.

${ }^{332}$ Ibid, at para 36.

${ }^{333} \mathrm{Ibid}$, at para 37 (citations omitted).

334 Same Sex Marriage, supra note 217.

${ }^{335}$ Iacobucci J, supra note 206 at 155. 
engagement with equality rights on this basis. The majority does not explicitly note that, in Ross, there was no attempt to scope the rights at issue before embarking on a section 1 analysis: that is, there is no explicit distinction made on the basis of the reconciliation/balancing approach, rather the distinction made was on the basis of the substantive facts at issue.

\section{Proportionality assessment - balancing effects}

The Court does not identify its reasoning as a proportionality assessment, primarily because it held that there was no rights conflict to resolve. However, in later comment on the case, Iacobucci J classes Trinity Western within a line of cases that apply an Oakes-type proportionality assessment of the relative deleterious effects of the limitation versus the objective sought by the limitation. ${ }^{336}$ Iacobucci J considers that the proportionality assessment in rights reconciliation "provides an analytically coherent framework to guide judicial discretion" 337 and allows Courts to make context-sensitive findings about the scope of rights, without sacrificing legal precedent or principles. ${ }^{338}$ In Trinity Western, the heart of the proportionality assessment was the lack of demonstrated discrimination in a public school setting that could be linked to the Community Standards.

\section{Dissenting judgment: the Dagenais approach critiqued}

In her dissent, L'Heureux-Dubé J rejects the approach of the majority in preferring a flexible, context-specific approach to rights reconciliation. Her Honour preferred a two-step test for assessing the BCCT decision, the first applying administrative law principles in determining 'non-Charter issues' and the second to assessing Charter claims applying the section 1 approach taken in Ross. ${ }^{339}$ L'Heureux-Dubé J stated that "the more sophisticated and structured analysis of section 1 is the proper framework within which to review Charter values." 340 In relation to a section 1 analysis, her Honour carries out a section 1 analysis in relation to the section 15

\footnotetext{
${ }^{336}$ Iacobucci J, supra note 206 at 157.

337 Ibid, at 158 .

${ }^{338} \mathrm{Ibid}$, at $158-159$.

${ }^{339}$ Trinity Western, supra note 214 at para 66.

${ }^{340}$ Ibid.
} 
equality rights claim brought by Donna Lindquist (a student at Trinity Western University) and finds that the decision to refuse accreditation is a reasonable limitation of her equality rights.

L'Heureux-Dubé J disposes of the section 2(a) by Trinity Western on the grounds of standing, but finds that, even if it could bring such a claim, it is without merit. Her Honour reaches this conclusion by finding that certification of Christian colleges and universities (and their statutory requirements) do not limit the religious freedom rights of these institutions, but rather it accommodates it: "it permits the existence of schools such as the respondent which have a religious orientation. It is a flexible piece of legislation which seeks to ensure one thing - that all children receive an adequate education." 341

L'Heureux-Dubé J addresses the scope of equality rights issue in the context of administrative law and the correct standard of review to apply to BCCT, and to that extent does not engage with the discrimination issue in the same legal context as the majority. However, for this discussion, her Honour's summary of the issues is relevant. Her Honour held that the risk of discriminatory and homophobic conduct by teachers in public schools was a real and pressing concern and that deference should be paid to BCCT in its determination in this regard. ${ }^{342}$ Her Honour summarised evidence presented to the Court by the British Columbia Human Rights Commission that gay and lesbian youth feel like outsiders at school, that a high percentage have dangerously low selfesteem and that they suffer disproportionate rates of verbal bullying and physical assault compared to heterosexual students. ${ }^{343}$ Her Honour also considered evidence that 46 percent of gay and lesbian youth in British Columbia (in 1999) had attempted suicide at least once, and that the average age of the first suicide attempt was 13 years. ${ }^{344}$ Her Honour concluded that, in this context, the decision of BCCT to refuse to accredit Trinity Western without the requirement of final year attendance at a public university was a "reasonably proactive measure designed to prevent any potential problems" of discrimination, ${ }^{345}$ and that it was within its jurisdiction to take this action. ${ }^{346}$

\footnotetext{
${ }^{341}$ Ibid, at para 99.

${ }^{342} \mathrm{Ibid}$, at para 80 (citations omitted).

${ }^{343}$ Ibid, at para 84.

${ }^{344} \mathrm{Ibid}$, at para 85.

$345 \mathrm{Ibid}$, at para 86.

${ }^{346} \mathrm{Ibid}$, at para 86.
} 
In terms of the majority's request for 'hard evidence' of discrimination before identifying a conflict of rights, L'Heureux-Dubé J comments that this takes a narrow, scholastic view of the school environment that is not consistent with the Court's findings in Ross. Her Honour notes that, in Ross, the court held that the public school environment must be broadly construed as one "where all are treated equally and all are encouraged to fully participate" 347 and, in the case of homophobia, this requires active promotion of a safe and non-discriminatory environment, as the discrimination experience of this group has, to date, been "that of the closet, an isolated refuge of invisibility often enveloped in fear." 348 Her Honour considered that the majority had taken an unnecessarily technical approach to the requirement of proof for discrimination in practice, and could, applying Ross, have used evidence of systemic discrimination in the public school system against homosexual children and young people as evidence sufficient to render BCCT decision reasonable.

L'Heureux-Dubé J's dissent embraces the difficult reality of equality rights guarantees and discrimination cases: discrimination is rarely characterised by one decisive action with assessable consequences. The effect of homophobia on young people and children is increasingly documented, although this is a recent phenomenon. However, quantitative reports on youth suicide, self-harm and mental illness as a result of homophobia also indicate that most discrimination is cumulative over time, and involves the restatement of negative stereotyping, emphasising heterosexuality as the norm and homosexuality as the abnormal. While, in some cases the complainant will be able to point to a specific action or rule that caused them hurt or injury, in many cases this will not be the case.

\section{Analysis: the approaches in Ross and Trinity Western and the impact on freedom of religion and equality rights}

It seems clear that, in terms of outcome, the difference between Ross and Trinity Western is the presence of a proven discrimination. As her Honour L'Heureux-Dubé stated in her dissent in Trinity, the majority of the Court wanted compelling evidence of discriminatory attitudes in

${ }^{347}$ Ibid, at para 89.

${ }^{348} \mathrm{Ibid}$, at para 89. 
current Trinity Western graduates before they would accept evidence of a breach of equality rights, and a consequent need to resolve a conflict of rights. Similarly, in Reference Same-Sex Marriage, the Court referred to its decision in Trinity as authority for the proposition that conflict of rights issues need only be considered when a substantive conflict has been identified. In practice, it seems that what the Court is really saying is that a conflict of freedom of religion rights with equality rights will be demonstrated when there has already been significant discrimination engaged in and detriment suffered as a result.

I consider that the clear delineation of rights and proportionality principles in Ross enabled the Court to apply clear limits to the right of religious freedom and to temper those limitations against the breadth of the right where appropriate. Further, the rights limitation approach in Ross enabled the Court to give an expansive definition of freedom of religion, and to then limit that right only in accordance with the Oakes test.

One criticism of the Court's approach in Trinity Western is that it readily accepts the principle that both equality rights and freedom of religion can be reasonably limited and appears to accept the fact that this 'limitation' process could take place when scoping the rights engaged in a conflict, rather than at the section 1 analysis stage. This could have consequences for the freedom of religion right, as it seems to go against the general principle, also applied in rights conflict cases, that the right is expansive and even controversial or minority religious views should be given prima facie protection as valid religious expression. ${ }^{349}$

Even strong critiques of Trinity Western on religious freedom grounds have been cautious about inferring that the Supreme Court of Canada preferred a new approach of internal limitations on freedom of religion. ${ }^{350}$ This may be answered by the fact that the Court did not suggest any internal limitations on the freedom of religion right, but rather found that there was no practical conflict between the rights, and made this finding by giving effect to a broad reading of both equality values and freedom of religion, but finding that there was no practical conflict (discriminatory conduct) to ground a comparative analyses of the rights in context. It would be

\footnotetext{
${ }^{349}$ Ross, supra note 261; Keegstra, supra note 187; Whatcott, supra note 241, Taylor, supra note 171.

${ }^{350}$ See: Ogilvie, "After the Charter", supra note 311 at 234: "[T] he Court did not meet the challenge of the case to develop a more urbane conception of pluralism to incorporate greater religious expression."
} 
interesting to apply the Court's reconciliation analysis to an equality rights versus freedom of religion case where there was concrete evidence of discrimination but an equally strong right to freedom of religion in the public sphere, such as Ross.

Iacobucci J highlighted the possibility that the Dagenais framework for rights reconciliation could involve an internal scoping of the freedom of religion right some years prior to the Trinity Western judgment. In his joint judgment with Major J in B.(R)., his Honour adopted an 'analytical approach' to the rights conflict issue, which involved categorizing the religious freedom right as not including "the imposition upon a child of religious practices which threaten the safety, health or life of the child." 351 This approach avoided the "necessity' for a clash of rights, which therefore avoided the requirement for a section 1 analysis, however it also imposed internal limitations on the right, arguably replacing the proportionality and minimal impairment elements of the Oakes test with a priori limitations exercise. This approach was not preferred by the majority in B.(R). with La Forest $\mathrm{J}$ (for the majority) holding that the only balancing provision within the Charter is section 1, and this should be the site of rights balancing. ${ }^{352}$

A key conclusion we can draw from the section 1 analysis in Ross and the scoping of the religious freedom right in Trinity Western is that the Supreme Court of Canada is willing to recognise freedom of religion as an expansive right, but one that can be limited by equality rights (Charter defined or otherwise) where the rights conflict occurs squarely in the public sphere. In Ross, the Court held that the pressing and substantial objective was the promotion of diversity and tolerance within the public school system and the eradication of discrimination, particularly discrimination against minority groups, in the education of children. This definition of the objective with a focus on minority group rights and the nature of public education coloured the Court's findings as to rational objective and minimal impairment and led to the finding that the Inquiry Board's decision was a reasonable limitation under section 1 of the Charter.

Further, in Trinity Western, the Court engaged rights reconciliation principles to scope the religious freedom right as primarily within the private sphere, and only consequently impacting

\footnotetext{
${ }^{351} B(R)$, supra note 279 at para 225; see also: Iacubucci J, supra note 208 at 154.

${ }^{352}$ B. $(R)$, supra note 281 at para 63 . However, La Forest J does note that the Charter makes no provision for directly balancing constitutional rights against one another, even within the terms of section 1.
} 
the public sphere. The private status of Trinity Western, the fact that teaching applicants could choose to attend as opposed to attending a non-religious university, the clear advertisement of the university as having 'Christian ethos and principles' and the application of provincial religious exemption provisions to the Community Standards were persuasive factors in the Court holding that the religious freedom right expressed in the Community Standards document did not reach the threshold required for a section 15 equality claim, nor a claim of discrimination under provincial human rights legislation. ${ }^{353}$

However, the Court was then required to reconcile the rights of students attending Trinity Western (those who identified with the ethos of the Community Standards) with the rights of children in a public education context, given the engagement of teachers in the public school system. In finding that there was no direct evidence of the impact of Trinity's Community Standards on public school students, the Court held that there was no conflict of rights.

Here we come to the issue of rights conflict in terms of the geography of public life: where do equality rights and religious rights fit in the public sphere? For proponents of strong religious freedom, the public sphere is either (a) relatively small, or (b) relatively large, but the public sphere has religious underpinnings that cannot be removed, which justify certain non-religious activities or spaces having elements of the religious in them. (For example, state public schools, prayers at council meetings, Sunday closing legislation). Then there are elements of public/private life that confound this definition, but create real difficulties in terms of public services, for example, access to public health benefits for abortion and contraception, allowing entry to private buildings and commercial enterprises on a non-discriminatory basis, employment of people in non-religious roles by a religious service provider (the janitor at a religious school, the cleaner or orderly in a catholic-owned hospital). This question will be the focus of the next Chapter, in the context of a theoretical analysis of religion in the liberal state.

353 Trinity Western, supra note 214 at para 29. 


\section{CHAPTER 4}

\section{A theoretical perspective of freedom of religion in Australia and Canada}

\section{Introduction}

So far, I have analysed Canadian and Australian legal frameworks that deal with the conflict between equality rights and freedom of religion. I have identified some failures and strengths of different judicial approaches to the rights conflict issue, and I have concluded that the Canadian 'tests' to resolve or reconcile conflicting sets of rights have developed more consistently than the Australian approach, engage with rights limitation in a coherent and certain way and thus give greater guidance to groups and individuals wanting to rely on religious rights or challenge those rights claims. I have also identified those cases raising issues that continue to vex courts, political commentators and rights advocates in terms of the challenge of equality and religion. As I have stated, the challenge for courts and liberal governments in the last decade seems to be recognising the inevitable conflict between sexual orientation equality rights and freedom of religious expression and an increase, rather than decrease, in claims to public space that result in this tension.

My central claim is that neither the Australian approach to rights limitation (presented in Cobaw) nor the reconciliation of rights approach taken by the Supreme Court of Canada in Trinity Western satisfactorily resolve this tension. Arguably, neither does the Court's approach to rights limitation in Ross, however, as I stated in Chapter 3, the Court's application of the section 1 test at least provides a clear, stepped approach to determining a limitation of rights that recognises the central principle of a comprehensive engagement of both sets of Charter rights (and rights embodied in social values, as the equality guarantees were presented in that case). In Ross, however, the Court was asked to adjudicate a rights dispute that was on firmer public ground than in Trinity: a public school teacher, a public education Act that mandated equality as a fundamental value, and anti-Semitic statements made in public with a demonstrated negative consequence on young people in the public education system. As my analysis in the preceding chapters has demonstrated, when the issues of rights adjudication in the public sphere become 
less clear and the effects of religious expression on equality rights are harder to determine, the debate between religious freedom and equality becomes harder to resolve.

It is unsatisfactory for courts to limit their findings about public religious expression to pinpoint subject-matter specific areas of public life and religious doctrine to avoid addressing these as general questions of when and how public religious expression may result in lawful discrimination (such as in Cobaw). Equally, however, the Supreme Court of Canada's assumption in Trinity Western that there was no conflict of rights and therefore no need to resolve this conflict was, in effect, a neat means of avoiding the determination of a difficult, but necessary issue.

I argue that we have to struggle with the fact that, whether we see homophobia and sexual orientation discrimination as a harm on par with anti-Semitic violence in schools, there is no satisfactory way of 'resolving' this type of conflict without rethinking our approach to public religious expression, or to accept that guarantees of equality and non-discrimination must always be qualified by potential exercises of religious freedom. For a range of reasons this would be unsatisfactory. Neither side of the debate is happy with the current shifting ground between equality and religion in the public square. There is also the question of how 'fundamental' a liberal framework can be if it can be breached by religious freedom at will.

What I seek to explore in this chapter, therefore, is the application of a theoretical and philosophical framework to the conflict of rights debate in Australia and Canada, to see whether a theoretical framework and a new scope for religious expression in public, could help decisionmakers to determine rights conflict cases. I have broken this general problem down into two issues that recur with increasing frequency in judicial engagement with the equality-religion issue and that were the focus of all three cases analysed in this work: (a) the question of when and how to protect religious expression in the public square where this expression challenges equality rights and (b) how a state should assess freedom of religion claims: are they still a 'special right' with special status or could we approach religion from a different perspective: as one aspect of a general right to 'ethical independence'? 


\section{Defining 'religion' in the liberal state}

Religious belief is an important aspect of life for many in liberal states despite the apparent rift between liberal values and religious belief. Despite widespread adherence to the 'secularisation theory' throughout the twentieth century, ${ }^{354}$ the relevance of religion and religious groups to western public life has substantially increased over the past 20 years, and religion is now 'back on the liberal agenda'. 355

In his last work published work, Religion Without God, ${ }^{356}$ Ronald Dworkin describes religion as a "deep, distinct, and comprehensive worldview that holds that inherent, objective value permeates everything, that the universe and its creatures are awe-inspiring, that human life has purpose and the universe order." 357 Religious communities make life meaningful for its members and for others in a way that the liberal state cannot, in that they are clear in their promotion of a conception of the good (both in a moral sense and in a personal journey sense). As Jeff SpinnerHalev argues, we cannot simply draw a line between 'bad' and 'good' religious organisations on the basis of their illiberal views or practices. ${ }^{358}$ Religious organisations are strong contributors to liberal society: they encourage people to interact with one another, offer a sense of community and give members valuable opportunities to engage in social and political activities. ${ }^{359}$ For members of these groups, their religious beliefs protect them from negative external influences (this is often seen to be a value by members of the religion, even where this protection might violate principles of autonomy), direct their lives and provide them with social and spiritual engagement. Religious organisations provide important social and charitable service for nonmembers that often supplement or replace those of the state. The Salvation Army, Mission

\footnotetext{
${ }^{354}$ Hugh McLeod, Secularisation in Western Europe 1848 - 1914, (New York, St Martin's Press, 2000); Bruce Kaye, "Is the Emperor wearing the wrong clothes? Human rights and the social good in the context of Australian secularity: theological perspectives" in Paul Babie and Neville Rochow, Freedom of Religion under Bills of Rights (Adelaide, University of Adelaide Press, 2000), pp. 43 - 45.

355 Carolyn Evans, "Introduction" in Peter Cane, Carolyn Evans and Zoe Robinson, supra note 87 at 1.

${ }^{356}$ Ronald Dworkin, Religion Without God (Cambridge: Massachusetts, Harvard University Press, 2013) [“RWG”].

357 Ibid at. 1 .

358 Jeff Spinner-Halev, “Autonomy, Association and Pluralism” in Avagail Einsberg, and Jeff Spinner-Halev eds, Minorities within Minorities (Cambridge, Cambridge University Press 2005) at 165 [“MWM”].

${ }^{359}$ Ibid.
} 
Australia, Anglicare and the Brotherhood of St Lawrence, for example, provide homeless shelters, foster care for children and medical care across Australia and Canada. ${ }^{360}$

Spinner-Halev argues that the splitting of power and authority between different institutions and values strengthens, rather than weakens, civil society. If the only authority relationship existed between the liberal state and individual, without a second layer of customary rules provided by religious bodies, state tyranny and power would "too readily stamp out any non-liberal dissent as dangerous," 361 when in fact it should recognise a plurality of conceptions of the good life. Religious bodies and religious experiences provide forms of community dialogue between religious groups and between the religious and the non-religious, and offer different options for fulfilment and spiritual engagement that is not offered by liberal values. Religious bodies therefore play an important role in liberal society as bellwethers of liberal overreach and overregulation: "both a reflection of liberty and one way in which it is protected." 362 There are justified anxieties expressed by minority culture theorists about liberal theories that reduce religion to an historical oddity and refuse to recognise the value of cultural and religious custom in the liberal state. ${ }^{363}$

I propose that egalitarian liberalism is not necessarily antagonistic to the recognition of religion in public life, but there is an undeniable conflict between public religious expression and equality rights. We cannot reconcile this conflict in all circumstances, but we could do more to recognise common ground between religious and liberal values and to find theoretical points of agreement rather than focusing on the obvious points of difference. Too often, 'religious belief' is presented and received simply as an illiberal viewpoint. This can occur because of the nature of the beliefs at issue (for belief that homosexual activity is sinful or that women should not be accorded equal treatment to men) but also because of the 'special rule' approach to religious beliefs, which requires courts to start from the premise that religious belief must be broadly construed, with a

\footnotetext{
${ }^{360}$ See: John Warhurst, “The Catholic lobby: structures, policy styles and religious networks" (2008) 67 The Australian Journal of Public Administration 2, pp. 213 - 230 at 215; Anna Crabb, "Invoking Religion in Australian Politics", (2009) 44, Australian Journal of Political Science, 2, pp. 259 - 279, at 259.

${ }^{361}$ Spinner-Halev in Einsberg and Spinner-Halev eds, "MWM", supra note 358 at 166.

362 Ibid.

${ }^{363}$ Lucas Swaine, “A Liberalism of Conscience”, in Einsberg and Spinner-Halev "MWM", supra note 358, at 41 66; Spinner-Halev, Surviving Diversity: Religion and Democratic Citizenship (Baltimore, the Johns Hopkins University Press, 2000) p. 20 - 21 ["Surviving Diversity”].
} 
focus on the sincerity of the religious belief (the subjective approach). However, a broader definition of religious belief and a different approach to the concept of 'religious freedom' in the liberal state could provide a different balance between rights, or at least a different justification of the balance reached.

Here, I turn to Dworkin's controversial claims about the nature of religion made in Religion Without God ${ }^{364}$ Dworkin argues for both the broader relevance for religion in the liberal state and limited scope of religious expression. He achieves this by redefining religion as a form of fundamental morality that does not rely on a theistic worldview, but rather insists that there are both atheist and theist versions of deep moral positions that people take and a definition of religion should embrace all of these:

Many millions of people who count themselves as atheists have convictions and experiences similar to and just as profound as those that believers count as religious. They say that though they do not believe in a 'personal god' they nevertheless believe in a 'force' in the universe 'greater than we are'. ${ }^{365}$

Dworkin's definition assumes the significance of a 'religious attitude' in a person's life: one that informs their moral judgements and, to a large degree, how they interact with other people. Dworkin focuses on two aspects of a religious attitude: the intrinsic meaning of human life and the intrinsic beauty and wonder of the natural world. ${ }^{366}$ Dworkin anticipates criticism that his broader concept of religion could be reimagined as a 'conscience vote on everything', by requiring that every religious attitude has an objective value attached to it: a 'feeling' of emotion or faith is not religious without a corresponding appeal to a value judgement. Thus: "[o]ur felt conviction that cruelty is wrong is a conviction that cruelty is really wrong; we cannot have that conviction without thinking that it is objectively true. ${ }^{367}$

I consider this broader concept of religious belief could be supported by the definitions of religion in Australia and Canada, or at least could be cogently argued for. The doctrinal and

\footnotetext{
${ }^{364}$ Dworkin, "RWG”, supra note 356.

$365 \mathrm{Ibid}$, at 2.

${ }^{366}$ Ibid, at $10-11$.

${ }^{367}$ Ibid at 20.
} 
metaphysical elements of the test of 'religion' by the High Court in Australia ${ }^{368}$ deliberately go beyond a theistic concept of religious belief, incorporating an understanding of a governing 'thing, being or principle. ${ }^{369}$ However, the High Court might have had difficulty accepting the fluid boundaries of Dworkin's religious attitude as encompassing a 'religious attitude'. An operative aspect of the test was religious practices or doctrines that guided belief: but then again, in later cases related to freedom of conscience, pacifism was accepted as a valid form of 'belief' without requiring that this be explicitly linked to a religious belief or written doctrine of faith. ${ }^{370}$ Likewise, the Victorian Charter does not discriminate between freedom of religion and freedom of conscience in section 14, preferring to adopt the broad definition of 'belief' set out in Article 18 of the ICCPR that has been clarified to propose an equal freedom of conscience and belief that goes beyond theistic religious belief. ${ }^{371}$

Similarly, the definition of religion and religious belief set out in Big M is sufficiently broad to encompass 'atheist religion'. ${ }^{372}$ Margaret Ogilvie has criticised the definition on precisely these grounds: alleging that Dickson CJ has promoted 'religious secularism' by extending the definition beyond theistic religion, emphasising the personal nature of faith, belief and fundamental values and extending 2(a) to encompass protection of 'freedom from religion'. 373 Indeed, the right in section 2(a) of the Charter encompasses both freedom of religion and freedom from religion, in addition to freedom of conscience.

Dworkin anticipates that some of us, notably theists or scientific atheists (such as Richard Dawkins) $)^{374}$ will not be convinced by his argument about a new definition of religion. Church

\footnotetext{
${ }^{368}$ Church of the New Faith, supra note 36.

369 Ibid.

370 Jehovah's Witnesses Case, supra note 52.

371 The UN Human Rights Committee has clarified that the "right to freedom of thought, conscience and religion (which includes the freedom to hold beliefs) in article 18.1 is far-reaching and profound; it encompasses freedom of thought on all matters, personal conviction and the commitment to religion or belief, whether manifested individually or in community with others. The Committee draws the attention of States parties to the fact that the freedom of thought and the freedom of conscience are protected equally with the freedom of religion and belief." UN Human Rights Committee, General Comment No. 22, supra note 56.

${ }^{372}$ See above for definition of religious freedom, Chapter 2, page 51; Big M, supra note 136.

${ }^{373}$ M.H. Ogilvie, "After the Charter" supra note 311 at 227.

${ }^{374}$ Richard Dawkins, The God Delusion, (Boston, Houghton Mifflin, 2006); see also: Christopher Hitchens, God is Not Great, How Religion Poisons Everything (Toronto, McLelland \& Stewart, 2007).
} 
groups will assert that it devalues theistic beliefs by a mere appeal to conscience based reasoning; while the atheist position rejects the relevance of religious belief to any existential inquiry. Daniel Weinstock makes two substantive critiques of Dworkin's definition of religion that should be addressed: first, that Dworkin assumes a 'Protestant conception of religion' that religion is "fundamentally about belief" and applies to those requirements to act in accordance with one's conscience to give effect to religious beliefs. ${ }^{375}$ Weinstock argues that the problem with Dworkin's definition is that it fails to recognise religious beliefs that place practice, rather than internal belief, "at the core of religious experience." ${ }^{376}$ For these adherents, practice and expression gives effect to their belief and the basis of religious protection does not flow from their internal recognition of their 'belief', but rather their right to practice that belief. Weinstock's second criticism of Dworkin relates to his classification of religion as essentially political in form. Weinstock asserts that Dworkin sidesteps the obligation to answer deep philosophical questions about the 'contours' of the right to religious freedom, but then ends up with a definition of religion that ignores fundamental policy issues about the historical status of theistic religions. ${ }^{377}$

Weinstock accepts Dworkin's procedural position that religion can be given a political form for the purposes of fair regulation. However, he argues that Dworkin's denial of policy considerations about religious belief is arbitrarily applied. ${ }^{378}$ Weinstock rightly notes that theistic religions have "historically been subjected to much greater and more frequent persecution" than other forms of belief, and this may justify a special right approach to religious freedom for theistic religious adherents.

I will consider both of these criticisms in turn. Firstly, the criticism that practice-based faiths should not be primarily grouped with a Protestant concept of 'religion as conscience' can be addressed by the recognition that Dworkin's definition does not seek to limit the concepts of religious thought and practices that can be protected but rather to amplify them. If this is the case, then Weinstock's concern that practice-based faiths would be offered different or less protection

${ }^{375}$ Daniel M. Weinstock, "Religious Freedom Without Religion” (unpublished draft, unpaginated).

${ }^{376}$ Ibid.

377 Ibid.

${ }^{378}$ Ibid. 
should be adequately addressed, although there is still a valid concern that embracing different elements of moral and ethical practices - and giving these the same status as religious practices might devalue the latter. The key response to this question concerns when and how we limit religious expression. It is difficult to see how the category of religiously motivated practices would be harmed by the adoption of a broader definition of religion that encompasses atheistic moral notions, except where these practices are in themselves deeply illiberal or morally indefensible. Weinstock acknowledges this category of religious practice and accepts that sometimes state intervention is needed to prevent practices from generating significant harm. ${ }^{379}$

I agree with Weinstock's condition (as is clear from my argument about the general right to ethical independence supplanting 'special rule' exemptions for religious freedom). There is very little justification for (at least public) religious practices to be exempted from rules about discrimination where they operate to vilify or harm other community members or minority members of their own group. This does not mean, however, that these conceptions of the good life are not fundamentally religious in nature. One can seek to regulate public conduct while also classifying it as a religious attitude that deserves respect in other areas of life.

There are sensitive areas of regulation that deal with those religious practices that are fundamental to a person's conception of the good and what it means to be religious beyond a 'Protestant' conception of faith as internal and conscience driven. However, my premise is that, in liberal states such as Canada and Australia, we should prefer a model of liberalism that endorses a broad view of religion while also advocating a strong liberal framework, as this presents the best balance between freedom of equality and religion in the public sphere. I concede that this position advocates a political response to some difficult policy questions (as does Dworkin's extended definition), and can be criticised as promoting perfectionist liberalism. I would agree with this criticism: it is implicit in any argument that places a high degree of faith in the liberal framework to resolve questions of minority rights. However, I do not see how exempting certain faith-based practices from a general rule or creating a special sub-category of religions that attract separate rules about conduct and behaviour in public life would promote a

${ }^{379}$ Ibid. 
clarity of understanding and shared agreement about the importance of a 'religious attitude' that Dworkin's broad definition promotes.

Turning to Weinstock's second criticism of Dworkin's definition: I agree that it is difficult to accept that one person's belief in vegetarianism or astrology is 'on par with' someone's theistic faith. I also concede that there is something depressingly cultural neutral about Dworkin's presentation of religion in his insistence on equal recognition of different beliefs to achieve political legitimacy for religion. It is also true that some theistic religious groups have suffered great historical disadvantage and may require specific recognition of this treatment in modern society. However, religious groups have also engaged in discriminatory treatment (and going further than that, violent treatment) of other groups on the basis of conflicting beliefs. If the price of social cohesion is the equal recognition of different forms of belief (whether or not these are tied to theistic concepts of religion) then the price is worth it.

I also return to my original point about Dworkin's definition: merely extending a definition of religion for political and legal purposes to other groups should not devalue theistic religion, unless a religious group argues for unlimited freedom to impress their beliefs upon other groups or freedom to discriminate on the basis of religious doctrine in public life. Where these types of claims to religious freedom are made, the reasons for legitimately limiting these practices outweigh historical claims to religious discrimination.

Further, I note that my position in terms of Dworkin's definition is that claims to religious freedom only become the business of the state when they operate in a public forum that is usually state-regulated. I accept Weinstock's criticism about a lack of hierarchy of religious beliefs in relation to more private claims of religious freedom or when those claims are considered in opposition to one another. For example, arguments about home-schooling children are more compelling when put by a closed religious community than when put by a naturist who simply believes that education of children is wrong. I contend, therefore, that Dworkin's position on religion is defendable, and that though there are aspects of his broad definition that religious groups and atheists would reject, these are not unanswerable. What we now need to determine is how to accommodate these beliefs in the 'best form' of liberalism, one that we can readily apply to Australia and Canada. 


\section{Egalitarian liberalism and freedom of religion}

The assertion that Canada and Australia are 'liberal states' within a general definition of liberalism is not controversial, although there are of course different forms of liberalism that are emphasised or diminished by different theoretical approaches. Jeff Spinner-Halev usefully summarises the Rawlsian liberal position as "a doctrine of individual rights and of limited government; the government should be divided so the power of any one branch is circumscribed; liberalism is characterised by the rule of law rather than of men and women. Liberal citizens are equal to one another; they have the same political rights and, one hopes, something close to equality of opportunity." 380

I accept for this analysis that the form of liberalism promoted in Australia and Canada (and that should be promoted) is the 'egalitarian liberalism' preferred by Brian Barry. ${ }^{381}$ In drawing this conclusion, I acknowledge, as does Barry, that there are deliberate limitations to this model and particularly that aspects of 'autonomy liberalism' and 'tolerant liberalism', the former argued for by William Galston ${ }^{382}$ and the latter discussed by Chandran Kukathas and Will Kymlicka fall outside this definition. ${ }^{383}$

For egalitarian liberals, the defining feature of the liberal state is "the principles of equal freedom that underwrite basic liberal institutions: civic equality, freedom of speech and religion, nondiscrimination, as a result of conflicting interests and incompatible beliefs about the social conditions of the good life." ${ }^{384}$ In this form of liberalism, group rights and minority interests are sufficiently protected by a robust right of freedom of association that promotes autonomy and thus generates a state where different conceptions of the good life can flourish, provided these remain within the liberal framework. In terms of the challenge between religious views and the views of the liberal state, Barry argues that the operation of the egalitarian framework, in tension with a strong freedom of association right, strikes a workable balance between minority views and state intervention to protect equality:

\footnotetext{
380 Jeff Spinner-Halev, "Surviving Diversity", supra note 363 at $20-21$.

${ }^{381}$ Brian Barry, Culture and Equality: An Egalitarian Critique of Multiculturalism (Cambridge: Massachusetts, Harvard University Press, 2001).

${ }^{382}$ William A. Galston, The Practice of Liberal Pluralism (Cambridge, Cambridge University Press, 2005). See also: Galston, William, “Two Concepts of Liberalism” 1995105 Ethics pp. 516 - 534 at p. 521.

${ }^{383}$ Barry, supra note 381 at $118-119$.

${ }^{384} \mathrm{Ibid}$, at 122.
} 
[I]t is not the business of the law to regulate conduct as long as it does not violate the constraints imposed by a liberal state for the protection of individuals...They simply deny that the state can legitimately abridge the rights guaranteed by liberal principles in order to penalize beliefs or actions that they view with disapproval... Most liberals rightly also hold that the state should protect people from discrimination on the basis of such things as their religion or sexual orientation. ${ }^{385}$

Egalitarian liberalism is therefore happy to extend tolerance to the internal (and to some extent) external workings of religious groups, provided they agree to conform to the authority of the liberal framework. What separates this argument from toleration liberals is that "what is not up for grabs... is that framework itself." ${ }^{386}$ Here, Barry opposes Kukathas's argument of the moral commons and free group association at all costs, and also refutes the allegation of moral relativism, which he explicitly links with cultural pluralism. This rejection is on the basis that the egalitarian liberal state does uphold core morals and values, rather than merely tolerating a diversity of cultures and norms. Thus, Barry must concede (as he does) that liberal society cannot accept 'deep diversity' in concepts of the good life, because a liberal "holds that there are certain rights against oppression, exploitation and injury to which every single human being is entitled to lay claim, and that appeals to cultural diversity and pluralism under no circumstances trump the value of basic liberal rights. ${ }^{3387}$

In my view, this thesis is strong and representative of Australian and Canadian versions of liberalism. There is no need to go further and assert that such a state does not promote a 'liberal ideal' of the good life. I think it certainly does, and Barry cannot use his equality framework both as the bounds by which diversity and multiculturalism is defined and equally as evidence that the state promotes autonomy of life choices by promoting equality of opportunity. If his adherence to the model is sufficiently strong, then his contention that deep diversity and illiberal policies are not acceptable in liberal societies can presumably be defended without resorting to a claim of neutrality.

\footnotetext{
$385 \mathrm{Ibid}$, at 131.

${ }^{386}$ Ibid, at 131.

${ }^{387} \mathrm{Ibid}$, at $132-133$.
} 
However, Barry promotes the neutrality argument on two grounds. First, he argues that egalitarian liberalism enables a state to (largely) remain neutral as to individual conceptions of the good, as there is a central place for moral and religious toleration and diversity within liberalism, provided this principle "does not violate the constraints imposed by a liberal state for the protection of individuals". ${ }^{388}$ This encompassing of toleration arguably promotes a diverse community where different conceptions of the good life may thrive. ${ }^{389}$ Secondly, Barry rejects the concept of liberalism as requiring autonomy, on the basis that autonomy is merely one of the many choices available to a liberal citizen, and "the inculcation of autonomy by the state is as much of a violation of neutrality between conceptions of the good as would be the inculcation of, say some specific religious doctrine." 390 Thus, in enabling free choice while not compelling the outcome of those choices, the liberal state satisfies the conditions for neutrality.

Proponents of minority rights and autonomy and diversity liberalism argue that this claim to neutrality is unsustainable. ${ }^{391}$ The argument is put that Barry's egalitarian state, in its promotion of core values and the liberal identity of dispute resolution frameworks, does promote a conception of the good life: one infused with the values of equality, fairness and individual autonomy and opposed to illiberal values (as Barry might phrase it elements of 'deep diversity'). Thus, Spinner-Halev accepts Joseph Raz's argument that the neutral liberal state must be impossible, as cultures cannot be "neutral about what sorts of opportunities they supply." 392 Raz particularly challenges the idea that the values of the liberal state could sit comfortably beside those of a religious group that denied female members equal education opportunities, supported underage marriage or actively denied exit rights to group members. ${ }^{393}$

If we accept then, that egalitarian liberalism does promote a conception of the good life, where does this leave us in terms of the treatment of religion? Egalitarian liberalism is criticised as favouring context insensitive universalism, where the different cultural needs of minority groups are subsumed within "radical policies of state-imposed and state-controlled liberal democratic

\footnotetext{
388 Ibid, at 131.

389 Ibid, at 131 .

${ }^{390} \mathrm{Ibid}$, at $122-123$.

391 Spinner-Halev, "Surviving Diversity" supra note 363 at 31; Joseph Raz, The Morality of Freedom (Oxford, Clarendon Press, 1986).

${ }^{392}$ Ibid, Spinner-Halev, at 31.

${ }^{393}$ Ibid.
} 
congruency." 394 This criticism speaks not only to the insensitivities of liberalism to individuals who operate within cultural groups and who are confronted with a 'your culture or your rights' dilemma, but also the failure of egalitarianism to appreciate the value of inter-group cultural difference. $^{395}$

These are valid criticisms of egalitarian liberalism, although I think that they do not give sufficient space to the concept of freedom of association and expression that the model promotes. Freedom of association, when recognised as a core liberal value, protects the "freedom of groups whose norms mandate, among other things, the unequal treatment of men and women." ${ }^{396}$ What is not countenanced, however, is the concept of universal toleration or accommodation of minority group rights where those rights are exercised merely to harm and marginalise members of the group or external individuals: effectively where the norms of the group step beyond cultural practices and breach liberal values. This would engage Barry's warning that cultural difference cannot breach the liberal framework without risking sanction.

\section{Critiques of toleration liberalism}

A response to my arguments for egalitarian liberalism is that we can achieve a workable balance between religious freedom and state equality guarantees in a toleration liberalism framework, where the fundamental value is toleration of all forms of dissent and difference (including illiberal diversity). ${ }^{397}$ Kukathas's position is that the liberal state need not accept or promote the values of minority groups, but that it must accept a rule of freedom of association so broad as to enable groups to freely dissent from all forms of authority if they choose, and to accept the operation of different sovereignties within the one liberal system. "The stance this answer asks individuals, and communities, to adopt in the face of diversity is one of 'live and let live.",398

Kukathas proposes that an inflexible rule of freedom of association (applied equally to all individuals) and voluntary assumption of risk (in terms of membership of groups and the form of

\footnotetext{
${ }^{394}$ Veit Bader, "Associative Democracy and Minorities within Minorities”, in Einsberg and Spinner-Halev, "MWM", supra note 358 at 320.

395 Ibid at $320-321$.

396 Barry, supra note 381 at $127-128$.

${ }^{397}$ Chandran Kukathas, The Liberal Archipelago: A Theory of Diversity and Freedom, (New York, Oxford University Press, 2003) at 23.

${ }^{398} \mathrm{Ibid}$, at 30.
} 
group authority) best determines fairness and freedom in social choices. Kukathas argues that a formal right to exit communities and cultures, including religious groups, is sufficient to justify state non-intervention in any aspect of group life, including their interaction with other groups. ${ }^{399}$ Further, despite the fact that the cost of exit from some groups may be incredibly high (Kukathas refers to the Amish teenager seeking to leave his closed community, but we could think of other examples such as the young Muslim woman with young children or a teenage child bride in a polygamous Christian community) this cost does not affect the degree of freedom that is afforded to the individual by the formal right to exit. ${ }^{400}$ For Kukathas, a minimalist or formal right to exit from religious communities justifies the reverse assumption: that continued membership of an illiberal group demonstrates free consent to all rules and conventions of that community, and freedom of the individual is paramount. ${ }^{401}$

Toleration 'liberalism' promoted by Kukathas (although his position is clearly on the furthest edge of liberalism) grants a strong right to religious freedom through a maximised freedom of association and assumption of risk. There is little, if any, normative role for the liberal state either in promoting a fair procedure of dispute resolution for conflicting community views or as a centre of equality and autonomy-promoting values. In terms of inter-group regulation, Kukathas argues that toleration necessarily leads to the generation of a small, shared moral commons, where groups share some limited ideas of morality applicable to the public square, beyond which their group conceptions of the good thrive in small group contexts. These groups are not, however, subject to any universal normative order. ${ }^{402}$

Barry dismisses this concept as "moral anarchy" ${ }^{403}$ and I think he is correct. ${ }^{404}$ Certainly, in the liberal democracies of Australia and Canada, the public sphere and areas of state regulation cannot fall within this definition, despite both countries historically adopting 'multiculturalism'

\footnotetext{
${ }^{399} \mathrm{Ibid}$, at $105-107$.

${ }^{400} \mathrm{Ibid}$, at 107.

${ }^{401} \mathrm{Ibid}$, at $108-109$.

402 Barry, supra note 381 at 133.

403 Ibid.

${ }^{404} \mathrm{Ibid}$, at 33: Barry notes that much of Kukathas's position on the tolerance of illiberal groups and his rejection of a unified liberal order for morality owes much to anarchist thinking: "the underlying assumption of 'toleration' is moral anarchy There are no overarching norms by which groups and communities can be judged - or at any rate no such judgements can legitimately form a basis for the exercise of a political authority."
} 
as a cultural norm for at least a period of time. ${ }^{405}$ Toleration, within my liberal societies at least, is an important aspect of social policy and political theory, but it operates within a universal liberal framework that applies general moral and ethical rules to public conduct and interactions between groups.

Key to Kukathas's argument about freedom of association is an acceptance that a formal right of exit from religious groups adequately protects the fundamental right to disassociation and individual agency. Kukathas criticises Barry's proposal that it is a "legitimate object of public policy to ensure as far as possible that members of associations have real exit options open to them," ${ }^{406}$ on the basis that it is impossible to determine what costs are 'excessive' and what are associative or internal costs that cannot be quantified and therefore met by the state. ${ }^{407}$ On this level, Kukathas disputes the term 'real' and substitutes 'formal' in relation to exit rights. This nomenclature is central to my critique. Kukathas's position is clearly that, given the fundamental significance of freedom of association, all costs associated with exit must be met by the individual: the state has no role to play. Once we step back from this extreme position however, we see that toleration liberalism must really support a 'genuine' or 'real' right to exit, or its claim to liberalism fails. How can we operate in a society where the core value is toleration of difference and minority rights, where we nevertheless view the state as having to interfere in group activities and inter-group regulation to make exit and association truly free?

As Weinstock has argued, ${ }^{408}$ presenting a formal 'right of exit' as sufficient and fair fails to take into account the complex relationships that people have with groups: both in terms of the type of groups that people join (or are joined to by birth) and the nature of the connection they have with those groups. ${ }^{409}$ It is not sufficient to merely offer a young Muslim woman a formal right to secularism by the operation of neutral state laws. Her family and cultural connections make it very difficult for her to physically leave her home and her religious community. She may well

\footnotetext{
${ }^{405}$ For example, see: Stephen Castles, Multiculturalism, Centre for Multicultural Studies, University of Wollongong, Occasional Paper, 1987, pp. 30; J.W. Berry, Multicultural policy in Canada: A social psychological analysis", 1084, 16, Canadian Journal of Behavioural Science/Revue canadienne des sciences du comportement, pp. 353-370.

${ }^{406}$ Kukathas, supra note 397 at 110, Barry supra note 381 at 150.

$407 \mathrm{Ibid}$, Kukathas, supra note 397 at 110.

${ }^{408}$ Weinstock, "Beyond Exit Rights: Reframing the Debate" in Einsberg and Spinner-Halev eds, MWM, supra note 358 at $227-246$ ["Beyond Exit Rights"].

${ }^{409} \mathrm{Ibid}$, at $234-235$.
} 
not know how to drive, have a bank account or be able to leave her home unless in the company of an older woman or her husband. Clearly, exit rights here need to be offered on different conditions rather than mere 'formal equality' guarantees. State support, in the form of social refuges and community centres with specialist religious expertise, needs to be provided to make the exit right 'real'. However, is even this level of support sufficient to guarantee a genuine right to exit in all circumstances?

To take this point one step further: imagine that children of a fundamentalist Christian group are offered education in a public school system. They are able to be educated at home, but their parents must demonstrate that they are meeting an agreed state curriculum and have standardised testing on this basis. State education, and the curriculum, promotes liberal values. To ensure that these children have a right to exit their religious community (as children or adults), we are enforcing secular educational values and intervening in their education to ensure they are being taught a liberal curriculum. Toleration liberals such as Kukathas would refuse this level of intervention on the basis that it is unconscionable levels of state intervention into minority group activities. However, I contend that it is a necessary level of intervention to meet the bare requirements of a 'genuine' right to exit.

Once we begin to think of freedom of association in the context of exit rights and individual rights to engage with other aspects of liberal society, our commitment to the central premise of toleration liberalism (toleration as a central liberal value) begins to break down. It begins to resemble egalitarian and autonomy liberalism in its degree of state promotion of liberal values and a stronger check on minority group rights. On this basis, I reject it as a valid conception of the liberal state for this discussion.

Barry's view of liberal principles as general or unifying concepts that justify state intervention in the public square is also largely representative of Canada and Australia. In the cases analysed, we see a general concern for non-discriminatory service provision, education and public engagement between groups, and an attempt to reconcile that general position with the 'freedom rights' of religious bodies to adhere to an illiberal perspective. Thus, we see our liberal states attempting to work out the point at which religious claims threaten the 'liberal framework' by unreasonably trenching on its general principles. Within that point however, there is recognition of the value of 
cultural and religious diversity and the right of individuals to pursue their concept of the good life.

\section{Challenges to egalitarian liberalism and a new definition of religion - a libertarian view of religious freedom}

Religious groups and proponents of religious freedom reject the premise of the liberal state that I have described because of its alleged failure to give sufficient recognition to their religious freedom rights. They would also strongly reject Dworkin's broader definition of religion on the basis that it imports concepts of religious pluralism and value-neutrality, and rejects a hierarchy of rights approach that accepts religious freedom as the fundamental or prime right and rejects a hierarchy of religious beliefs within the category of 'religious attitude'.

Members of conservative religious groups in both Australia and Canada align themselves more closely with a libertarian concept of rights that is on all fours with Kukathas's toleration theory than with religious pluralists or multiculturalists. In Australia particularly, 'multiculturalism' is equated with moral relativism and religious pluralism and is viewed as a necessary adjunct to 'liberal' values of equality and tolerance, which is strongly opposed by conservative religious groups. Thus, in his treatise on Christian concerns about liberal concepts of human rights and the introduction of a rights Charter in Australia, Patrick Parkinson objects to anti-discrimination law as the manifestation of an "unpleasant, secularist liberal agenda", one that involves the "coercive imposition of a particular worldview on dissenters, [that is that] anti-discrimination may become the human right that trumps all others." 410

Key to Parkinson's theory is the understanding that libertarian rights such as freedom of religion and expression have a particular historical significance, and are to be preferred as the foundational rights in Australian society. Parkinson objected to the Australian Human Rights Commission's recent Inquiry into Religious Freedom ${ }^{411}$ on the basis that threshold question of 'is there a role for religious voices alongside others in the policy debates of the nation' demonstrated that the Commission naturally weighed the equality rights of 'minority groups' over the

\footnotetext{
${ }^{410}$ Patrick Parkinson, "Christian concerns about a Charter of Rights", in Babie and Rochow, supra note 354 at 142.

${ }^{411}$ Bouma, Cahill, Dellal et al, supra note 88.
} 
individual right of religious liberty and relegated Church positions on rights to the same status as other minority groups. ${ }^{412}$

In Canada, the viewpoint of religious freedom proponents is voiced in similar terms to Australia, despite the marked differences in rights protective frameworks. ${ }^{413}$ In her strong critique of equality rights and section 2(a) jurisprudence under the Charter since Big M, M.H. Ogilvie comments that, for Christian Canadians, the "experiment" of the Charter means the "erasure of the marks of a once predominant Western Christian culture from public spaces and, more recently, isolation in Christian legal ghettos whose boundaries are drawn increasingly narrow by an appellate judiciary creating a brave new world of perfect equality in which a perfect humanity (i.e., Canadians) will reside."414

Ogilvie suggests that the Supreme Court's failure to determine a clear 'trump' of rights in terms of religious freedom over equality rights meant it baulked at drawing a thick line between religious freedom and tolerance of other minority views in public conduct, and thus left Christians unacceptably exposed to complaint and censure in all public activities:

By restricting the exercise of belief to within a religious institution and denying conduct expressive of belief outside, the court thought it had resolved the conundrum. Pity the poor TWU graduates now teaching... Their every word and gesture both in and out of the classroom may be scrutinized for breach of Charter values. ${ }^{415}$

This view of religious freedom takes, at its height, a reading of rights that affords religious freedom the greatest possible scope, and values individual autonomy and expression over the

\footnotetext{
412 Patrick Parkinson, supra note 410 at 145.

${ }^{413}$ I do not deal here with the related question of the legitimacy of judicial review as the determinant of constitutional Charter claims. This is a key issue for opponents of the Charter and proponents of religious freedom however, and is related to the claims asserted in this Chapter. For further discussion on this issue see: Margaret H. Ogilvie, "The Failure of Proportionality Tests to Protect Christian Minorities in Western Democracies: Alberta v Hutterian Brethren of Wilson Colony", 2010, 12, Ecclesiastical Law Journal, pp. 208 - 214; Richard Sigurdson, "Left and Right-Wing Charterphobia in Canada: A Critique of the Critics", 1993, 7 - 8, International Journal of Canadian Studies, 104.

${ }^{414}$ M.H. Ogilvie, “Canadian Conundrum”, 2002, Liberty Magazine, Jan/Feb, online: http://www.libertymagazine.org/article/canadian-conundrum ["Canadian Conundrum"] (last accessed: 2 August 2014).

${ }^{415}$ Ibid.
} 
public toleration of difference. ${ }^{416}$ This view of religious rights in the public square views equality rights (group or individual) as the positive imposition of jarring social values on religious freedom that actively diminish the role of religion within the public square: rather than seeing anti-discrimination as an equal value to accommodate.

Ogilvie assert that the Court's decisions in Ross, Trinity Western and Vriend are the inevitable results of a 'one sided' mechanism for rights resolution (the Charter) that promotes liberal values at the expense of religious liberty. ${ }^{417}$ Likewise, the majority of Christian religious groups in Australia favour the removal or reduction of human rights legislation, on the basis that this is the only way to ensure less 'state interference' in religious beliefs. ${ }^{418}$ In its submission to the federal government, the Alliance Defense Fund (ADF) (an international legal association of Christian lawyers) strongly opposed the consolidation of Australian federal anti-discrimination laws on the basis that countries that have introduced rights Charters (such as Canada) have all experienced a serious reduction in religious freedom and autonomy, in exchange for a new 'liberal' agenda of equality rights, with particular emphasis on the recognition of sexual orientation discrimination. ${ }^{419}$

I have contended that the best view of the liberal state in Canada and Australia is egalitarian liberalism, on the basis that rights protective frameworks (and political theories promoting rights) in those countries most resemble the balance struck between freedom rights and liberal values in the public square. However, what does the application of egalitarian liberalism and a broad definition of religion achieve for cases of rights conflict? I contend that it provides a strong theoretical answer to the religious rights claims put above: that freedom of religion is a foundational and inherently superior right to equality values. This assertion is simply refuted on the basis that both Australia and Canada explicitly recognise freedom of religion, but also present

\footnotetext{
416 Mark Francis, "Human Rights and Libertarians”, (1983), 29, Australian Journal of Politics \& History, 3, pp. 462 472; see also: Swaine, supra note 363.

417 Ogilvie, "Canadian Conundrum", supra note 416: "Originally said to be a shield for liberties, the Canadian Charter of Rights and Freedoms has become a sword for state intrusion into all spheres of life. The public-private distinction has collapsed; personal liberty counts for little."

${ }^{418}$ Bouma, Cahill, Dellal et al, supra note 88 at 40. See also: Anglicare Diocese of Sydney, Submission to the Attorney-General's Department in Response to Consolidation of Commonwealth Anti-Discrimination Laws Discussion Paper, (February 2012) at 9; Babie and Rochow, supra note 356.

${ }^{419}$ Alliance Defense Fund, Consolidation of Commonwealth Anti-Discrimination Laws Discussion Paper, Response of the Allied Defense Fund (Submission, 31 January 2012), at 13.
} 
equality values as fundamental guarantees made by the state to its citizens about tolerance, nondiscrimination and equality before and under the law. Further, in Canada, Charter principles strictly prohibit decision-makers inferring a hierarchy of Charter rights in disputes, and require decision makers to give both equality and freedom of religion rights a broad and purposive reading when they are both engaged.

This addresses the concern that there is a fundamental bias in Supreme Court of Canada reasoning in Charter cases where equality rights are engaged. In Australia, while the principles governing balance of rights cases is much less clear, federal and state Parliaments' intention to protect both sets of rights is demonstrated by the inclusion of freedom of religion rights within human rights legislation. Following the general human rights approach and also the favoured 'plain reading' approach of the Australian courts: it is clear that a reading of rights that assumes a liberal bias against religious freedom is not allowed and neither is an approach that denies the significance of equality rights.

A liberal rights approach to the question of rights hierarchy is that freedom of religious expression is open to all in society- provided that expression does not threaten the liberal framework itself. Barry is on safe ground arguing that 'most liberals' would expect society to introduce anti-discrimination legislation and to require public and private institutions to buy in to those obligations. Most liberals would indeed agree with this while some religious freedom advocates would not. However, few religious freedom advocates who suggest, as Kukathas does, that we should break this liberal framework and endorse authority rule on a group by group basis. Such a suggestion would not only change the fundamental compact between the state and the individual in Australia and Canada, it would also fundamentally alter the set of rights available to each citizen. Most religious freedom proponents generally agree to work within the liberal framework and, on that basis, should logically recognise that equality rights (at least in the public sphere) exist, have legal force, and require recognition. This acceptance of the liberal framework is necessary only (for these purposes) in relation to public expressions of religious belief.

\section{A test for religious expression in public life - ethical independence}

If we accept that equality is a valid social value in Australia and Canada, should religious groups have reason to fear unreasonable limitations on their rights by virtue of the all-encompassing 
nature of their faith? The egalitarian liberal response is only if the exercise of those rights causes unlawful discrimination in places that we recognise as the public square. Courts in both Canada and Australia agree, ${ }^{420}$ reflecting the principle at international law that the private and personal nature of religious belief is virtually unlimited in scope and no limitations are permitted on the freedom of thought and conscience, or on the freedom to have or adopt a religion or belief of one's choice. ${ }^{421}$ It is when religious belief informs or compels actions in public that conflict with equality rights occurs.

The public/private divide is particularly an issue in Australia and Canada where religious organisations and Churches act as employers and service providers in areas that are generally accepted as state services such as health, education, aged care and adoption services, rendering the line between state service and 'religious' service difficult to find and hold. Another problem with this view of religious freedom in the public sphere is that, increasingly, religious organisations operate within areas of public life that are not (traditionally) religious in nature and there is therefore greater risk that equality values will conflict with religious views. ${ }^{422}$

For example, how should we adjudicate the case of the printer who refuses to provide services to a gay and lesbian lobby group on religious grounds $\mathrm{s}^{423}$ or the bed and breakfast who refuses to rent rooms to unmarried or same sex couples? ${ }^{424}$ Should a doctor refuse to provide contraception to a female patient and refuse to refer her to another practitioner, and is it different if they work at a family planning clinic or a general practice? ${ }^{425}$ Should a private Anglican-run aged care home

\footnotetext{
${ }^{420}$ See: Big $M$, supra note 136 , Cobaw, supra note 2.

${ }_{421}$ United Nations Human Rights Committee, UN Declaration on the Elimination of All Forms of Intolerance and of Discrimination Based on Religion or Belief, G.A. A/RES/36/55, U.N. Doc. A/36/684 (1981); Human Rights Committee, General Comment 22, supra note 57.

${ }^{422}$ Rex Adhar and Ian Leigh, Religious Freedom in the Liberal State, (Oxford, Oxford University Press 2005), available online, DOI:10.1093/acprof:oso/9780199606474.003.0006. See also: Hutterian Brethren, supra note 252, per MacLachlin CJ at [90]: "Because religion touches so many facets of daily life... it is inevitable that some religious practices will come into conflict with laws and regulatory programs of general application."

423 Brockie, supra note 132.

${ }^{424}$ Bull \& Bull $v$ Hall and Preddy [2012] EWCA Civ 83.

${ }^{425}$ Manish Krishan, "Doctor on duty 'will not prescribe the birth control pill,' reads sign at Calgary walk-in clinic", National Post, 26 June 2014, online: http://news.nationalpost.com/2014/06/26/doctor-on-duty-will-not-prescribe-thebirth-control-pill-reads-sign-at-calgary-walk-in-clinic/ (last accessed 3 July 2014).
} 
refuse to allow gay couples to register as de facto, thereby requiring them to live in different locations? $?^{426}$

The strength of the egalitarian liberal approach to these cases is that it gives important context to rights disputes about the public expression of religious beliefs and provides theoretical justification for the 'core-periphery' principle, which weakens claims that religious belief (in some religions at least) compels every action of the individual to be religious. Not only does this view undermine the traditional 'hold vs manifest' distinction that Australian Human Rights Commissions have tried to import from international human rights principles, ${ }^{427}$ it also challenges the distinction between public and private conduct that is the basis of antidiscrimination law (in place in every Canadian and Australian jurisdiction) and egalitarian liberalism.

When the private belief of an individual becomes public and has an impact on a group of the public that did not choose to interact with a religious belief or to adopt that belief, then the claim to a 'strong' view of religious freedom must be weaker and the appeal to the liberal framework is stronger. This is reflects the core/periphery proposition, accepted by the Ontario Court of Appeal in Brockie and the Supreme Court of Canada in Chamberlain, ${ }^{428}$ but it goes further than merely drawing a line between 'core' and 'periphery' enjoyment of religious belief, by offering a reason for this distinction that relies on a value judgment of liberal principles in the public square.

\section{Religious accommodation and the 'special rule' approach}

Egalitarian liberals such as Barry accept the concept of religious exemptions and specific religious accommodations, but only where the balance between disadvantage and discrimination demonstrates a high level of need for a special rule approach. This view does not accept that religious exemptions must exist as a general principle and that it must be applied equally to all

\footnotetext{
${ }^{426}$ Gillian Trigg, President of the Australian Human Rights Commission, "Press Release: LGBTI Protection in Aged Care is Necessary" (2013), online: https://www.humanrights.gov.au/news/stories/lgbti-protection-aged-carenecessary-2013 (last accessed 25 March 2014).

${ }^{427}$ For example, the Victorian Commission, submissions, supra note 57 at paras. $53-55$. See also: $C v$ United Kingdom App. No. 10358/83, 37 ECHR Dec \& Rep 142; McFarlane v Relate Avon Ltd [2010] EWCA Civ B1; Hasan and Chaush v Bulgaria (2002) 34 EHRRR 1339, 1358.

${ }^{428}$ Supra note 113.
} 
groups with minority rights claims. ${ }^{429}$ Rather, Barry advocates the equal application of a general law in as many circumstances as possible, and an overt recognition that existing exemptions for religious conduct are "not thin end of the wedge - they are the wedge itself." 430 This view of religious exemptions is wholly interested in religious subject-matter claims, rather than accepting the international human rights approach of the fundamental nature of religious freedom and a consequent promotion of accommodation of religious difference.

This limited role for religious accommodations and exemptions conflicts with Barry's grand statement that freedom of association mandates real equality of cultural choice within the liberal state. It is difficult to see how freedom of association can meaningfully enable cultural and religious adherence if a person cannot express this belief in aspects of their public life that are otherwise legally regulated. Barry requires religious exemptions to satisfy the test that enforcing the uniform rule would have strongly worked to the detriment of religious minorities and resulted in significant disadvantage that outweighed the value of universality. ${ }^{431}$ Barry takes the example of Sikh labourers working on a construction site refusing to wear a safety helmet for religious reasons. Because of a serious issue of race discrimination in employment and education against Sikhs in Britain, the projected disadvantage of applying a safety law without exemption would have had a particularly negative impact on a vulnerable group, whereas the 'rule-and-exemption' approach would have enabled greater job participation by Sikhs. For this reason, rather than because of the sincerity or significance of the religious practice, Barry would allow the exemption.

Barry's examples do not place religious groups in a position of discriminator and so it is difficult to extrapolate his theory beyond a situation where a religious minority appeals to the liberal state as a victim of state uniformity. I surmise, however, that Barry's test for exemptions could equally apply to the case in Cobaw: where he might argue that there was insufficient evidence of significant disadvantage to the religious organisation and religious adherents to warrant public discrimination against gay young people, on this basis, there should be no special rule exempting them from the general prohibition against discrimination.

\footnotetext{
${ }^{429}$ Barry, supra note 381 at 51 .

${ }^{430} \mathrm{Ibid}$.

${ }^{431} \mathrm{Ibid}$, at 62.
} 
Barry's view of religious exceptions and accommodation is at odds with the justificatory tests for exemptions and rights balancing that courts in Australia and Canada currently require as it places much greater emphasis on the 'general liberal equality framework' as opposed to religious freedom. In doing so, it reveals the egalitarian liberal position as being clearly 'value partisan' rather than value neutral. There is no recognition in this principle that freedom of religious expression is an equally valid right in the public square that may challenge liberal principles of equality and anti-discrimination, which is a fundamental basis of Charter rights claims under section 2(a). On these bases, I would treat Barry's test for religious exemptions with caution, if we plan to apply the current balance of religious and equality rights at play in Australia and Canada. However, I contend that we should not, although Barry's subject-matter specific approach to exceptions is not the best approach.

\section{Dworkin's 'general rule' approach - the best answer to a difficult question}

In my discussion above, I have accepted that Dworkin's broader definition of religious belief and religion (encompassing atheist concepts of religion) could be accepted by courts in Australia and Canada without significant changes being made to the scope of the legal definition. This is not to say that all participants in the debate about religious freedom would agree with this definition: it has an unmistakably liberal and political element that reduces religion, on some level, to a policy issue, rather than a matter of faith.

I now turn to his proposal for reinterpreting the test of accommodating religious freedom in public life. I have argued that, despite the Supreme Court of Canada's cogent attempts to avoid a clash of rights in cases such as Trinity Western, we must in fact accept that these circumstances (and other like disputes) involve a conflict of values between religious belief and liberalism. To assert otherwise is rely on a legal fiction of 'reconciliation' which does not satisfy the parties involved nor the broader question of how to manage religious freedom in an anti-discrimination framework. The solution to date has been to exempt religious belief from the general prohibition, creating (effectively) a 'special rule' approach, both in the form of exemptions, but also in the form of arguments about the breadth of religious freedom, an approach that looks at the particular subject-matter of the religious belief and a subjective analysis of the adherence to the religious belief. 
Dworkin advocates approaching religious freedom in a different way, from his starting point that religious belief should be broadly interpreted as including deeply held beliefs about intrinsic value of humanity and nature. ${ }^{432}$ Dworkin then meets the criticism that this broad a definition necessarily means that any claim of conscience would be protected as a valid belief, by asserting that claims should pass a general test of 'ethical independence' in order to be protected. I have dealt with two criticisms of the breadth of Dworkin's definition of 'religion' that is the starting tenet for his concept of 'ethical independence' in the first section of this chapter and I rely on that reasoning in relation to this term also. Dworkin presents ethical independence as one of the two principles of political liberty:

[E]thical independence, means that government must never restrict freedom just because it assumes that one way for people to live their lives - one idea about what lives are most worth living just in themselves - is intrinsically better than another, not because its consequences are better but because people who live that way are better people. ${ }^{433}$

Dworkin suggests that, while 'ethical independence' is a powerful justification for individual action on the basis of ethical belief, it applies as a general rule rather than a 'special rule' or 'special right', with religion as a constituent part of protected ethical views. Dworkin speaks of the current idea of a special right to religious freedom with "its high hurdle of protection and therefore its compelling need for strict limits and careful definition." ${ }^{434}$ The difference between the special right and general approach is that a general 'ethical independence' test focuses on the relationship between the state and citizen actors, and on the ethical claims made by citizens against state regulation or interference in their lives. The special rule approach, by comparison, requires a subject-matter specific approach that analyses the precise nature of the religious claim. $^{435}$

\footnotetext{
${ }^{432}$ Dworkin, RWG, supra note 356 at $146-147$.

${ }^{433} \mathrm{Ibid}$, at 130 .

${ }^{434}$ Ibid at 132. Dworkin's case examples are centred in the United States and his discussion of constitutional protection assumes a liberal state with an establishment clause. This does not mean that his general theory cannot be applied to other liberal frameworks, provided they can meet the various tests and have similar degrees of protection for religious freedom. The argument put in this thesis is that these tests can be met (in general terms) in Australia and Canada.

${ }^{435} \mathrm{Ibid}$, at 133 .
} 
The ethical independence approach is attractive to the modern liberal state because it realises the diversity of ethical beliefs (beyond the bounds of theistic religion) and removes any assumption of hierarchy between religious and non-religious beliefs. It also (so the argument goes) protects religious conviction 'in a more subtle way' than the special right approach by outlawing "any constraint neutral on its face but whose design covertly assumes some direct or indirect subordination" of belief. 436

Dworkin's approach takes a broad view of the state's right to legislate to protect equality of opportunity and non-discrimination, in keeping with the egalitarian liberal principles I discussed in the first part of this chapter. For Dworkin, as for Barry, the general rule, applying principles of liberalism, is that the state can pass laws where there is a need for regulation to promote equality of treatment, safety and good government. ${ }^{437}$ Key to my thesis, Dworkin acknowledges that:

If we deny a special right to free exercise of religious practice, and rely only on the general right to ethical independence, then religions may be forced to restrict their practices so as to obey rational, non-discriminatory laws that do not display less than equal concern for them. ${ }^{438}$

What is meant by 'equal concern'? On its face, this looks like a comparative test between religious beliefs or other ethical claims, and this may be required. However, Dworkin explains that an 'equal concern' test requires the legislature to assess whether any group regards the activity or prohibition as contravening a "sacred duty". ${ }^{439}$ Where a belief meets this high threshold, the state may consider whether equal concern for the group requires a special measure to ensure equal treatment of the group before the law. ${ }^{440}$ Religious groups might, indeed, find this approach to religious claims shocking as Dworkin suggests, ${ }^{441}$ but it would do much to place

\footnotetext{
436 Ibid, at 134.

${ }^{437} \mathrm{Ibid}$, at 136. See also: Dworkin Is Democracy Even Possible Here? (Princeton, Princeton University Press, 2006) at 174 .

438 Ibid "RWG" at 136.

439 Ibid.

${ }^{440}$ This test resembles the 'special measure' or affirmative action protections in anti-discrimination law, which Dworkin discussed first in Taking Rights Seriously (Cambridge: Massachusetts, Harvard University Press, 1977) at $269-288$.

${ }^{441}$ Dworkin, "RWG”, supra note 356 at 136.
} 
different beliefs on an equal footing before the law, while still requiring a degree of flexibility to take into account genuine restrictions and sacred duties inherent in some religions.

As a second position, Dworkin states that exemptions (expressed almost as a second tier 'special rule' underpinning the general right to ethical independence) should be granted on a case by case basis rather than as a general rule, and only where its operation would be managed with no 'significant damage' to the policy in question. ${ }^{442}$ This approach has some similarity with Barry's position on religious exemptions, although Dworkin's approach enables greater scope for the protection of ethical beliefs in the first instance (arguably) and therefore makes a stronger case for case-specific exemptions. Dworkin proposes that the state could provide funding to a Catholic adoption agency that discriminates against same-sex couples, provided that there are many other adoption agencies in the same area that provide the same service on a non-discriminatory basis. However, Dworkin compares this situation of relatively low risk to the example of Native American religious rites that demand the use of peyote. Here, the harm of using an addictive and physically damaging drug is such that state intervention and regulation "seems inevitable and right" and the exemption must necessarily fail, even where use is only restricted to members of that religious community.

I take issue with Dworkin's examples for and against religious exemptions insofar as he limits the concept of 'harm' to fairly extreme physical safety risks. This does not take into account the risks to other individuals outside a religious group where the harm caused by discriminatory conduct is psychological or involves the entrenchment of negative social norms, such as homophobia, racism or sexism. As Justice L'Heureux-Dubé notes in her dissent in Trinity Western, the effects of homophobic treatment, particularly on young people, are profoundly negative and often lead to physical harm and suicide.

It is therefore artificial to limit the state's rights to intervene in cases where the risk of harm is immediate and physical in nature, or to examples where we play moral relativism with conceptions of the good life. To be more specific: I would hope that Dworkin's example of the Catholic agency that may have an exemption and receive state funding despite its discriminatory

${ }^{442}$ Ibid. 
practices would be differently applied if his hypothetical claim considered a discrimination claim by a same-sex couple seeking to adopt a child. The argument that this couple could receive nondiscriminatory treatment at the hands of another adoption agency close by is not compelling if we put it in different terms: imagine that the couple is inter-racial and a religious agency refuses to allow them to adopt a white child. Would Dworkin argue that this agency receive public funding and be exempt from discrimination laws? I would argue that here, as in the peyote example, state intervention to assert equality rights would be seen as 'inevitable and right'.

\section{Public space and religion - specific issues - anti-discrimination and sexual orientation}

Dworkin deals explicitly with sexual and reproductive morality in his analysis of religion in public spaces: arguing that incorporating religious freedom within the broader category of 'ethical independence' necessarily requires different religious views and non-religious views to be treated equally, and to reject the conclusion that one form of identity is preferential to another in public, and even (to a limited extent) in private. Dworkin reasserts the classic distinction between public spaces that need to remain secular; council offices, public streets, courthouses, public services, and private spaces that are religious. His definition of private space for religious belief includes the wearing of religious symbols in public. ${ }^{443}$

In terms of state regulation of sexual 'morality' and identity (including same sex marriage and gender equality in marriage), Dworkin flatly rejects the assumption that these type of state actions can or should be limited by religious arguments. In these cases: "the liberal position becomes mandatory". ${ }^{444}$ Dworkin cites his earlier discussion about the equality rights debate in sexual orientation cases in his work Is Democracy Even Possible Here? ${ }^{445}$ In this earlier work, Dworkin advocates for a special rule approach to questions relating to state positions on the legal status of homosexuality, gay marriage and on reproductive rights issues such as abortion: drawing a distinction between justificatory arguments made on a personal level and a collective level. Thus, laws or positions whereby a majority group is assumed to 'know better' than individual people

\footnotetext{
$443 \mathrm{Ibid}$, at 138 .

${ }^{444} \mathrm{Ibid}$, at 145 .

${ }^{445}$ Dworkin, "Is Democracy Even Possible Here?", supra note 437 at 71.
} 
how they should live their lives are "offensive to liberty and must be condemned as affronts to people's personal responsibility for their own lives." ${ }^{446}$

It is difficult to speculate whether Dworkin would draw such a hard line about sexual orientation discrimination. His examples given about life choices and homosexuality concern state decisions about whether it is criminal to engage in homosexual sex or relationships: a different type of action to religious bodies opposing homosexual activity in public life. However, I think Dworkin would agree with the general position that sexual orientation is one aspect of a person's identity that guides their life choices, is a private matter and is a matter of ethical independence and conscience. On that basis, he would argue for a broad reading of anti-discrimination legislation to protect those ethical claims.

\section{Applying the ethical independence framework in practice}

Can we apply Dworkin's new definition of ethical independence within the liberal frameworks of Australia and Canada? I have demonstrated that the broad definition of religious belief in both jurisdictions can support the religious atheism that Dworkin proposes. However, turning to his argument for a general right of ethical independence, it is clear that in both Canada and Australia the treatment of religious exemptions, tests for religious accommodation and a subjective view of religious freedom involves a subject-matter specific interpretation of religion, and therefore these frameworks begin to resemble the 'special rule' approach that Dworkin rejects. Let us assume, though, that the principle of broad and contextual interpretation of rights (more explicit in Canada, but arguably promoted in the Cobaw decision also) could support the newer definition of 'ethical independence', where the right of religious expression is redefined as one aspect of a general rule of non-intervention in areas of ethical independence.

Dworkin tells us that where religious actions intrude on public life of others by breaching a standard rule, the state must assess the danger of the action against the reasons for state intervention. I would go further here and assume that we could apply the standard rights framework analysis preferred by the Canadian courts: is there a genuine conflict between an ethical position of a group or a person with equality rights? Has this conflict arisen in an area of

${ }^{446} \mathrm{Ibid}$, at 73. 
life where we expect equality rights to operate? Dworkin expresses the 'sacred duty' assessment as being the responsibility of the state, but I surmise that, in most cases, religious bodies would provide evidence that the discriminatory practice meets a 'mandatory or compelling' test (arguably what is intended by the more emotive 'sacred duty' phrase) and therefore should be exempted from the general rule. This accords with the general balance of arguments put for and against religious freedom in rights cases.

If we apply this framework to the cases in this analysis: the 'sacred duty' requirement is similar in substance to the 'necessary to prevent injury to religious sensitivities' test in Cobaw. Here, the majority held that the requirement that members of the Exclusive Brethren Church were not compelled by their religious belief to publicly condemn homosexuals or advocates of homosexuality. The Court held that there was a different form of religious belief that mandated that Church members not engage in homosexual activity, but this did not require Mr. Rowe to discriminate against homosexual young people when accepting bookings for a camp site. The majority took a relatively strict view of the religious doctrines in light of the discriminatory consequence of the religious expression.

In Ross, the Supreme Court of Canada did not evaluate the connection between the type of religious belief held by Mr. Ross and the breach of equality rights: it was sufficient that the belief was genuinely held and was connected to a religious belief. However, if the Court had applied the 'equal concern' test that Dworkin promotes, it would have reached the same conclusion that it did applying the limitations analysis in section 1 of the Charter. There would have been no compelling argument that the Court was treating Christians unfairly or disproportionately to other religions by holding Mr. Ross' public comments against Jews to be discriminatory and sufficient to compel his suspension from teaching. A proponent of another religion would equally have been required to show that their religious belief required a 'sacred duty' to violently condemn members of another religious group, and this would have been very difficult. Further, similar to Dworkin's peyote example, the Supreme Court of Canada's consideration of the risks and harms caused by anti-Semitism in the public school system in Ross is on all fours with the consideration of public risk and harm that would warrant the state criminalising drug use and the forcible use of drug use on minors in religious ceremonies. 
Turning to Trinity Western, the application of Dworkin's test becomes more complicated, partially because this case straddles the public and private spheres that are crucial to determining the limits of liberal intervention in ethical independence. Trinity Western could argue in terms of 'equal concern' that it is entitled to limit activities by its staff and students so as to exclude 'homosexual activity', particularly because there are multiple other universities without such limitations that homosexual students and that students who were offended by such a requirement could attend another institution instead of an avowed Christian university. This echoes Dworkin's example of the Catholic adoption agency.

Further, in terms of the public/private divide, Trinity could argue (as it did) that, as a private institution, it was at least one step removed from the public square and its private status rendered the 'community standards' document a private expression of religious belief and beyond state consideration. The argument put by BCCT on this ground was that it was entitled to infer that graduate teachers who received their degree from Trinity might well not offer a nondiscriminatory, diverse experience for primary and secondary school students in the public system, and on this basis there was a genuine engagement with equality rights. While the Supreme Court of Canada was not persuaded by this argument (without any evidence of discrimination by a graduate), it is possible to meet Dworkin's test in a different way that does not involve resolving the difficult public/private divide question. In contrast to the situation in Cobaw, the Church could reasonably assert that there was a 'sacred duty' for Christians not to practice 'homosexual activities', and to require them to forgo that duty was to breach their ethical independence. Such a submission, coupled with the first argument that students or staff with an issue in relation to the community standards could readily apply to another university, is relatively compelling.

We can therefore answer the rights conflict issues in the cases using Dworkin's framework and reach ethically satisfying results, where there is a clear liberal justification for the courts' decisions, as opposed to a context-specific approach. 


\section{Conclusion}

I have argued that interpretation of rights conflict between freedom of religion and equality rights in Australia and Canada could be improved by revisiting fundamental questions about the type of liberal society in which they arise. With this goal in mind, I have evaluated two different models of liberalism and concluded that, with some caveats, the liberal state in both Australia and Canada fits within the egalitarian liberalism model, particularly in terms of its promotion of liberal values in equality rights guarantees and the value of freedom of association and expression within the context of a liberal framework. I have considered another model for religious freedom within that liberal state: focusing on Ronald Dworkin's proposal of a general right to ethical independence rather that a special right of religious freedom.

Although it would be controversial, I endorse the ethical independence approach to religious freedom. First, it requires the state to justify its intervention or its regulation of ethical issues, which removes pressure from the religious group to demonstrate a compelling 'sacred duty' component or comparative test. The state will not have a strong claim if the conduct is in the private sphere or is private in nature. In the religious cases evaluated here: this is relatively easy to quantify. If a person discriminates in their employment refusing to serve gay people or teaches children that homosexuality is a sin, there is a strong claim for state intervention, applying egalitarian liberal principles and the general test for ethical independence.

Would large religious groups (such as Christian Churches) readily accept this broader definition of ethical independence? The clear answer is no, at least in part on the basis of their claim that freedom of religion is foundational in nature and has a 'special right' claim. I have rejected this premise on the bases set out above: those groups who wish to operate within a liberal framework must accept the existence of equality rights as a competing value in the public sphere. Would other religious groups accept this framework and amended definition? Potentially those groups who favour religious pluralism in liberal society would see inherent value in a definition of ethics removing a reference to religion and religious belief, while still offering protection of religious beliefs. The threshold of 'sacred duty' would be opposed by all groups (I imagine) as too onerous: however if it were equally applied as part of the 'equal concern' test of state action, opposition might be more limited. 
The true value of this approach is that it would give an equal voice to religious and ethical groups in the public square, while still preserving private spaces for cultural and religious activities. Within the egalitarian liberal state that I identify, a broad claim to ethical independence that incorporates religious belief could amplify, rather than limit, the claims put on that basis, answers critiques that a liberal value framework only promotes values of equality of opportunity and nondiscrimination. Further, the test for religious freedom put by Dworkin establishes a clearer test to justify state regulation of religious activities and also state rejection of claims that religious bodies be exempted from equality protections.

The outcomes in the cases identified may not change if we apply the ethical independence test, but the reasoning becomes more clear-cut between liberal values and the application of a liberal framework and the enjoyment of ethical independence by groups and individuals within that framework. It would also enable courts to move beyond complex (and often competing) principles of rights reconciliation that attempt to give equal scope and breadth to both freedom of religion and equality rights, when this is simply not possible. 


\section{CONCLUSION}

In Australia, the role played by anti-discrimination legislation in balancing rights is increasingly a battleground for religious freedom proponents and equality rights advocates, with both sides arguing for a broad conception of 'their' rights, without recognition of the validity of other rights claims. In the absence of a guiding rights document and limited judicial recognition of international legal principles, courts are increasingly challenged to provide satisfying answers to cases of rights conflict.

In this work, I have therefore attempted to compare two constitutional and rights-protective frameworks in countries that are often seen as 'cultural cousins': Australia and Canada. The results of this work demonstrate, however, that the human rights experience in both countries is starkly different. I have not argued that one approach is objectively 'better' or 'worse' than the other, however I have reached the conclusion that there are unacceptable levels of complexity and inconsistency in the Australian approach to rights limitation compared to the more settled principles and tests applied in Canadian cases that demonstrate greater respect for competing rights.

There is clearly a degree of hesitation and uncertainty in Australia about the best form of protection for religious freedom and the question of how to balance this right with principles of equality and non-discrimination. This work demonstrates, however, that similar issues arise in the Canadian context, despite the relative nuance and sophistication of rights frameworks that have been applied to resolve these issues. Much of the analysis in this thesis is not particularly new: particularly the analysis relating to the different tests for rights limitation and reconciliation in Canadian jurisprudence. For the benefit of a comparative study, I have recited foundational Charter principles that would otherwise be redundant in a political theory analysis of rights protection in Canada. However, these were necessary inclusions to demonstrate the relative similarities (few) and differences (many) between the Canadian and Australian approaches to religious freedom and equality rights and to highlight points of intersection between the two approaches. 
Overall, I have argued that the Canadian 'tests' for resolving rights conflict are to be preferred to the statutory interpretation model favoured in Australia, although there are significant political and constitutional hurdles that stand in the way of the adoption of these tests or principles in Australia. However, I have also scrutinised the Oakes test for rights limitation and the Dagenais framework for 'reconciling' a conflict of rights and concluded that, in some respects, the differences between these approaches is artificial. However, the application of the tests in comparative cases (Ross and Trinity Western) indicates that both tests are a laudable attempt by the judiciary to give full effect to governing principles of rights balancing: being the significance of social context, the rejection of a hierarchy of rights approach, the requirement that rights not be weighed in the abstract and that both rights be given as broad a reading as possible.

In the second section of this thesis, I have argued that there is a deeper, foundational dispute about the role of religion within liberal societies that requires discussion as a 'first step' to determining a balance between religion and equality. I have claimed that this dispute can be characterised as social or political disagreement about the type of liberal society that we live inand wish to live in. To refer again to one of my case examples: for a gay student at Trinity Western, there is no other way of interpreting the Supreme Court of Canada's decision other than their right to equal treatment in education and employment was trumped by the right of Trinity Western and Christian individuals to profess their religious faith and require others to adhere to their religious practices, despite the Court's finding that there was in fact no 'conflict of rights' to resolve. This is an over-simplification of the Court's finding, however it gets to the heart of the matter. I argue that, where religion and equality rights conflict in public space (and in those difficult grey areas of public/private space, such as private education facilities), there is no meaningful way to 'fix the problem' without recognising the reality that one set of rights must trump another.

I have suggested that, if any solution is to be found to the conflict between religion and equality rights, it requires a fundamental discussion about the role of equality, faith and religion in our societies, and this in turn is a theoretical task rather than a purely legal one. The decisions analyzed in this thesis demonstrate that we do not have fundamental agreement yet on the responsibilities and roles for religious duty holders in modern society or on the question of why certain minority groups have more powerful claims against religious freedom than others. And 
while we may never reach a point where we have this agreement, it is vital for social and political stability that we engage with this philosophical debate.

In response to these challenges, I have suggested that we rethink our approach to religious freedom in the egalitarian liberal states to give broader recognition to different 'religious' views that go beyond theistic religion and to prefer a general test of ethical independence in relation to religious expression that eschews a special right or religious exception approach. I have given a full account of my findings and proposals in relation to religion and liberalism in Chapter 4 in the conclusion to that chapter, and will not repeat all of these here.

However, as I warned in the introduction to this thesis, the theoretical analysis I have engaged in has been limited to the category of cases that I have reviewed in Australia and Canada: namely cases where the rights conflict occurs in areas of public life generally subject to state regulation, where the religious body has claimed either an exemption from a general prohibition against discrimination or a broad reading of religious freedom that trumps equality rights, and where the discrimination occurs against non-minority group members. I acknowledge, of course, that there are significant issues about individual rights within illiberal religious groups and the availability of exit rights that might influence my conclusions about the risks of egalitarian liberalism, but these are unfortunately beyond the scope of this work.

I realise that the analysis presented here is merely one small part of a multifaceted issue that affects all liberal societies and that cannot be resolved by a simple appeal to 'think about religion and equality differently'. However, for Australia particularly, this type of careful analysis of rights within the liberal state is a necessary first step to resolving conflicts of rights. 


\section{BIBLIOGRAPHY}

\section{Legislation and extrinsic materials}

\section{Australia}

Age Discrimination Act 2004 (Cth).

Anti-Discrimination Act 1977 (NSW).

Anti-Discrimination Act 1991 (Qld).

Anti-Terrorism Act 2005 (Cth).

Australian Human Rights Commission Act 1986 (Cth).

Charter of Human Rights and Responsibilities Act 2006 (Vic).

Commonwealth of Australia Constitution Act 1900 (Cth).

Disability Discrimination Act 1992 (Cth).

Equal Opportunity Act 1984 (SA).

Equal Opportunity Act 1995 (Vic).

Equal Opportunity Act 2010 (Vic).

Fair Work Act 2009 (Cth).

Human Rights Act 2004 (A.C.T.).

Human Rights and Anti-Discrimination Bill 2012 (Cth).

Judiciary Act 1903 (Cth).

Marriage Act 1961 (Cth).

Racial Discrimination Act 1975 (Cth).

Sex Discrimination Amendment (sexual orientation) Act 2012 (Cth).

Sex Discrimination Act 1984 (Cth).

Victoria, Parliamentary Debates, Legislative Assembly, 4 May 1995, 1254.

\section{Canada}

Bill of Rights Act 1960 SC 1960 c. 44.

Canadian Human Rights Act, RSC, 1985, c H-6.

Canadian Charter of Rights and Freedoms, Part 1 of the Constitution Act, 1982, being Schedule

B to the Canada Act 1982, (UK), 1982, c. 11

Human Rights Code, RSO 1990, c H.19. 


\section{United Kingdom}

Canada Act 1982 (UK).

Human Rights Act 1998 (U.K.).

\section{International Law Sources}

Convention on the Rights of the Child (1989) United Nations, Treaty Series, vol. 1577, p. 3.

International Covenant on Civil and Political Rights (1966), United Nations Treaty Series, vol. 999, p. 171.

International Covenant on Economic, Social and Cultural Rights (1966) United Nations Treaty Series, vol. 993, p. 3.

United Nations Human Rights Committee, General Comment No. 22: The right to freedom of thought, conscience and religion (Art. 18), CCPR/C/21/Rev.1/Add.4 (1994).

United Nations Human Rights Committee, UN Declaration on the Elimination of All Forms of Intolerance and of Discrimination Based on Religion or Belief, G.A. A/RES/36/55, U.N. Doc. A/36/684 (1981).

\section{Jurisprudence}

\section{Australia}

Adelaide Company of Jehovah's Witnesses Inc. v The Commonwealth (1943) 67 CLR 116. Attorney-General for Victoria; Ex reel Black v The Commonwealth (1981) 146 CLR 559. Christian Youth Camps Ltd v Cobaw Community Health Ltd and Victorian Equal Opportunity and Human Rights Commission and Attorney-General for the State of Victoria [2014] VSCA 75. Church of the New Faith v Commissioner of Payroll Tax (Victoria) (1985) 154 CLR 120.

Cobaw Community Health Ltd v Christian Youth Camps Pty Ltd [2010] VCAT 161.

Commissioner of Taxation of the Commonwealth of Australia $v$ Word Investments Limited (2008) 236 CLR 204.

Commonwealth of Australiav The Australian Capital Territory [2013] HCA 55.

IW v City of Perth (1997) 191 CLR 1.

Lifestyle Communities Ltd (No 3) (Anti-Discrimination) [2009] VCAT 1869.

Momcilovic v The Queen (2011) 280 ALR 221.

Nelson v Fish (1990) 92 ALR 187.

Noone v Director of Consumer Affairs Victoria v Operation Smile (Australia) Inc. \& Ors [2012] VSCA 91. 
OV \& OW v Members of The Board of The Wesley Mission Council [2010] NSWCA 155. Qantas Airways Limited v Christie (1998) 193 CLR 280.

Slaveski v Smith \& Anor [2012] VSCA 25.

Teoh v Minister for Immigration and Ethnic Affairs (1995) CLR 273.

Victoria v Commonwealth (1996) 187 CLR 41.

Walker v Baird [1982] AC 491.

Waters v Public Transport Corporation (1991) 173 CLR 349.

Xv Commonwealth (1999) 200 CLR 177.

\section{Canada}

Alberta v Hutterian Brethren of Wilson Colony 2009 SCC 37, [2009] 2 S.C.R. 567.

Andrews v. Law Society of British Columbia [1989] 1 S.C.R. 143, 56 D.L.R. $\left(4^{\text {th }}\right) 1$.

B. (R). v Children's Aid Society of Metropolitan Toronto [1985] 1 S.C.R. 315, 122 D.L.R. (4 $\left.{ }^{\text {th }}\right) 1$.

Brockie v Brillinger (No 2) (2002), 43 C.H.R.R. D/90 (Ont. Supt. Ct).

Bruker v Marcovitz [2007] 3 S.C.R. 607.

Canada (Human Rights Commission of Canada) v Taylor [1990] 3 S.C.R. 892, 75 D.L.R. $\left(4^{\text {th }}\right)$ 577.

Canadian Egg Marketing Agency v. Richardson [1998] 3 S.C.R. 157, 160 D.L.R. (4 $\left.{ }^{\text {th }}\right) 1$.

Chamberlain v. Surrey School District No. 36, 2002 SCC 86, [2002] 4 S.C.R. 710.

Dagenais v Canadian Broadcasting Corporation [1994] 3 S.C.R. 835, 120 D.L.R. $\left(4^{\text {th }}\right) 12$.

Edwards Books \& Art Ltd v R. [1986] 2 S.C.R. 713, 35 D.L.R. (4 $\left.{ }^{\text {th }}\right) 1$.

EGALE Canada Inc. v Canada (Attorney-General) (2003) 225 D.L.R. (4 $\left.{ }^{\text {th }}\right) 472$.

Halpern v Canada (Attorney-General) (2003) 65 O.R. $\left(3^{\text {rd }}\right) 225$ D.L.R. $\left(4^{\text {th }}\right) 529$.

Hendricks v Quebec (Procureur General) [2002] R.J.Q. 2506 (Supt. Ct).

Hutterian Brethren of Wilson Colony v Alberta [2007] A.J. No. 518.

MacKay v Manitoba [1989] 2 S.C.R. 357, 61 D.L.R. $\left(4^{\text {th }}\right) 385$.

Marriage Commissioners Appointed Under The Marriage Act (Re), 2011 SKCA 3.

Ontario Human Rights Commission v Brillinger (2002) 222 DLR ( $\left.4^{\text {th }}\right) 174$.

Simpsons-Sears Ltd v. Ontario (Human Rights Commission) [1985] 2 S.C.R. 536, 23 D.L.R. $\left(4^{\text {th }}\right)$ 321.

R. v Big M Drug Mart Ltd., [1985] 1 S.C.R. 295, 18 D.L.R. (4 $\left.{ }^{\text {th }}\right) 321$.

$R$ v. Cook [1998] 2 S.C.R. 562, 164 D.L.R. $\left(4^{\text {th }}\right) 1$.

R. v. Crawford [1995] 1 S.C.R. 858. 
$R v$ Creighton [1993] 3 S.C.R. 3, 105 D.L.R. ( $\left.4^{\text {th }}\right) 632$.

R. v. Kapp 2008 SCC 41, [2008] 2 S.C.R. 483.

$R$ v. Keegstra [1990] 3 S.C.R. 697, 61 C.C.C. (3d) 1.

$R$ v. Mills [1999] 3 S.C.R. 668,180 D.L.R. $\left(4^{\text {th }}\right) 1$.

R. v. Mentuck [2001] S.C.J. No. 73.

R v. N.S. 2010 ONCA 670.

$R v$ N.S. 2012 SCC 72.

R. v. Oakes [1986] 1 S.C.R. 103, 26 D.L.R. $\left(4^{\text {th }}\right) 200$.

R. v. Zundel [1992] 2 SCR 73, 95 D.L.R. $\left(4^{\text {th }}\right) 202$.

RJR-MacDonald Inc. v Canada (Attorney-General) [1995] 3 S.C.R. 199, 127 D.L.R. 1.

R.W.D.S.U., Local 580 v Dolphin Delivery Ltd. [1986] 2. S.C.R. 573.

Reference Re Same Sex Marriage, 2004 SCC 79, 246 D.L.R. $\left(4^{\text {th }}\right) 193$.

Rocket v. Royal College of Dental Surgeons of Ontario, [1990] 2 S.C.R. 232, 71 D.L.R. (4 $\left.{ }^{\text {th }}\right) 68$.

Ross $v$ New Brunswick School District No. 15 [1996] 1 S.C.R 825, 133 D.L.R. (4 $\left.{ }^{\text {th }}\right) 1$.

Saskatchewan (Human Rights Commission) v. Whatcott 2013 SCC 11, [2013] 1 SCR 467.

Syndicat Northcrest v Amselem 2004 SCC 47, [2004] 2 S.C.R. 551.

Trinity Western University v. British Columbia College of Teachers 2001 SCC 31, [2001] 1

S.C.R. 772.

Vriend v Alberta [1998] 1 S.C.R. 493, 156 D.L.R. $\left(4^{\text {th }}\right) 385$.

\section{Foreign jurisdictions}

Ahmad v United Kingdom (1981) 4 EHRR 126.

Brown v Board of Education of Topeka, 347 U.S. 483.

Bull \& Bull v Hall and Preddy [2012] EWCA Civ 83.

C v United Kingdom App. No. 10358/83, 37 ECHR Dec \& Rep 142.

Dogru v. France 27058/05 [2008] ECHR 1579.

Hasan and Chaush v Bulgaria (2002) 34 EHRRR 1339, 1358.

McFarlane v Relate Avon Ltd [2010] EWCA Civ B1.

Pichon Sajous v France App. No. 49853/99 (9 October 2001). 


\section{Secondary Material: Monographs}

Adhar Rex and Leigh, Ian. Religious Freedom in the Liberal State (Oxford, Oxford University Press, 2005).

Babie Paul and Rochow, Neil. Freedom of Religion under Bills of Rights (Adelaide, Adelaide University Press, 2012).

Barry, Brian. Culture and Equality: An Egalitarian Critique of Multiculturalism (Cambridge: Massachusetts, Harvard University Press, 2001).

Byrnes, Andrew, Hilary Charlesworth and Gabrielle McKinnon. Bills of Rights in Australia, History, Politics and Law, (Sydney, University of New South Wales Press, 2009).

Campbell, Tom, Jeffrey Goldsworthy, and Adrienne Stone. Protecting rights without a bill of rights, institutional performance and reform in Australia (Aldershot, Ashgate Publishing Limited, 2006).

Cane, Peter, Carolyn Evans and Zoe Robinson eds., Law and Religion in Theoretical and Historical Context, (Sydney, University of New South Wales Press, 2008).

Dawkins, Richard. The God Delusion, (Boston, Houghton Mifflin, 2006).

Dworkin, Ronald. Taking Rights Seriously (Cambridge: Massachusetts, Harvard University Press, 1977).

—_. Is Democracy Even Possible Here? (Princeton, Princeton University Press, 2006).

—. Religion Without God (Cambridge: Massachusetts, Harvard University Press, 2013).

Einsberg, Avagail and Jeff Spinner-Halev eds, Minorities within Minorities (Cambridge, Cambridge University Press 2005).

Evans, Caroline, Australian Bills of Rights: The Law of the Victorian Charter and ACT Human Rights Act (Melbourne, LexisNexis, 2008).

2012) 
Galston, William A. The Practice of Liberal Pluralism (Cambridge: Cambridge University Press, 2005).

Hitchens, Christopher. God is Not Great, How Religion Poisons Everything (Toronto, McLelland \& Stewart, 2007).

Hogg, P.W. Constitutional Law of Canada, $4^{\text {th }}$ ed. (Toronto, Carswell Press, 1997).

Keyzer, Patrick. Principles of Australian Constitutional Law ( $3^{\text {rd }}$ Edition), (Sydney, Lexis Nexis Butterworths, 2010).

Kukathas, Chandran. The Liberal Archipelago: A Theory of Diversity and Freedom, (New York, Oxford University Press, 2003).

McLeod, Hugh. Secularisation in Western Europe 1848 - 1914, (New York, St Martin's Press, 2000).

Mooney Cotter, Anne-Marie. Heaven Forbid: An International Legal Analysis of Religious Discrimination (New York, Ashgate Publishing House, 2006).

Raz, Joseph. The Morality of Freedom (Oxford, Clarendon Press, 1986).

Sharpe, Robert J. and Kent Roach. The Charter of Rights and Freedoms, (Toronto, Irwin Law Inc. 2009).

Spinner-Halev, Jeff. Surviving Diversity: Religion and Democratic Citizenship (Baltimore, the John Hopkins University Press, 2000).

Tremblay Luc. B. and Gregoire C. N. Webber eds, The Limitation of Charter Rights: critical essays on $R v$ Oakes, (Editions Themis, Montreal, 2009).

Tushnet, Mark, Weak Courts, Strong Rights: Judicial Review and Social Welfare Rights in Comparative Constitutional Law (Princeton, Princeton University Press, 2008).

Van Die, Marguerite. Religion and Public Life in Canada - Historical and Comparative Perspectives (Toronto, University of Toronto Press, 2001). 


\section{Secondary Material: Articles}

Beatty, David M. “The Canadian Conception of Equality” (1996) 46, U.T.L.J. 439.

Berry, J.W. Multicultural policy in Canada: A social psychological analysis" (1984) 16 Canadian Journal of Behavioural Science/Revue canadienne des sciences du comportement 353.

Castles, Stephen. "Multiculturalism”, Centre for Multicultural Studies University of Wollongong Occasional Paper (1987) 30.

Crabb, Anna. "Invoking Religion in Australian Politics", (2009) 44, Australian Journal of Political Science, 2, pp. $259-279$, at 259.

Dixon, Rosalind. "The Supreme Court of Canada, Charter Dialogue and Deference" (2009) 47, Osgoode Hall L.J. 235.

Erdos, David. 'Elite 'blockages' and the failure of national Bill of Rights initiatives in Australia: A comparative Westminster analysis" (2008) 46 Commonwealth \& Comparative Politics 3.

Fielding, Alex. "When Rights Collide: Liberalism, Pluralism and Freedom of Religion in Canada" (2008) 13 Appeal 28.

Francis, Mark. "Human Rights and Libertarians" (1983) 29 Australian Journal of Politics \& History 462.

Galston, Phillip. “Two Concepts of Liberalism”, (1995) 105, Ethics 516.

Hogg Peter W. and Allison A. Bushell. "The Charter Dialogue Between Courts and Legislatures (Or Perhaps the Charter of Rights isn't Such a Bad Thing After All)" (1997) 35 Osgoode Hall L.J. 75.

Hogg, Peter W., Allison A. Bushell-Thornton and Wade K. Wright, "Charter Dialogue Revisited - Or 'Much Ado About Metaphors” (2007) 45 Osgoode Hall L.J. 1.

The Honourable Justice Frank Iacobucci, 'Reconciling Rights' - The Supreme Court of Canada's Approach to Competing Charter Rights" (2003) 20 S.C.L.R. (2d) 137.

Kaye, Bruce. “An Australian Definition of Religion” (1991) 14 U.NSW. L.J. 331. Martin, Sheilah. "Balancing Individual Rights to Equality and Social Goals" (2001) Can. Bar. Rev. 299.

Mathen, Carissima. "What Religious Freedom Jurisprudence Reveals About Equality", [2008 2009] J.L \& Equal. 163.

Ogilvie, M.H. "After the Charter: Religious Free Expression and Other Legal Fictions in Canada" 20022 Oxford U. Comm. L.J 219. 
. "The Failure of Proportionality Tests to Protect Christian Minorities in Western Democracies: Alberta v Hutterian Brethren of Wilson Colony" (2010) 12 Ecclesiastical Law Journal 208.

_. "Canadian Conundrum" (2002) Liberty Magazine, Jan/Feb, online:

http://www.libertymagazine.org/article/canadian-conundrum (last accessed 8 August 2014).

Roache, Kent. "Constitutional and Common Law Dialogues Between the Supreme Court and Canadian Legislatures" (2001) 80, Can. Bar Rev. 481.

Sigurdson, Richard "Left and Right-Wing Charterphobia in Canada: A Critique of the Critics" (1993) 7 - 8 International Journal of Canadian Studies 104.

Tobin, John. "Should discrimination in Victoria's public schools be protected: using the Victorian Charter of Human Rights and Responsibilities to achieve the right balance" (2010) 16 MonashULawRw 36(2) online:

http://www.austlii.edu.au/au/journals/MonashULawRw/2010/16.html

Warhurst, John. "The Catholic lobby: structures, policy styles and religious networks" (2008) 67 the Australian Journal of Public Administration 213.

—. "Religion and politics in the Howard decade", (2007) 42, Australian Journal of Political Science 19.

Weinstock, Daniel M. "Freedom of Religion Without Religion” (2014) (unpublished draft).

Williams, George. "The Victorian Charter of Human Rights and Responsibilities: Origins and Scope" (2006) 30 Melb. U.L.Rev. 880.

Wintermute, Robert. "Religion vs. Sexual Orientation: A Clash of Human Rights?” (2002) 1 J.L. \& Equal. 125.

\section{Secondary Materials: Reports and Submissions}

Alliance Defense Fund. Consolidation of Commonwealth Anti-Discrimination Laws Discussion Paper, Response of the Allied Defense Fund (31 January 2012).

The Australian Christian Lobby, Submission to the federal Attorney-General's Department: opposition to consolidation of federal anti-discrimination Acts, (1 February 2012).

Australian Council of Human Rights Agencies. Submission: Consolidation of Commonwealth Anti-Discrimination Laws (1 February 2012).

Anglicare Diocese of Sydney. Submission to the Attorney-General's Department in Response to Consolidation of Commonwealth Anti-Discrimination Laws Discussion Paper, (1 February 2012). 
Australian Human Rights Commission, Article 18: Freedom of religion and belief, Report (1998).

.The Human Rights and Equal Opportunity Commission Act 1986 (Cth)- it's application to religious freedom and the right to non-discrimination in employment, Information Paper (8 March 2006).

—. A Human Rights Guide to Australia's Counter-Terrorism Laws, (March 2008).

. Racism, It Stops With Me: the National Anti-Racism Strategy One year on-Report and Action Plan (2012).

. Submission to the Commonwealth Attorney-General's Department - Consolidation Project (1 February 2012).

Bouma, Gary Desomd Cahill, Hass Dellal et al for the Australian Human Rights Commission, Freedom of religion and belief in $21^{\text {st }}$ Century Australia (Final Report) (2011).

Canadian Human Rights Reporter, Human Rights Law Primer: Human Rights Law Basics, online: http://www.cdn-hr-reporter.ca/content/human-rights-law-basics.

Coalition Senators, Minority Report for the Australian Senate Legislative and Constitutional Affairs Committee, Minority Report: Human Rights and Anti-Discrimination Bill 2012 (exposure draft) (December 2012).

International Commission of Jurists, Amicus Curiae Submissions, Christian Youth Camps Ltd v Cobaw Community Health Ltd ((SAPC I 2010 0143) (17 August 2012).

Majority Report for the Australian Senate Legislative and Constitutional Affairs Committee: Majority Report: Human Rights and Anti-Discrimination Bill 2012 (exposure draft) (December 2012).

Ontario Human Rights Commission, Policy on Competing Human Rights (2010) online: http://www.ohrc.on.ca/en/policy-competing-human-rights.

Scrutiny of Acts and Regulations Committee, Victorian Parliament, Final Report concerning Exceptions and Exemptions in the Equal Opportunity Act 1995 (26 October 2009).

South Australia Equal Opportunity Commission, Submission to the Australian Human Rights Commission's Submission to the Australian Human Rights Commission Inquiry - Freedom of Religion and Belief in the 21st Century (27 February 2009).

Victorian Human Rights and Equal Opportunity Commission, Submissions for the Second Respondent in the matter of Christian Youth Camps ltd v Cobaw Community Health Ltd and the Victorian Equal Opportunity and Human Rights Commission (SAPC I 2010 0143) (12 June 2012). 
_. Reporting Racism, What you Say Matters - Interim Report (May 2013).

Walker, Julian (Parliamentary Information and Research Service). Canadian Anti-Hate Laws and Freedom of Expression, Background Paper 2010-31-E, 1 September 2010 (revised 27 March 2013).

\section{Secondary Materials: Other Sources}

Bolt, Andrew. "Marcia Langton's vilification: no law against this kind of abuse" Herald Sun online (11 March 2004) online:

http://blogs.news.com.au/heraldsun/andrewbolt/index.php/heraldsun/comments/marcia langton $\underline{\text { s vilification no law against this kind of abuse/ }}$

His Honour Chief Justice French, "The Common Law and the Protection of Human Rights", Speech to the Anglo Australasian Lawyers Society (4 September 2009).

Fyfe, Melissa. "Government bows to religious right" The Age 27 (September 2009) online: http://www.theage.com.au/national/government-bows-to-religious-right-20090926-g76u.html.

Hurst, Daniel. "Discrimination Laws go back to the drawing board", Sydney Morning Herald (20 March 2013) online: http://www.smh.com.au/opinion/political-news/discrimination-laws-goback-to-the-drawing-board-20130320-2genj.html.

Krishan, Manish. 'Doctor on duty 'will not prescribe the birth control pill,' reads sign at Calgary walk-in clinic" National Post (26 June 2014) online:

http://news.nationalpost.com/2014/06/26/doctor-on-duty-will-not-prescribe-the-birth-controlpill-reads-sign-at-calgary-walk-in-clinic/.

Nekvapil, Emrys and Anna Brown for the Human Rights Law Centre, "Case Note: Christian Youth Camp's refusal of booking request to same-sex attracted youths was unlawful discrimination" Case Comment (16 April 2014) online: http://hrlc.org.au/christian-youthcamps-refusal-of-booking-request-to-same-sex-attracted-youths-was-unlawful-discrimination (last accessed: 8 August 2014).

Towers, Katherine “Appeal to clarify religious standing”, The Australian 23 May 2014, online: http://www.theaustralian.com.au/business/legal-affairs/appeal-to-clarify-religiousstanding/story-e6frg97x-1226927433470?nk=fbfeb6feac38bb1971bcf0d33bd01846

Trigg, Gillian. "LGBTI Protection in Aged Care is Necessary" Press Release, President of the Australian Human Rights Commission (December 2013) online: https://www.humanrights.gov.au/news/stories/lgbti-protection-aged-care-necessary-2013. 